\title{
PROBLEMS \\ OF THE ENVIRONMENTAL LAW THEORY
}

Collective monograph

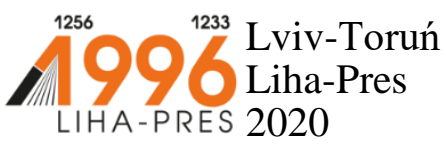




\section{Reviewers:}

Prof. dr hab. Sabina Grabowska, Uniwersytet Rzeszowski / University of Rzeszow (Republic of Poland);

Prof. dr hab. Joanna Marszalek-Kawa, Uniwersytet Mikotaja Kopernika w Toruniu / Nicolaus Copernicus University (Republic of Poland).

Problems of the environmental law theory : collective monograph / V. Kostytsky, A. P. Getman, H. V. Anisimova, Y. A. Hetman, etc. ; edited by Prof. V. Kostytsky. - Lviv-Torun : Liha-Pres, 2020. - $112 \mathrm{p}$.

ISBN 978-966-397-195-7

Liha-Pres is an international publishing house which belongs to the category "C" according to the classification of Research School for Socio-Economic and Natural Sciences of the Environment (SENSE) [isn: 3943, 1705, 1704, 1703, 1702, 1701; prefixMetCode: 978966397]. Official website www.sense.nl. 


\section{CONTENTS}

INTRODUCTION

1

SOCIOLOGICAL AND LEGAL PROBLEMS

OF FORMATION OF ECOLOGICAL STATE

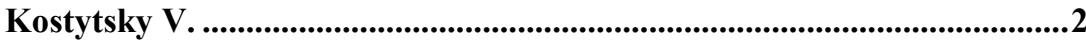

CONTENT OF HUMAN RIGHT TO FAVORABLE

ENVIRONMENT IN GENERAL INTERNATIONAL LAW

Getman A. P., Shchokin Y. V., Hetman Y. A.

IMPACT OF THE ENVIRONMENTAL LAW DOCTRINE

ON THE DEVELOPMENT OF THE STATE

ENVIRONMENTAL POLICY AND LAWS

Anisimova H. V.

AN OVERVIEW OF THE METHODOLOGICAL

APPROACHES TO RESEARCH OF ENVIRONMENTAL

LAW AND LEGISLATION

Sydor V. D., Kostytska I. O. 


\section{INTRODUCTION}

Global development the environmental problems of social life are objectively sidelined by the pressure of the world war unfolding and regional military conflicts, which have also captured our state, terrorism, ethnic resettlement, economic wars, with which modern states are often unable to cope. At the same time, today our civilization does not have a more efficient institute for solving environmental problems than the state and international organizations. Hence, for a long time the state will remain the most effective of the existing models of regulation of social processes, including, above all, relations in the field of protection and management of natural resources.

Philosophers, natural scientists and ecologists connect the most optimistic ideas about character of interaction between society and nature. Also during the last times the betterment of ecological situation was seen in liquidation of the dominant influence of governmental departments, denationalization of economy, granting of valuable sovereignty to the republics, building of the effective legal mechanism of regulation of interaction between society and nature.

Hence we can integrate the conceptions and paradigms which preceded the establishment of system of legal regulation of environmental protection and consider them more detailed.

The modern state asserts its right to "modernity", in particular, through a transformation of its functional component. Such transformation occurs through the separation of new functions of the state, which were not at all inherent in the previous stages of state development, including the ecological function: the state assumes the responsibility for preserving the society itself as a certain socio and cultural integrity, as a habitat for human beings, which, in particular, includes environmental monitoring.

So, today, against the background of global challenges, there is a problem of finding new opportunities in the activity of the state aimed at environmental protection, which should be based on the relevant theoretical and methodological results of scientific dissertations in the field of law-making, implementation of law, modeling of the state. Some of these problems are reflected in the proposed book, which deals with the problems of the theory of environmental and natural resource law, the protection of environmental rights and freedoms of man, the possibility of building an ecological state based on the rule of law.

Prof. Vasyl Kostytsky 
DOI https://doi.org/10.36059/978-966-397-195-7/2-21

\section{SOCIOLOGICAL AND LEGAL PROBLEMS OF FORMATION OF ECOLOGICAL STATE}

\section{Kostytsky V.}

\section{INTRODUCTION}

The modern American and European state, which in Ukraine was fairly called "civilized", is essentially a liberal state, including Ukraine, which was incorporated into the essence of the state and the model of government by the parents of the Constitution of Ukraine in 1996, including the author of this article ${ }^{1}$. So far as, the content of the liberal model of the state, which is put into the Constitution of Ukraine as well, involves a number of important factors, in particular, the rule of law, the primacy of human rights and freedoms, proclaimed the highest social value. Here we also have the restriction of the state by law: the content and direction of the state's activity determine the human rights and freedoms (Article 3 of the Constitution of Ukraine), bodies of state power and bodies of local self-government, their officials are obliged to act only on the basis, within the limits of authority and in a way, stipulated by the Constitution and laws (Article 19 of the Constitution of Ukraine).

As a theoretical and methodological substantiation of what model of the state to replace the post-industrial state in the new world order, the advisability of combining the strengthening of state functions and the need to preserve liberal human rights and freedoms against the background of global environmental challenges, creation of an ecological state.

\section{Problems of the modern state: liberalism and the organization of state power}

Today, the modern state of European-American civilization faces challenges that are almost unrealistic to realize within the traditional framework of a liberal state. It is an issue of environmental protection, ensuring human rights in a favorable environment and avoiding a global

${ }^{1}$ Kostysky V.V. Ecology of Transition: Law, State, Economy (Economic and Legal Mechanism of Environmental Protection in Ukraine) / V.V. Kostysky; Institute for Legislative Predictions and Legal Expertise. - K.: USSB SME Eusmeu, (Series "Ecological Library"; № 5) (Library of the magazine "Small and Medium Business. - 2003. - 772 p. 
ecological disaster, combating poverty, combating terrorism, harmonizing the interests of the state and society, and the interests of the participants in mass transfers to the European Union from the countries of North Africa and the Middle East. For Ukraine, the question of choosing the optimal model of the state is complicated by the problems of the transition period, including external aggression and the loss of control over the part of the sovereign territory, the need for the reform of the administrative and territorial system in order to eliminate the remnants of the administrativecommand system, raw material orientation of the economy, prosperity of corruption, imbalance between the branches of power and frequent political crises, incompleteness of the structuring of civil society and party building, and others.

Therefore, the following question emerges: what model of the state should replace the legal state without losing its value gains, such as the rule of law, the distribution of power, the guarantee of human and civil rights and freedoms. The answer to this question is the theoretical and methodological justification of certain changes in the Constitution of Ukraine, which is today the Social Contract between the Ukrainian people on human and civil rights and freedoms and on the model of state power, as well as an agreement between civil society and the state on mutual rights and obligations, on which the state becomes a service of the people, and the understanding of the essence, tasks and functions of the state, which should combine liberal values with the strengthening of state interference in the sphere of public life associated with the safety of society and human.

The decision of this issue should take place with the contition of solving a number of tasks, the first of which we can call the necessity to organize social life on the basis of public-state partnership, built on legal principles.

Law as a social phenomenon is a product created by a society ${ }^{2}$ on the basis of moral laws established by the Almighty, the Supreme Mind. The multitude of law is that this social phenomenon is a bank of human and civil rights and freedoms, a treasury of social values, but it is also the value itself, the property of the spiritual culture of society. Law is expedient, as a system of rules and regulations law is the most perfect regulator of social relations. Finally, law is a means of consolidation and

${ }^{2}$ Kostytsky VV Ecological law as a theological and sociological phenomenon / V. Kostytsky // Ecological law of Ukraine. - 2013. - № 1. - P. 4-12. 
an instrument for the organization and functioning of power, as the institutional capacity of the subject of law and subject of public relations to make their orders obligatory for others.

In the system of power we distinguish the spiritual power, which is based on the Highest Will, the Moral Imperative, which are "placed" in faith and supported by religion. The next levels of government are the power of the people, which is realized by them through the state (state power) and local self-government, the power of capital and the "fourth" power - the power of mass media. The second task consideration of this issue must be deprived from myths and cliches.

Today there are grounds to say that the idea of building the legal state is based on the principle of separation the power, has become an integral part of the national idea in Ukraine through the implementation of its European aspirations, providing "growing" in European and world community, with the help of criterion to treat Ukraine to the list of civilized nations, part of the mentality and outlook of the modern Ukrainian person.

Today, with the expiry of the twenty-two years, the author of these lines, both co-author of the Constitution of Ukraine, resolved on June 28, 1996, has to admit that at that time a methodological mistake was made, which is now the cause of political confrontations and failures in the work of the state apparatus. It is a question of the fact that the principle of modeling of state power in the draft Constitution of Ukraine was based on the principle formulated by John Locke and Charles Montesquieu 280 years ago regarding the division of power into the legislative, executive and judicial, the principle, which now does not cover all functional branches of the state machinery.

At the same time, we as co-authors of the Constitution of Ukraine, did not take into account the following points:

- since the scientific concept of D. Locke and S. Montesquieu, there has been considerable time, when the state apparatus has been significantly improved and complicated;

- in the $17^{\text {th }}-18^{\text {th }}$ centuries, the idea of the division of power was based on the task of not only not so much national sovereignty, but the task of limiting absolute royal power and depriving society of possible monarchy's arbitrariness if he could not or did not want to be wise;

- when preparing the draft of Constitution of Ukraine, its developers did not have enough time to work out the model of local self-government, 
which under the same constitutional requirements is already the authority of the territorial community, has declared property and budget autonomy;

- the level of legitimacy of the President of Ukraine elected by people is the same as that one of the entire Verkhovna Rada, but under his authority the President cannot be assigned to any of the indicated branches of power.

Therefore, when we use the famous Montesquieu formula of dividing power into legislative, executive and judicial, and the media is called the fourth authority, we make several mistakes at once: the media can not be in this list, because it is not a state power. In addition, state power is limited by law. In Ukraine, this is article 3 of the Constitution, which provides that the content and direction of the state determined by human rights and freedoms, the approval of which is the main responsibility of the state, and the state is responsible for his activities to human. Here we also should mention Article 19, according to which the bodies of state power and local self-government, their officials are obliged to act only on the basis, within the limits of authority and in the manner envisaged by the Constitution.

The third task of modeling the modern state is the return of power to the people and the exercise of state and self-government power in the interests of the people. In the end, according to Article 5 of the Constitution of Ukraine, people are the bearer of sovereignty and the only source of power. The power of the people ${ }^{3}$ is exercised by them through the channels of direct democracy (elections, referendum, the right of legislative initiative), as well as by the state through the legislative, judicial, control and oversight, attestation and executive branches of government. Local self-government implements the power of the people through local referendums, territorial councils, their executive bodies and the institution of village, settlement and city mayors, as well as through public self-government bodies - home, street, quarterly committees, parental committees in schools, community councils.

Of course, now we are talking about the power of the people and state and self-governmental power. Other forms of government should be considered in a wider statement only in connection with the legal

\footnotetext{
${ }^{3}$ Kostytsky V.V. Power of the people: seven functional branches of power (Renaissance problems in the theory of law). - Small and Medium Business, 2010. - P. 4-14; the same one: Distribution of power in legal state and social and normative fixing of the idea of freedom and democracy. - Sociology of law. - 2011, № 2. - P. 3-6.
} 
problems that arise in the process of exercising power: the question of the relationship between church and state, registration of religious organizations, church property, capital power is the subject of study in connection with the legal issues of the activities of transnational corporations, guarantees of entrepreneurship, legal issues of the activities of banks and other financial institutions. It should be noted that capital power is often "imperceptible" to law, since it is implemented beyond the law as well: influence on elections, support of political parties, lobbying, influence on higher state power, etc.

The fourth task is to ensure the optimality of power. The balance of rights and the balance between civil society sectors and between civil society and the state is optimal for a person and a normal social life. Such an ideal state, in our opinion, is achieved with the advent of an era of a law-governed state, which manifests itself as a kind of only possible compromise between the etatist state of the past, which exaggerated the society and controlled it up to the interference with private and family life, as well as extreme liberalism, accompanied by manifestations of anarchism, the war in the sectors of the economy, the ohlocratic methods of exercising power and even the abuse of law.

We regard the creation of an optimal model of the institution of power as one of the most important constituents of the Constitution of Ukraine the Social Contract, along with the consolidation of human rights and freedoms and the definition of guarantees for their implementation.

The greatest prosperity the idea of legal state ${ }^{4}$, before they became the property of political and legal practice, acquired in the period of the birth of early capitalist forms of organization of social life. These ideas were reflected in the writings of the Enlightenment authors and representatives of the German classical philosophy,and these ideas were associated with the need to overcome monarchical absolutism, and then, in particular, in France and the United States, there are ideas of limiting power by law, the abandonment of the monarchy and the transition to a republican form of government.

So, according to Russo's imagination, state is governed by a social contract, which serves as the basis of all rights, and its purpose is to establish a common $\operatorname{good}^{5}$. In his writings, we see the prospects for the

\footnotetext{
${ }^{4}$ Kostytsky V.V. The distribution of power in legal state and the social and normative fixing of the idea of freedom and democracy. - Sociology of law. - K., 2011, No. 2. P. 3-6.

${ }^{5}$ History of political and legal studies: Reader for law schools and faculties / Comp. and total ed. Prof. Dr. Dr. East. Sciences G.G. Demidenko. - X : Fact, 1999. - C. 223.
} 
establishment of national sovereignty, the expansion of mechanisms for the exercise of the people's sovereignty, the guarantee of civil liberties, the concept of universal will as the basis for legislative activity, etc ${ }^{6}$.

Close to such an understanding of a state that does not interfere in the life of civil society and has a minimal impact on its other non-state sectors, were the views of I. Kant, which is fairly considered the founder of the doctrine of legal state ${ }^{7}$.

\section{Ecological function as an integral feature of the modern state}

Civil society, as a result of European-American development, is based on pluralism, which is based on the principle of self-determination of the individual, guaranteeing the human and civil rights and freedoms, statepublic partnership.

The existence of ecological law $^{8}$ system and social necessity in the environmental protection require the ecological state function separation.

In legal literature the state functions are the basic directions of its activity directed on solution of the common matters of subjects of society. At the same time realization of some state functions is executed through the activity inside and outside of the country by participating in the international community life. The ecological function requires its separate consideration in the system of functions of state as a political organization of society.

State ecological function came into being not long ago and simultaneously with intensifying of the problem of natural environmental protection. Earlier the question of regulation of nature using and protection was included in the state economic activity and considered as manifestation of its economic function ${ }^{9}$. Worsening of ecological situation, increasing of the role and importance of interaction between society and nature resulted into the necessity of appearance of separate ecological function among other internal state functions.

\footnotetext{
${ }^{6}$ The history of political and legal doctrines of the XVII - XVIII centuries. / Editorial.: Gratsiansky P.S. and others - M.: Science, 1989. - S. 116-129.

${ }^{7}$ The history of political and legal doctrines of the XVII - XVIII centuries. / Editorial.: Gratsiansky P.S. and others - M.: Science, 1989. - P. 198; Sokolov A. Kant and Contemporaneity (concept of legal state in the mirror of comparative law) // Political Reading. - 1995. - № 1. - P. 4; Timoshenko V.I. Legal power: theoretical-historical researches. - K : Naukova Dumka, 1994. - P. 16.

${ }^{8}$ Kostytsky V.V. Environmental Law of Ukraine: [textbook] 1 book. / V. Kostytsky, Drohobych: Circle, 2012. -360 p.

${ }^{9}$ Kostytsky V. Ecological function of the state and economic and legal mechanism of environmental protection // Law of Ukraine. - 2004. - № 1. - P. 147.
} 
At the same time there are other grounds of separation of ecological function from the modern state functions in special scientific literature. Sometimes such grounds are predefined by the environmental protection requirements and quality new social and economic situation, i.e. transition of the world vanguard to the stage of post-industrial or information development with the following processes: increase of demand on the corresponding scientific and information resources, displacement of accents in the means of using of natural resources; transition to the economy of preservation of resources; transfer of all social life to the socalled stable development.

In professor V. Petrov's opinion, the main content of the state ecological function is determined by the following measures:

- detection and evaluation of the natural resources condition and natural environmental protection;

- ecological planning, financing, logistical support;

- drafting of legal norms and realization of control over their compliance;

- establishment of the governmental machinery in the sphere of nature protection and sustainable use of natural resources;

- organizing of ecological monitoring, state control over natural environment condition;

- drafting of the norms and standards concerning natural environment quality;

- organizing and execution of ecological examination of projects, equipment and other measures which influence on the natural environment;

- organizing of research activity on the problems of ecology;

- ecological education, selection and training of personnel;

- organizing of international cooperation in the sphere of natural environmental protection ${ }^{10}$.

It is a short list of those constituent elements which distinguish the state ecological function as its independent and important function.

State ecological function is realized by the appropriate economic, organizational and legal mechanisms. In addition state legal mechanism is the instrument of implementation of ecological legal function as a new and

${ }^{10}$ Petrov V.V. The concept of interaction between society and nature - the scientific basis of environmental law / Methodological problems of law / Ed. M.N. Marchenko. - M : Moscow State University Publishing House, 1994. - P. 138. 
earlier unknown legal function. It is realized side by side with traditional legal functions, such as: political, economic, cultural and educative, etc. Formation and development of legal ecological function is the result of development and deepening of social contradictions between society and nature, understanding of the need and necessity of considerable extension of legal intervention in the regulation of relations in the sphere of environmental protection and using of natural resources.

The purpose of legal ecological function is ensuring of natural environment quality under the conditions of social economic development by legal regulation instruments. This purpose is attained by drafting, adoption and application of legal norms represented the requirements of ecological regularities concerning interaction of society and nature which consolidate the scientifically proved norms of economic influence on the environment ${ }^{11}$.

It is interesting that in one of the latest theoretical legal research concerning analysis of the state functions professor A. Pigolkin included the legal function (or function of freedom and ownership ensuring) and function of communication system formation in the state functions ${ }^{12}$.

In our opinion, the analysis of correlation between all state functions is more efficient and depends on their objects.

Certainly, the ecological function is not permanent concomitant of state organization of society. Moreover, it is possible to ascertain its late appearance as a separate state function only in the second part of the XX century. Till that time this function was fundamental part of state economic function and it was realized as a constituent part of state economic policy. However, today in some special scientific research we can find the environmental protection interpretation as a component part of state social and economic policy ${ }^{13}$.

State ecological function began to separate only for some time past due to the progressing worsening of the natural environment condition of the planet. The modern manufacture development (output of minerals, development of the chemistry, metallurgy, etc.), using of the newest

${ }^{11}$ Petrov V.V. The concept of interaction between society and nature - the scientific basis of environmental law / Methodological problems of law / Ed. M.N. Marchenko. - M : Moscow State University Publishing House, 1994. - P. 138.

${ }^{12}$ Problems of the general theory of law and state. Textbook for universities / Under commonly. ed. V.S. Nersesyan. - M : "Norma", 2001.

${ }^{13}$ Combating environmental crimes. (Criminal and Criminal Investigation). - K : Sciences. opinion, 1994. - P. 9. 
technologies by which human breaks the natural balance that existed during millions of years, appearance of huge amount of wastes including the atomic manufacture wastes do harm the ecosystem and have irreversible consequences. For example, the Chornobyl nuclear disaster in Ukraine was constitutionally recognized as a planetary catastrophe. Therefore, a state more and more actively operates in the sphere of recovery of the broken balance.

This function objectively became general function for all countries. Nowadays many international agreements on the defence of environment (flora, atmospheric air, etc.) were concluded ${ }^{14}$.

So, we can consider the state ecological function both as internal and external. This statement is absolutely fair because of the following reasons:

- intensification of the processes of globalization of ecological problems (sometimes scientists even stress on the fact that humanity has already gone across a limit which detach out planet from ecocatastrophe and now all states have to coordinate their efforts for its warding off);

- unification of values of the modern states with globalization processes which also cover social and political and legal spheres of social life (harmonization of legislation; formation of democratic legal social states; recognizing of legal rule, priority of human rights, democratic development principles, etc. as the indispensable state attributes).

Today we can see a raise of the role and importance of this state function on the example of constitutions adopted in the second part of the $\mathrm{XX}$ century. As a rule, they consolidated the state policy novels in the sphere of environmental protection and defence. Constitutional consolidation of the state ecological function is the first evidence of importance of this state activity direction under the present-day conditions.

During the Soviet times scientists began to distinguish state ecological function. At first it was made by O. Kolbasov and Y. Shemshuchenko ${ }^{15}$. Now it is especially topical function taking into consideration a globalization of ecological problems and only societies which are wellorganized and well-coordinated by the state and which defend the common civilization values.

\footnotetext{
${ }^{14}$ Chirkin V.E. The modern state. - M : International. Relations, 2001. - P. 203.

${ }^{15}$ Kolbasov O.S. Ecology: politics - law. - M : Science, 1976; Shemshuchenko Y.S. Organizational and Legal Issues of Environmental Protection in the USSR. - K : Sciences. opinion. $-1976-276 \mathrm{p}$.
} 
The second argument which confirms a need of the state intervention in the ecology defence process is the branched special legislation as the instrument of solving of ecological problems. At the same time such special legislation should consolidate a system of ecological rights and freedoms of human and citizen as one of the most important constitutional rights and freedoms.

Allocation of considerable budgetary funds for the environmental protection measures is another confirmation of realization of ecological function by the modern state. Specific of the state ecological function realization depends on the conditions of operating of different types and kings of states, their social and economic structure, special features of state national and political regime, civilization development condition.

\section{Ecological function and environmental policy of the state}

State ecological function can be realized only under the conditions of the modern democratic legal social state which has a complex of obligations to society and human, protects ecological rights and freedoms, takes care of the environmental protection by using of special instruments ${ }^{16}$.

The main positions regarding the essence and direction of the state ecological policy of Ukraine are included in the base legislative act on the questions of environmental protection, i.e. in the Law of Ukraine "On protection of the natural environment" dated June, $25^{\text {th }} 1991$. This law stipulates that Ukraine realizes the ecological policy on its territory, directed to the prevention of environment which is safe for life of animate and inorganic natures, defence of human life and health from negative influence of the natural environment pollution, achievement of the harmonious interaction between society and nature, protection, sustainable use and recreation of natural resources.

So, the ecological policy is one of the state activity directions which has corresponding priorities and tasks of social and economic, natural and social character.

We can separate two basic forms of state ecological policy realization, in particular: the ecological policy strategy and ecological policy tactics.

The ecological policy strategy is the course of state ecological policy, aimed at the long-term prospects and solution of the important economic and social tasks, tasks of cultural development, ensuring of state

${ }^{16}$ Muhamet - Irekle A. On the Function of the Rule of Law in Modern Nature Management. Monograph. - M : "NIA-Nature", 2002. - 272 p. 
ecological safety, preservation and increase of its natural potential and national wealth, defence of ecological rights and freedoms of physical and legal entities, increase of national well-being.

Ecological policy strategy (or ecological strategy) includes search of the national economy priority purposes, instruments and methods of their realization on the basis of purport of objective processes and tendencies of the environment condition, changes in environment and peculiarities of its protection which take place in the national and world economy, and taking into account the legal interests of ecological law subjects ${ }^{17}$.

Ecological tactics is a combination of the nearest purposes, tasks, instruments and methods of their achievement for realization of ecological policy strategy under the concrete conditions of the present development.

As a rule, the ecological strategy and ecological tactics measures are realized in legal forms. In particular, ecological policy legal consolidation is realized by the following instruments: determination of principles of domestic and external policy; prognoses and programs of economic and social development of Ukraine and its separate regions; programs of activity of the Cabinet of Ministers of Ukraine; purpose-oriented programmes of economic, scientific and technical and social development and corresponding legislative acts.

In general policy is a special activity on the administration of state and society, organizing and supervisory sphere of society which manage the economic, legal, social, cultural, and religious spheres, etc ${ }^{18}$. The term "policy" comes from Greece and means something state-related. This term takes rise from Aristotle's treatise "Policy" about state, administration and government.

From Aristotle's times and to the end of XIX century policy was considered as a doctrine about state, i.e. state level power. Nowadays there are several fundamental explanations of the term "policy", such as:

1. It is the relations between classes (as relations of consent, enslavement, supremacy, conflict and fight), groups, people (as domestic policy) and states (as external policy).

${ }^{17}$ Tomenko M. The Ukrainian Perspective: Historical and Political Foundations of Modern State Strategy / Political Studies. Issue 2. - K : Ukrainian Perspective Foundation, 1995 - P. 4; Development strategies of Ukraine: challenges of time and choice / E. Bazovkin, A. Belouk, O. Valevsky, et al. - K : NISD, 1994. - 177 p ; Valevsky O.L. State policy in Ukraine: methodology of analysis, strategy, mechanisms of implementation. - K : NISD, 2001. - P. 121-126.

${ }^{18}$ Politology. Textbook / Edited by prof. Kremena V.G., prof. Gorpacha MI - Kharkiv: Unicorn Printing Center, 2001. - 640 p. 
2. It is the supremacy, power and activity that attach the seizure of power and its using.

3. It is practical administration, normalization of social life (from Platon's times it was called as functional approach).

The policy can exist as the following kinds of activity:

- theoretical, intellectual activity which forms the political essence, mode of thinking and mentality;

- practical activity as organizing and control activity, arrival at a decision by the leaders, work with people, exchange of information, government authority operating, etc.

The policy is materialized by the government authority in the legal acts.

Ecological policy as a constituent of policy is a system of measures, aimed at ensuring of the natural environment quality, recreation of natural resources and creation of the proper ecological conditions of human life and practice of realization of these measures.

Ecological policy is a combination of methods and means of influence of state and other political institutes on the "society and nature" system with a purpose to solve its conflicts timely and ensure the favourable environment of existence of human and society at present and in prospect.

Separate scientists determine the ecological policy as an organizing and regulative and control activity of society and state directed to the environmental protection and improvement, ensuring of the normal vital activity and ecological safety of citizens. But this term reflects rather desirable than real things.

Ecological policy as ecological strategy and ecological tactics is a form of realization of the state ecological function. Ecological policy is the expression of forms and methods of realization of state ecological function in the concrete historical conditions by the concrete political systems. Therefore, analysis of ecological platforms of separate political forces and political parties, especially during pre-election company, is very important for evaluation of the ecological policy efficiency. In Ukraine the political parties continue to establish their own ecological priorities which do not have any real character ${ }^{19}$.

Subjects of the ecological policy realization are state, political parties, public organizations as subjects of civil society. State ecological policy

${ }^{19}$ Kostytsky V.V. Political Parties in the System "Civil Society and State" // Law of Ukraine.- 1995. - № 12; Kostytsky Vasyl. State-building processes are components of multiparty development in Ukraine (political and legal analysis). - K., 2002. -60 p. 
will be realized through the state ecological function as a direction of its activity. Some scientists attribute the state ecological function to its internal functions ${ }^{20}$. As state ecological function is the expression, direction of realization of state ecological policy which includes an internal and external policy it is logically to admit that state ecological function is the complex function and it is displayed as external and internal functions of ecological state ${ }^{21}$.

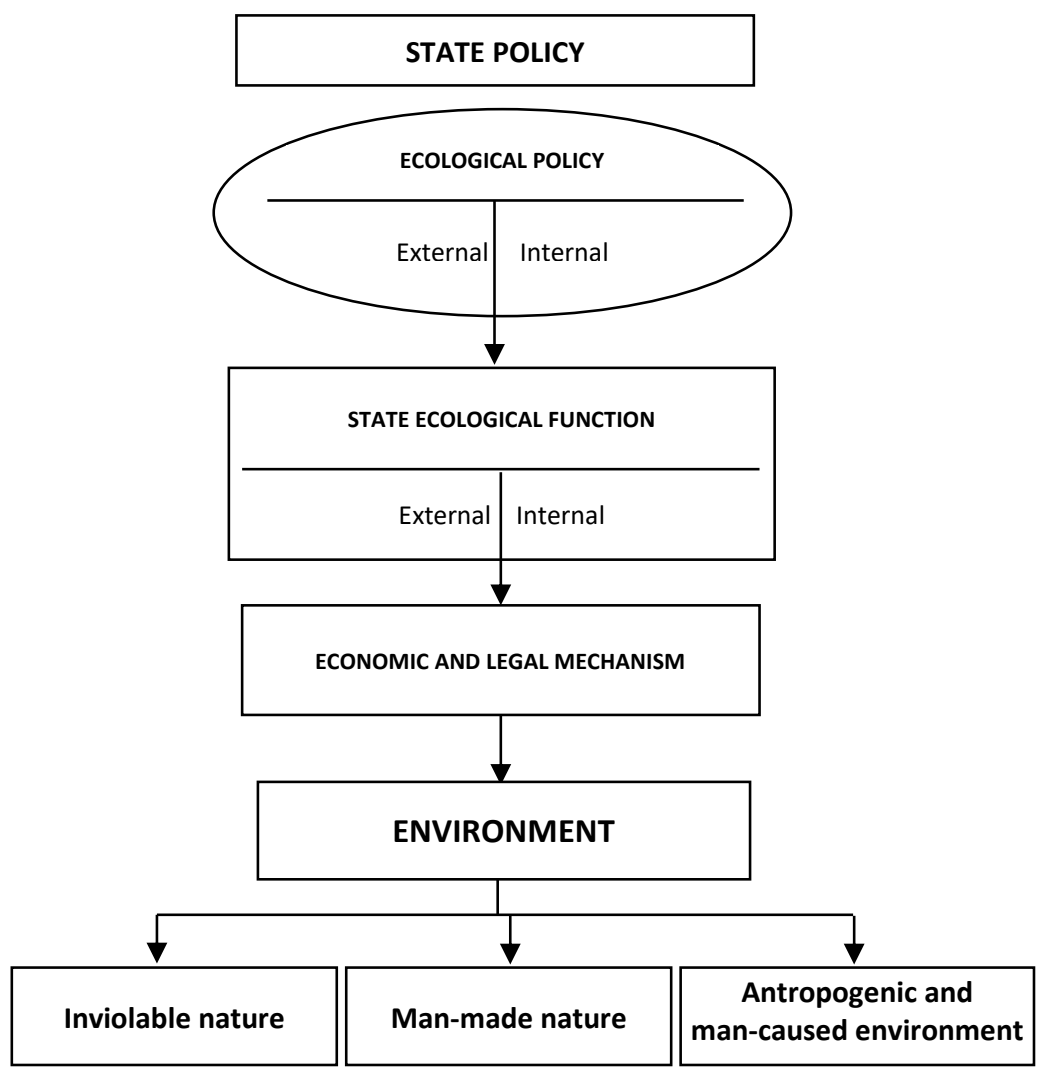

Fig. Mechanism of the state ecological policy realization

${ }^{20}$ General theory of state and law. Academic course in 2 volumes. Volume 1 . Theory of the State / Ed. M.N. Marchenko. - M : "Mirror", 1998. - P. 203-204.

${ }^{21}$ Kostytsky V.V. The modern state is an ecological state: a sociological-legal approach / V.V. Kostytsky // Sociology of Law. - 2018. - № 1-2 (24-25). - P. 102-110. 
State applies various instruments and mechanisms of regulation of economic activity in the sphere of management of nature or realization of ecological policy, purpose-oriented ecological programs and related with them programs of economic and social development. The main means of state regulative influence on the activity of market participants in the field of environmental protection are the following: ecological taxation; licensing; certification and standardization; application of standards and limits; regulation of prices and tariffs; granting of investment, taxation and other privileges; granting of dotations, compensations, purpose-oriented innovations and subsidies.

Terms, volumes, spheres and procedure of application of separate types of instruments of state regulation of economic activity are determined by the legislative acts and programs of economic and social development. Granting and suspension of privileges and advantages in the economic activity of separate categories of market participants are realized according to the laws.

\section{From ecological function to creation of ecological state}

Nowadays realization of the state ecological function foresees solving of strategic and tactical tasks. Strategic tasks of the state ecological strategic policy are considered in the following: preservation and recovery of natural biosphere ecosystems in the necessary extent; ensuring of stable development and environment which is suitable for human vital activity under the condition of the minimized risk of initiation of ecological emergencies.

Obviously, under the conditions of worsening of ecological problem Ukraine has to determine its new state role in this process.

Taking into account the experience of times of independence, we can make a conclusion about necessity in more absolutely and more effective using of the state-legal and organizing and administrative mechanics of the environmental protection ensuring. So, they should newly treat thesis that development of society and all its institutes including state and law is the natural and historic process developed according to the definite objective rules. Of course, in such approach the purposeful formation of state and legal systems according to the preconceived plan seems to be utopian $^{22}$. However, just transfer to the phase of stable civilization development as a quite new form of interaction between society and

\footnotetext{
${ }^{22}$ Spiridonov L.I. State and Law Theory. - M., 1996.
} 
nature and environmental protection foresees the systematic evolutional change of the state and legal mechanism.

In this context the American discoverer T. Hoja's research is quite interesting. He analyzed the methods of market economy in the American and Russian ecological laws and made a conclusion that "among all Western industrially developed countries the USA ecological law is mostly based on the administrative-command methods"23.

After proclaiming of independence of Ukraine Ukrainian scientists, politicians, officials focused their attention on the establishment of economic administration methods in the sphere of environmental protection and using of natural resources taking into account the negative experience of solving of ecological problems in the former Soviet Union.

The effective economical and legal mechanism of the environmental protection based on the interaction of administrative and economic instruments of solving of ecological problems and ensuring of stable development should be in the base of ecological strategy realization under nowadays transitional period conditions.

Modern phase and peculiarities of realization of the state ecological function are characterized by two opposite processes, such as: on the one hand, it is intensification and deepening of globalization processes; on another hand, there are certain tendencies of solving of national ecological problems on account of other states. But domination of the second tendency contravenes the possibility of averting of global ecocatastrophe and ensuring of the effective cooperation in the sphere of state ecological policy.

Ukrainian state needs the long-term transitional period for full value realization of its ecological function. Also the content of this period has no obligatory lie down in the deep social transformations which, obviously, are not entirely predetermined and guaranteed by the internal factors. Thus, in O. Dergachov's opinion, this period can not be a classic period of the "internal concentration", because the ecological function realization is fully impossible under isolation conditions in the modern globalized world. Today the open question on interaction between national and international ones arose in Ukraine in the context of polity strengthening, disclosure of prospects and improvement of the long-term strategy. This

${ }^{23}$ Hoya T. Methods of market economy in American and Russian environmental law // Bulletin of the International University. - The Law Series. - Issue 5. - M., 2001. - P. 152. 
problem becomes more complicated due to the historical lagging of the internal processes from prevalent international tendencies ${ }^{24}$.

The lagging of Ukraine from the progressive Western states in social and economic and political development circumscribes real limits in the state ecological policy realization. As a rule, Ukraine has unequal relations with more powerful partners that treat it only as a potential source of creation of the additional ecological dangers or so-called perspective "disposal tip of Europe".

The international context predetermines the substantial lagging or even falling out of Ukraine from general logic of civilization development and threatens with increase of the relative isolation, final removing to the periphery of such system of international relations which has the paradigm of stable development as its foundation. So, the state role strengthening in the field of ecology is somehow predetermined by the modern configuration of existing system of international relations and the place of Ukraine in it.

At the same time the state role strengthening both inside of the country and in the system of international relations does not means that a burden of transfer to the stable development has to be concentrated on the state without any interaction between state and civil society. In S. Shmidheini opinion, who hold a position of the Head of the Council of entrepreneurs on the questions of stable developmen "it is impossible to realize the stable development conception only by the governmental decisions, because billions of people participate in the manufacture and consumption processes. Governments have to create pre-conditions and conditions of its development" 25 .

While realization of the state ecological function under the conditions of transitional period the role of state administration and regulation will objectively increase.

The state can be called the ecological state if it meets certain criteria, when its functioning is based on certain conditions:

- the Institute for Environmental Rights and Freedoms of Human Rights is materialized in legislation;

- the ecological function of the state and its environmental responsibilities to society and man in accordance with the principle of the rule of law are enshrined in the constitution as a social treaty;

24 Dergachev O. Ukraine in Modern Geopolitical Transformations // Political Thought. - 1998. - № 2. - P.186.

${ }^{25}$ Schmidhaney S. Changing course. Prospects for development and environmental problems: an entrepreneur approach. - M., 1994. 
- environmental law system is developed;

- institutional frameworks have been created to ensure the implementation of the state's ecological function;

- a balanced economic and legal mechanism for environmental protection is formed - there is an independent public control of the society over the implementation of environmental legislation;

- the principle of joint responsibility of the state and society for the future living environment is approved;

- there is a public environmental dialogue;

- the basis of the state environmental policy - the human right to a favorable living environment;

- the ecological and legal culture, which underlies decision-making processes is developed;

- the environmental and legal motivations of the behavior and life of the elite are formed.

\section{CONCLUSIONS}

It can be noted that today we have the reason to speak about the possibility of recognition of Ukraine as an ecological state, which is formed within the framework of the mentioned theoretical and methodological paradigm. In particular, the Constitution of Ukraine enshrines the ecological function of the state, approved the economic and legal mechanism of environmental protection, which implemented the international legal principle "polluter pays". Public organizations have acquired access to participate in determining the state's environmental policy. We have developed advanced environmental legislation that enshrines environmental human rights and freedoms. At their core - the right to environmental safety, guaranteed by Art. 50 of the Constitution of Ukraine. The same model occurs in several other states.

However, in our view, now the right to environmental security must be seen as a manipulation of modern states, driven by their financial capabilities and attempts to find parity between the economic interests of the capital power and the environmental interests of present and future generations. Indeed, the right to environmental safety is based on the obligation of the state to develop, approve and ensure compliance with environmental anthropogenic pollution by entities that do not take into account neither the total effect of the commented pollution, nor the consequences of their long-term impact on human and environment. Hence the need to underpin the State's obligations to civil society for the 
human right to a favorable environment and the principle of the rule of law, which embodies both the recognition of a person of the highest social value and the definition of environmental rights and freedoms, above all, the fundamental human right to favorable environment, which determines the content and orientation of the state.

\section{SUMMARY}

The author once again raises the question of the importance of the formation of an ecological state as a political and legal response of modern civilization to global challenges and environmental threats. The section is dedicated for the first time raises questions about the new role of the state in modern conditions, the state's ability to respond to global challenges using theoretical and legal science and sociology of law as part of his proposed theological and sociological understanding of law. According to the author, to replace the post-industrial state, which is the mechanism maintenance liberal values of society has come a social constitutional state which can maintain democratic values, on the one hand, and find answers to the challenges, on the other hand, provide amplification powerful influence on the developments in society between civil society and state under the constitutional and legal requirements as a social contract. Important here is to find the optimal model of governance on account of author proposed a new vision of functional separation of powers.

\section{REFERENCES}

1. Combating environmental crimes. (Criminal and Criminal Investigation). - K : Sciences. opinion, 1994. - P. 9.

2. Chirkin V.E. The modern state. $-M$ : International. Relations, 2001. - P. 203.

3. Dergachev O. Ukraine in Modern Geopolitical Transformations // Political Thought. - 1998. - № 2. - P. 186.

4. Development strategies of Ukraine: challenges of time and choice / E. Bazovkin, A. Belouk, O. Valevsky, et al. - K : NISD, 1994. - 177 p.

5. History of political and legal studies: Reader for law schools and faculties / Comp. and total ed. Prof. Dr. Dr. East. Sciences G.G. Demidenko. - X : Fact, 1999. - P. 223.

6. Hoya T. Methods of market economy in American and Russian environmental law // Bulletin of the International University. - The Law Series. - Issue 5. - M., 2001. - P. 152. 
7. General theory of state and law. Academic course in 2 volumes. Volume 1. Theory of the State / Ed. MN Marchenko. - M.: "Mirror", 1998. - P. 203-204.

8. Kolbasov O.S. Ecology: politics - law. - M : Science, 1976.

9. Kostytsky V.V. Distribution of power in legal state and social and normative fixing of the idea of freedom and democracy. - Sociology of law. - 2011, № 2, - P. 3-10.

10. Kostytsky V. Ecological function of the state and economic and legal mechanism of environmental protection // Law of Ukraine. - 2004. № 1. - P. 147.

11. Kostytsky V.V. Ecological law as a theological and sociological phenomenon / V. Kostytsky // Ecological law. - 2013. - № 1. - P. 4-12.

12. Kostysky V.V. Ecology of Transition: Law, State, Economy (Economic and Legal Mechanism of Environmental Protection in Ukraine) / V.V. Kostysky; Institute for Legislative Predictions and Legal Expertise. - (Series "Ecological Library"; № 5) (Library of the magazine "Small and Medium Business/-K.: USSB SME Eusmeu, 2003. - 772 p.

13. Kostytsky V.V. Environmental Law of Ukraine: [textbook] 1 book. / Vasyl Kostytsky, - Drohobych: Circle, 2012. - 360 p.

14. Kostytsky V.V. Local stlfgovernment and sustainable use of nature. - K., 1989.

15. Kostytsky V.V. Political Parties in the System "Civil Society and State" // Law of Ukraine.- 1995. - № 12.

16. Kostytsky V.V. Power of the people: seven functional branches of power (Renaissance problems in the theory of law). - Small and Medium Business, 2010. - P. 4-14.

17. Kostytsky Vasyl. State-building processes are components of multiparty development in Ukraine (political and legal analysis). - K., 2002. $-60 \mathrm{p}$.

18. Kostytsky V.V. etc. The interaction of society and nature: sociophilosophical problems. (Lecture notes). - Lviv, 1992. - $32 \mathrm{p}$.

19. Muhamet - Irekle A. On the Function of the Rule of Law in Modern Nature Management. Monograph. - M.: "NIA-Nature", 2002. $272 \mathrm{p}$.

20.Petrov V.V. The concept of interaction between society and nature - the scientific basis of environmental law / Methodological problems of law / Ed. M.N. Marchenko. - M.: Moscow State University Publishing House, 1994. - P. 138. 
21. Political Foundations of Modern State Strategy / Political Studies. Issue 2. - K : Ukrainian Perspective Foundation, 1995 - P. 4.

22. Politology. Textbook / Edited by prof. Kremena V.G., prof. Gorpacha MI - Kharkiv: Unicorn Printing Center, 2001. - 640 p.

23. Problems of the general theory of law and state. Textbook for universities / Under commonly. ed. V.S. Nersesyan. - M.: "Norma", 2001.

24. Shemshuchenko Y.S. Organizational and Legal Issues of Environmental Protection in the USSR. - K.: Sciences. opinion. - 1976 $276 \mathrm{p}$.

25. Sokolov A. Kant and Contemporaneity (concept of legal state in the mirror of comparative law) // Political Reading. - 1995. - № 1. - P. 4.

26. Timoshenko V.I. Legal power: theoretical-historical researches. K.: Naukova Dumka, 1994. - P. 16. Tomenko M. The Ukrainian Perspective: Historical and 27.

27. Spiridonov L.I. State and Law Theory. - M., 1996.

28. Schmidhaney S. Changing course. Prospects for development and environmental problems: an entrepreneur approach. - M., 1994.

29. The history of political and legal doctrines of the XVIIXVIII centuries. / Editorial.: Gratsiansky P.S. and others - M.: Science, 1989. - S. 116-129.

30. The history of political and legal doctrines of the XVIIXVIII centuries. / Editorial.: Gratsiansky P.S. and others - M.: Science, 1989. - P. 198.

31. Valevsky O.L. State policy in Ukraine: methodology of analysis, strategy, mechanisms of implementation. - K : NISD, 2001. P. 121-126.

\section{Information about the author:} Kostytsky V., Doctor of Law (DrSc.), Professor, President of the International Environmental Academy ORCID: 0000-0003-1692-9810 


\section{CONTENT OF HUMAN RIGHT TO FAVORABLE ENVIRONMENT IN GENERAL INTERNATIONAL LAW}

\section{Getman A. P., Shchokin Y. V., Hetman Y. A.}

\section{INTRODUCTION}

The concept of international human environmental rights has been maturating gradually, as international cooperation practices of states in the field of conservation and rational use of natural resources accumulated and, in fact, as the theory and practice of international human rights protection advanced. The natural result of a gradual development of international legal commitments of states in the environmental sphere was formation of the right to a favorable environment as one of the fundamental international human environmental rights ${ }^{1}$.

The modern doctrine of international law indicates that a general international consensus has been achieved only in regard to four kinds of environmental rights to: a) favorable environment; b) access to environmental information; c) public participation in environmental decisionmaking; and d) access to environmental justice ${ }^{2}$. These rights are regarded as a generally recognized international legal framework for a subsequent broad-scale development of the entirety of international human environmental rights. Thus, apart from the above-mentioned rights, the following rights are also identified: to health; to access to fresh water; property right to natural resources, etc ${ }^{3}$.

The right to a favorable environment is a fundamental subjective human right. As A. M. Solntsev notes, its place in the system of human

${ }^{1}$ This, in particular, is emphasized by T.R. Korotkiy. He points out that the first traditional domains of regulating international environmental rights were relations pertaining to environmental protection, as well as those pertaining to rational nature management. And only later on, the scientist continues, the said domains were supplemented by environmental safety relations and those securing human environmental rights. (T.R. Korotkiy, Ecologization of international law in the light of environmental human rights, p. 134, at: http://archive.nbuv.gov.ua/portal/Soc_Gum /App/2012_44/ Korotkiy.pdf) [in Russian].

${ }^{2}$ Solntsev A.M., Protection of Environmental Human Rights, 2015, p. 25 [in Russian]; N.B. Mushak, Conceptual approaches to classification of human rights under globalization processes, Chasopys Kyivskoho universytetu prava, 2011, No 2, p. 300) [in Ukrainian].

${ }^{3}$ Mushak N.B., supra. 
rights is determined by the fact that providing basic life support it acts as inborn, intrinsic human quality ${ }^{4}$. In other words, this right is so valuable that it tops the hierarchy of the presently shaping international human environmental rights as well as the hierarchy of long-established in international law and national legal systems civil, political, social, economic, and cultural rights i.e. human rights of first and second generations.

This right corresponds to the human right of the Ukrainian national law to an environment that is safe for life and health, directly provided for in Art. 50 of the Constitution of Ukraine. Experts point out that the formulation of the right is so judgmental that its profound meaning leads to paradoxical results. On the one hand, an axiological sense of the norm is so significant that it claims to have the status of "an international legal environmental imperative" . While on the other hand, the latitude of thought about the norm content, the ambiguity of interpretation of every single word recorded therein diminishes the practical value of the norm, turning it into a slogan. It is well-known that in a modern democratic state governed by the rule of law the legal provisions for human rights should not be too much itemized so as courts could have a certain degree of discretion in interpreting a specific human right depending on the specificity of every examined case. At the same time, it is the positive law that should indicate the lines of interpretation and even its limits in a particular context.

The lines and limits of interpreting the human right to an environment that is safe for life and health are determined in two legal domains national-legal and international-legal. They are intermingled, interconnected and affect each other. The Ukrainian legislators who accepted voluntarily the concept of the primacy of international law thereby consented to priority application of international-legal standards of the law under consideration. Yet, these standards are still insufficiently explored in the Ukrainian juridical science.

The objective of the present paper is to determine the content of the human right to a favorable environment and sources of its consolidation in the modern international law.

\footnotetext{
${ }_{5}^{4}$ Solntsev A.M., supra at pp. 25, 26.

${ }^{5}$ Getman A.P. \& Kostytskyi V.V., Human environmental rights in the national and international legal doctrine, Problems of Legality, 2013, Issue 124, p. 78 [in Ukrainian].
} 


\section{Recognition of the idea of protection of international human environmental rights}

At the beginning of the development of international human environmental rights, a number of leading experts expressed their doubts about the viability of separating these rights, pointing out, in particular, a possible blurring and, consequently, decline in legal influence of the acknowledged human rights, well enshrined in general and regional international law and tried by extensive practice of their application. The formulation of international environmental rights, brought up for discussion, was criticized for non-specificity, obscurity, and lack of proper level of specialization ${ }^{6}$.

This, in particular, was mentioned by D. Shelton in 1991. She agreed with the idea that both the areas of international law - human rights and environmental protection - ultimately strive to attain the highest quality of a sustainable human life within the framework of the existing global ecosystem ${ }^{7}$. However she also stressed their fundamental innate contradictions, emergent at the primary level of goal setting. The researcher wrote that the essential interest of the human rights law consists in protection of individuals living in a given society, while the goal of environmental law is sustaining life around the world by correlating today's needs and possibilities with the future needs and possibilities ${ }^{8}$.

D. Shelton indicated a close connection between environmental rights and the political consensus reached in intergovernmental relations which affects directly the efficiency of the work on compliance with international procedures $^{9}$. As an example of the negative consequences of inefficient implementation of international human rights-based instruments due to a lack of political consensus among the leading states in the international arena, the researcher instances the fate of the 1966 International Covenant on Economic, Social and Cultural Rights. The USA refused to recognize and apply it, having declared the very idea of those human rights to be "a myth" ". Similarly, she pointed out the solidarity nature of environmental

${ }^{6}$ Lewis B., Environment Rights or A Right to the Environment? Exploring the Nexus between Human Rights and Environment Protection, Macquarie Journal of International and Comparative Environment Law, 2012, Vol. 8 (1), pp. 44-45.

Shelton D., Human Rights, Environmental Rights and the Right to Environment, Stanford Journal of International Law, 1991, Vol. 28, p. 111.

${ }^{8} \mathrm{Id}$.

${ }^{9}$ Id., at pp. 117, 118.

${ }^{10}$ Id., at p. 121. 
rights which rarely refer to a single individual. Due to a dynamic and changeable character of the nature, its deterioration, the environmental rights, as a rule, are applied most widely ${ }^{11}$.

Another well-known environmentalist lawyer A. Boyle confessed that in 1996 he shared the skepticism expressed by numerous Western experts with regard to an idea of enshrining in law the human right to a favorable environment. He writes that it looked like an attempt to turn an essentially political issue into a legal one, which could help seize power from democratically accountable politicians and transfer it to courts or treaty bodies. The Western governments were sure that this UN idea was stillborn $^{12}$. As years went by, the scientist stresses, he did not lose his skepticism, yet he had to correct his stand substantially, mostly because he realized the significance of that right for the countries where environmental concerns are more critical and complicated than in Western Europe ${ }^{13}$.

L. Horn agrees that the human right to a healthy environment is underpinned by the need for survival. At the same time, however, she focuses on the reasoning typical of the representatives of multiple international non-governmental environmental organizations and movements which follow a tradition of opposing the "objective" needs of a modern urbanized society to the "objective" needs of the fauna in particular, and the wildlife in general. She argues that this approach is justified, since preservation of the environment is necessary for improving the quality of human life. The problem aspect of the approach lies in emphasizing the supremacy of human beings over the nature. It supports a utilitarian theory and an assumption that the nature serves largely the purpose of humans' well-being ${ }^{14}$.

Despite numerous objections, the need for finding a commonly acceptable solution to the problem of substantiating international human environmental rights and providing each of them with their own unique content was obvious. At the highest international level this was best expressed by Vice-President of the International Court of Justice

${ }^{11}$ Id., at p. 124.

12 Boyle A., Human Rights and the Environment: Where Next? European Journal of International Law, 2012, Vol. 23, P. 627.

${ }^{13}$ Boyle A., supra at p. 627.

${ }^{14}$ Horn L., The Implications of the Concept of Common Concern of a Human Kind on a Human Right to a Healthy Environment, Macquarie Journal of International and Comparative Environment Law, 2004, Vol. 1, p. 239. 
C.G. Weeramantry in his dissenting opinion about the judgment in the case of Gabčíkovo (Hungary/Slovakia, 1997). The Justice declared that environmental protection is a vital part of the modern human rights doctrine, since it is a sine qua non for numerous human rights, such as the right to health, and the right to life itself. It is hardly necessary to prove that damage caused to the natural environment may diminish and undermine all the human rights specified in the Universal Declaration of Human Rights and other human rights instruments ${ }^{15}$.

Later on quite a number of scientists spoke in support of separation of international human environmental rights. At present, systematization of the relevant argumentation is underway. For instance, F.K. Nkusi puts forward the following arguments: a) a connection between human rights and impact of the environment on the life, health, privacy, and property of physical persons is closer than links with other states and the external environment as a whole; b) separation of human rights can give an impetus to provision of higher standards of environment quality based on the states' commitments to take steps aimed at controlling pollutions harmful to people's health and private life; c) the existence of international human environmental rights helps promote the rule of law in the sphere of ecology, since governments become directly responsible for their own faults in implementation of these rights, and for control over pollution, caused by corporations as well; d) respect for human rights encourages public participation in making decisions on environmental issues, facilitates access to the relevant information and justice; e) human rights allow differentiating more clearly between various components of public interests in the sphere of environmental protection; f) human rights are associated with climate change ${ }^{16}$.

S. Glazebrook puts forward the main arguments made by the opponents of separation of international human environmental rights, entering into a debate with them. In particular, she agrees with their opinion that introduction of new rules may affect negatively the established system of human rights, devaluating them. At the same time, she notes that reluctance to adapt the existing documents or extend the rights in accordance with changing circumstances may produce the same

\footnotetext{
${ }^{15}$ Gabčíkovo-Nagymaros Project (Hungary/Slovakia), Judgment of 25 September 1997, Separate Opinion of Vice-President Weeramantry, I.C.J. Reports, 1997, pp. 91-92.

${ }^{16}$ Nkusi F.K., A Right to Healthy Environment: The Nexus between Environmental Protection and Human Rights, East African Journal of Science and Technology, 2015, Vol. 5, Issue 1, p. 222.
} 
effect. The scientist believes that new rights should not be added if they are trivial, but the right to a quality environment can be regarded as one of the keystones determining other rights ${ }^{17}$. Recognizing the difficulty of coordination of the new right content with that of the existing rights, she points out that even if the new right were not articulated yet, this does not mean it is nonexistent ${ }^{18}$. She emphasizes that any environmental right will include in itself the right to biodiversity and responsibility for protection of biodiversity and ecosystems ${ }^{19}$. According to S. Glazebrook, individualization of the right to the environment does not contradict its collective nature. Individual and collective interests always coincide in the right protection, individualization merely enhancing $\mathrm{it}^{20}$.

B. Weston and D. Bollier indicate that, firstly, human rights provide the level of responsibility that goes beyond the scope of other legal obligations; they represent physical values of "the highest" legal and moral order, and therefore, infringement thereof entails stronger moral condemnation than other violations ${ }^{21}$. Secondly, according to the scientists, this is exactly what promotes the influence on the authorities, which is of great importance, especially when persons affected as a result of large-scale environmental catastrophes try to hold liable big economic and political forces. Thirdly, human rights protection opens up direct access to international human rights machinery. In the fourth place, human rights having greater moral strength than usual legal obligations lay the legal basis for the respective political and public activity ${ }^{22}$. And in the fifth place, as B. Weston and D. Bollier state, human rights stimulate formation of initiatives inside and outside the civil society, meant to contribute to meeting primary human needs ${ }^{23}$.

In the view of some scientists, individualization of environmental rights does not result in strengthening of the utilitarian theory, set against 'green' or 'deep ecology' philosophic mindset, widespread among international environmental human rights organizations and movements.

17 Glazebrook S., Human Rights and the Environment. Victoria University of Wellington Law Review, 2009, Vol. 40, p. 317.

${ }^{18}$ Glazebrook S., supra at p. 317.

${ }^{19}$ Id., at p. 318.

${ }^{20}$ Id., at pp. $319-320$.

${ }^{21}$ Weston B.H. \& Bollier D., Regenerating the Human Right to a Clean and Healthy Environment in the Commons Renaissance. Essay, Version 1.0., September 2011, P. 74, at: http://commonslawproject.org/sites/default/files/Regenerating\%20Essay\%2C\%20Part\%20I.pdf.

${ }^{22}$ Id., at p. 75.

${ }^{23}$ Id., at p. 76. 
The theorists of deep ecology highlight crucial distinctions between individual environmental rights and objective needs of non-human life. They stress that environmental rights, like all human rights, cannot be anthropocentric, since human needs do not match the needs of the wildlife, more often contradicting them. The legal quintessence of this philosophy became the theory of Mother Nature's rights, embodied in the Universal Declaration of the Rights of Mother Earth, adopted at the Conference on Global Warming and Rights of Mother Earth, held in Cochabamba (Bolivia) on 22 April 2010, which united in a unique way state agents and civil society representatives from over 100 nations. The Declaration is apparently of non-anthropocentric nature. This is clearly indicated, in particular, in para. 5 Art. 1 declaring the right of Mother Earth and all life forms to all the inherent rights regardless of usefulness for human beings $^{24}$.

However modern advocates of environmental rights individualization not only look differently upon deep ecology philosophers' concerns; moreover, they believe that it is individualization that will reduce these controversies. This, for example, is mentioned by B. Lewis. She emphasizes an idea that inclusion of the right to a healthy environment into international human rights treaties will not only make it equal to other human rights, but will also help balance the general environmental needs with people's own needs ${ }^{25}$. The same position was taken up by the above-mentioned B. Weston and D. Bollier. However, they made a distinction between traditional anthropocentrism and that of the intergenerational rights approach. The latter is practically non-egoistic and much less human-oriented than the anthropocentrism of the traditional human rights approach that focuses largely on persons unaware of their potential distant future ${ }^{26}$.

In fact, a new concept of the common concerns of mankind that replaced the mankind common heritage concept was meant to overcome this discrepancy and blur out the said contradictions. The former concept, as distinct from the latter, according to L. Horn, is more advantageous for characterizing the climate and biological diversity as common concerns components. But the key legal difference between the 'common concerns' and 'common heritage' consists in that the common concerns penetrate the

${ }^{24}$ Universal Declaration of the Rights of Mother Earth, 28 April 2010 (Cochabamba, Bolivia), at: http://www.rightsofmotherearth.com/универсальная-декларация-прав-материземли [in Russian].

${ }^{25}$ Lewis B., supra at p. 41.

${ }^{26}$ Weston B.H. \& D. Bollier, supra at p. 42. 
domain of the states' exercising sovereign powers, and link them with global interests ${ }^{27}$. In other words, common heritage of mankind law is limited mainly to international territories ${ }^{28}$, while the emerging law of common concerns of mankind is international in the sense that it does not recognize any state borders.

\section{Stages of forming the content of legal standards of the human right to a favorable environment in general international law}

The human right to a favorable environment was being formed as international environmental law itself was evolving. The doctrinal periodization of the latter, as a rule, is related to a number of universal international conferences, which marked the adoption of international legal and political documents that accumulated sometimes challenging consensus on pressing aspects of environmental protection.

The first stage - 1839-1972. Its start dates back to 2 August 1839 - the date of signing a bilateral Convention on dredging oysters and fishing near the shores of Great Britain and France ${ }^{29}$. The end of it was completion of the preparatory work for 1972 UN Conference on the Human Environment held in Stockholm.

The second period is "the Stockholm era". The timeframe of the period includes the results of the work of the UN Stockholm Conference on the Human Environment held in 1972 and preparation for the United Nations Conference on Environment and Development (UNCED), Rio de Janeiro, 1992. During that period, the basic normative framework for this area of law was formed - more than 1,100 international instruments were adopted that were either completely devoted to environmental issues or contained important provisions relating to the environment ${ }^{30}$.

The third period - "the Rio de Janeiro era", which lasted from 1992 to 2012, that is from the time of adoption of the Declaration on Environment and Development at the UN Conference on Environment and Development of June 3-14 1992, and to the next conference held in Rio de Janeiro (Rio+20).

${ }^{27}$ Horn L., supra at p. 244.

28 Malanczuk P., Akehurst's Modern Introduction to International Law, 1997, p. 207-208; M. N. Shaw, International Law, 2008, pp. 533-534.

${ }^{29}$ M.N. Kopylov, S.M. Kopylov \& V.A. Mishlanov, International Environmental Law is 175, Moscow Journal of International Law, 2014, № 1 (93), p. 104 [in Russian].

${ }^{30}$ Weiss E.B., The Evolution of International Environmental Law, Japanese Yearbook of International Law, 2011, p. 6. 
The fourth period - a modern one - is connected with a new wave of international law "ecologization" and actualization of fighting for preservation of climate and biological diversity ${ }^{31}$.

\subsection{The stage of primary "ecologization" of generally recognized human rights and freedoms (1839-1972)}

As E. B. Weiss puts it, the period before 1972 was the time of "early glimmers" in the development of international environmental law. Its principles and standards were poorly developed, and, on the one hand, convictions that states had complete sovereignty over their territories and natural resources were dominating; on the other hand, almost religious "respect for the nature" was universal ${ }^{32}$.

In that context, the "glimmers" of the human right to a favorable environment was hardly perceivable. In actual fact, it is only by the end of the period - after World War II and foundation of the UNO - that inalienable civil, socio-economic, and cultural human rights were enshrined in the universal and regional international law, following decades of work aimed at general legal protection of human environmental needs. This refers to the right to life (Art. 3 of the 1948 Universal Declaration of Human Rights, Art. 6 of the 1966 International Covenant on Civil and Political Rights); the right to the living standards, including food, housing, healthcare, and social services, which are necessary to support the health and welfare (para. 1 Art. 25 Universal Declaration of Human Rights (1948), Art. 11 of the International Covenant on Economic, Social, and Cultural Rights (1966)); the right to the highest level of physical and mental health (Art. 12 of the International Covenant on Economic, Social, and Cultural Rights (1966)).

We would like to stress that during that period the forming practice of interpreting the legal standards was but most general and very close to their common meaning and original spirit. It was quite far from the environmental agenda. Even within the scope of applying such an advanced regional human rights instrument as the Convention for the Protection of Human Rights and Fundamental Freedoms of 1950, the first "environmental" cases appeared long after the period of forming international environmental law was over i.e. after 1972.

\footnotetext{
${ }^{31}$ Kopylov M.N., Kopylov S.M. \& Mishlanov V.A., supra at pp. 113-114.

${ }^{32}$ Weiss E.B., supra at pp. 2-4.
} 
Thus, the first claims submitted for consideration to the Commission on Human Rights in the 1960s-1970s, addressing various environmental aspects (Dr. S. v. the Federal Republic of Germany, Application No. 715/60, Decision of inadmissibility of 5 August 1969; X. and Y. v. the Federal Republic of Germany, Application No.7407/76, Decision of inadmissibility of 13 May 1976), were dismissed as ratione materiae with the Convention. The first environmental cases on which the Commission agreed to pass judgment despit ratione materiae date from the 1980s (Arrondelle v. the United Kingdom, Application No. 7889/77, Decision of 15 July 1980; G. and Y. v. Norway, Application No. 9415/81, Decision of 3 October 1983, and other cases). In the same period the first 'environmentally-related' decisions of the European Court of Human Rights (ECHR) appear (Sporrong and Lönnroth v. Sweden, Judgment of 23 September 1982; Gillow v. the United Kingdom, Judgment of 23 October 1986$)^{33}$.

It should be mentioned, though, that each of the above-said decisions of the Commission and the Court was merely the result of their own longlasting procedures, preceded by inner-state trial procedures on the relevant cases. For applicants, a connection between environmental protection problems and conventional rights was apparent initially. Yet, even now, ECHR, when making judgment ratione materiae and touching, to a degree, upon environmental problems, underlines that the Convention standards are not intended for that. Its standpoint stated in para. 52 of the court decision on the case of Kyrtatos v. Greece, (2003) is well-known: neither Article 8, nor any other article of the Convention was purposefully meant to provide a general environmental protection as such ${ }^{34}$.

However the bulk of the ECHR practice, more or less related to protection of the human right to a favorable environment, formed according to 'non-environmental' articles, has reached a critical level which makes it possible to gain a clear impression of what the content of this right should be. At the same time, from the ideological perspective, the practice of ECHR is remarkable because it has demonstrated conclusively both the closest connection between conventional and environmental human rights and the necessity for environmental rights individualization.

${ }^{33}$ García D.I. San José, Environment Protection and the European Convention on Human Rights, Council of Europe Publishing, 2005, pp. 7-11; S. Kravchenko \& J.E. Bonine, Interpretation of Human Rights for the Environment in the European Court of Human Rights, Global Business \& Development Law Journal, 2012, Vol. 25, p. 245-287.

${ }^{34}$ Case of Kyrtatos v. Greece (Application No. 41666/98), Judgment, 22 May 2003. 


\subsection{The stage of forming a common UN political and expert position on the expediency of individualizing the human right to a favorable environment (1972-1992)}

In the period of 1972-1992, the human right to a favorable environment was individualized in a number of international political documents. It is considered that it was first declared to be an individual human right in the Declaration of the UN Conference on the Human Environment, adopted on June 161972 in Stockholm (Stockholm Declaration, 1972). Pursuant to Principle 1 of the Declaration, "Man has the fundamental right to freedom, equality and adequate conditions of life, in an environment of a quality that permits a life of dignity and wellbeing, and he bears a solemn responsibility to protect and improve the environment for present and future generations".

It should be noted that it is the only principle in the document which its drafters put on record as an individual human right and formulated as a self-executing norm i.e. as a rule of law that can be applied directly by the interested entities. Another human-friendly norm is recorded in Principle 4, but it has the form of an individual obligation, rather than a right: "Man has a special responsibility to safeguard and wisely manage the heritage of wildlife and its habitat, which are now gravely imperiled by a combination of adverse factors." That is why in planning of economic development a prominent place should be given to preservation of nature, including wildlife.

On 28 October 1982, the General Assembly adopted Resolution $37 / 7$ titled the World Charter for Nature. The document links directly human life with a favorable environment. Thus, the preamble to the Charter states that mankind ensures "the supply of energy and nutrients"; "living in harmony with nature gives man the best opportunities for the development of his creativity, and for rest and recreation". Paragraph 9 of the Charter indicates the need for a rational and planned use of nature: "The allocation of areas of the earth to various uses shall be planned, and due account shall be taken of the physical constraints, the biological productivity and diversity and the natural beauty of the areas concerned." Paragraph 10 lays out the rules, according to which natural resources should be "used with a restraint", namely: "a) living resources shall not be utilized in excess of their natural capacity for regeneration; b) the productivity of soils shall be maintained or enhanced through measures which safeguard their long-term fertility and the process of organic decomposition, and prevent erosion and all other forms of degradation; 
c) resources, including water, which are not consumed as they are used shall be reused or recycled; d) non-renewable resources which are consumed as they are used shall be exploited with restraint, taking into account their abundance, the rational possibilities of converting them for consumption, and the compatibility of their exploitation with the functioning of natural systems".

A special attention should be paid to paragraph 23 of the World Charter for Nature. It is the only paragraph that directly applies to man: "All persons, in accordance with their national legislation, shall have the opportunity to participate, individually or with others, in the formulation of decisions of direct concern to their environment, and shall have access to means of redress when their environment has suffered damage or degradation".

In 1983, the General Assembly of the UNO established the World Commission on Environment and Development (WCED), chaired by a famous Norwegian political figure and diplomat Mrs. Gro Harlem Brundtland. In 1987, the Commission published a report under the title of "Our Common Future"35 (hereafter - Brundtland Report), the report that introduced the idea of sustainable development which laid an ideological foundation for the modern UN activity. Thus, para. 4 subsection 1 Chapter 2 of Brundtland Report holds: "The satisfaction of human needs and aspirations in the major objective of development. The essential needs of vast numbers of people in developing countries for food, clothing, shelter, jobs - are not being met, and beyond their basic needs these people have legitimate aspirations for an improved quality of life. A world in which poverty and inequity are endemic will always be prone to ecological and other crises. Sustainable development requires meeting the basic needs of all and extending to all the opportunity to satisfy their aspirations for a better life" ${ }^{, 36}$.

On the whole, Brundtland Report appeals to states. Nevertheless, a number of its provisions determined the prospects for developing individual human rights. They are of a clearly pronounced environmental nature. For example, para. 80 Chapter 12, concerning the means for legal regulation of sustainable development, stipulates that "human laws must

${ }^{35}$ Report to the UN General Assembly of the World Commission on Environment and Development "Our Common Future" of 4 August 1987 (Doc. A/42/427, Russian), 411 p., at: http://www.un.org/ru/ga/pdf/brundtland.pdf [in Russian].

${ }^{36} \mathrm{Id}$. 
be reformulated to keep human activities in harmony with the unchanging and universal laws of nature" ${ }^{, 37}$. Paragraph 82 of the same chapter states that "recognition by states of their responsibility to ensure an adequate environment for present as well as future generations is an important step towards sustainable development. However, progress will also be facilitated by recognition of, for example, the right of individuals to know and have access to current information on the state of the environment and natural resources, the right to be consulted and to participate in decision making on activities likely to have a significant effect on the environment, and the right to legal remedies and redress for those whose health or environment has been or may be seriously affected" 38 . It stands to reason that the 'rights of individuals' refer to the rights of every particular person, not the rights of the few.

Paragraph 1 of the Summary of the Proposed Legal Principles for Environmental Protection and Sustainable Development Adopted by the WCED Experts Group on Environmental Law (Annex 1 to Brundtland Report) defines the fundamental human right as follows: "All human beings have the fundamental right to an environment adequate for their health and well being" 39 .

\subsection{The stage of forming common political obligations to ensure the human right to a favorable environment under the UN aegis (1992-2012)}

The first universal political document that embodied the ideas of Brundtland Report was the Declaration on Environment and Development adopted by the UN Conference on Environment and Development held from 3 to 14 June 1992 in Rio de Janeiro. The Rio Conference of 1992 elaborated the principles of international environmental law development, determined its goals and main ways for the states to cooperate in that field. The Conference adopted the Rio Declaration on Environment and Development, United Nations Framework Convention on Climate Change, Convention on Biological Diversity, and Agenda 21.

Discussing establishment of connections, E.B. Weiss points out entwinement of the forming rules of international environmental law with other international law areas, namely: international economic law, law of

\footnotetext{
${ }^{37}$ Id.

${ }^{38}$ Id.

${ }^{39}$ Id.
} 
international security, law of international organizations, and, of course, international human rights law. It should be emphasized that, in the view of the researcher, connection between international environmental law and international protection of human rights manifested itself, in the first place, in individualization of the human right to a clean, favorable and healthy environment ${ }^{40}$.

Without doubt, the position of E.B. Weiss should be fully supported. But at the same time, it stands to mention that the documents adopted at the Rio Conference in 1992 basically apply to states. For example, the principles laid out in the Rio Declaration on Environment and Development address member states and are a sort of agenda for consolidation of their mutual efforts in the environmental sphere. Human rights in this agenda are formulated by Principle 1, although in collective rather than individual capacity. They can be regarded as a priority goal of the Declaration and not as a specific self-executable obligation: "Human beings are at the centre of concerns for sustainable development. They are entitled to a healthy and productive life in harmony with nature".

Many experts have noticed the equivocation of the legal rule formulated in Principle 1. For instance, M.L. Schwartz, making comments on this situation, pays attention to the fact that the Rio Declaration does not explicitly specify 'the right' of an individual to life in a healthy environment as it was done twenty years before by the Stockholm Declaration. The Rio Declaration states that individuals 'are entitled' to a health life. However, the researcher notes, it is not clear if the second term has a narrower meaning than the first one ${ }^{41}$. As S.P. Marks puts it, the wording of Principle 1 does not indicate expressly that there exists a human right to a clean and ecologically balanced environment, but it nails down the problem in human rights parlance ${ }^{42}$. L. Horn is more categorical saying that Principle 1 does not denote directly 'human entitlements' as 'a human right', which can definitely be regarded as a failure of the Rio Declaration and regress in this right evolution ${ }^{43}$.

Neither the UN Framework Convention on Climate Change nor the Convention on Biological Diversity of 1992 addresses human rights. The

\footnotetext{
${ }^{40}$ Weiss E.B., supra at p. 15.

${ }^{41}$ Schwartz M.L., International Legal Protection for Victims of Environmental Abuse. Yale Journal of International Law, 1993, Vol. 18, Issue 1, Art. 15, p. 374.

${ }^{42}$ Marks S.P., Emerging Human Rights: A New Generation for the 1980s? Rutgers Law Review, 1981, Vol. 33, p. 443.

${ }^{43}$ Horn L., supra at p. 235.
} 
Agenda 21 is a full-fledged agenda for actions which the 1992 Rio Conference participant states deem necessary to take for effective environmental protection. It is a set of political commitments of the states rather than legal ones, as is mentioned in para. 1.3 of the document: "Agenda 21 addresses the pressing problems of today and also aims at preparing the world for the challenges of the next century. It reflects a global consensus and political commitment at the highest level on development and environment cooperation" "44. The Agenda 21 does not touch upon environmental human rights issues either, which by no means indicates a lack of interest in it.

On 31 August 1989, the United Nations Sub-Commission on the Prevention of Discrimination and Protection of Minorities in its Decision 1989/108 suggested that Mrs F.Z. Ksentini prepare a brief note on methods for researching environmental problems and their interrelation with human rights. None of the UN bodies has ever dealt with these issues. After a series of discussions of the work done by F.Z. Ksentini as Special Rapporteur on the subject, her powers were enhanced considerably. On 6 July 1994, she submitted to the UN Economic and Social Council, the Commission on Human Rights and the SubCommission on the Prevention of Discrimination and Protection of Minorities her Final Report titled "Human Rights and the Environment", known as "Ksentini Report"

The Report presents environmental aspects of realization of such fundamental human rights and freedoms as the right to life (para. 172-175); the right to health (para. 176-187); the right to food (para. 188-191); the right to occupational health (para. 192-194); the right to housing (para. 195-202); the right to information (para. 203-216); freedom of association (para. 224-225); cultural rights (para. 226-234). The Special Rapporteur pointed out an indispensible link between effective environmental protection and effective realization of these rights. In particular, para. 252 of the Report holds that "effective implementation of

${ }^{44}$ Report of the United Nations Conference on Environment and Development. Rio de Janeiro, 3-14 June 1992 V. I: Resolutions adopted at the Conference (A/CONF.151/26/Rev.1(Vol.1)), UN, New-York, 1993, p. 11 [in Russian].

${ }^{45}$ Human Rights and the Environment. Final Report prepared by Special Rapporteur Mrs Fatma Zohra Ksentini (E/CN.4/Sub.2/1994/9, Russian) of 6 July 1994. UN Economic and Social Council. Commission on Human Rights. The Sub-Commission on the Prevention of Discrimination and Protection of Minorities. Session 46. Para. 4 of Preliminary agenda, 121 p. at: https://digitallibrary.un.org/record/226681/files/E_CN.4_ Sub.2_1994_9-RU.pdf?version=1 [in Russian]. 
the right to a satisfactory environment cannot be dissociated from the twinned efforts to preserve the environment and ensure the right to development. Nor can it be achieved without resolute action to ensure the enjoyment of all human rights" 46 . As can be judged by the text of the Report, the content of the human right to a healthy environment consists of the environmental aspects of the said fundamental human rights. Besides, as para. 255 of the Report runs, a specific feature of the right to a healthy environment is its preventive nature: "the right to a satisfactory environment is also a right to prevention which gives a new dimension to the right to information, education and participation in decision-making. The right to restitution, indemnification, compensation and rehabilitation for victims must also be seen from the angle of the special responsibility that would follow from the absence of preventive measures" ${ }^{\text {"47 }}$.

Annex I to Ksentini Report presents "Draft Principles on Human Rights and the Environment" ${ }^{\text {. }}$. The draft Declaration consists of Preamble and 27 paragraphs divided into 5 parts. In effect, this is the first draft instrument on environmental human rights submitted for consideration at such a high official international level. Keeping in mind the structure of the Draft and the order of presentation of normative materials, it is obvious that the right to a secure, healthy, ecologically sound environment formalized in para. 2 Part I, according to Special Rapporteur, is fundamental and hierarchically overarching in the system of individual environmental rights. All other rights are devoted to separate aspects of its realization: the right to freedom from pollution, environmental degradation and activities that adversely affect the environment, threaten life, health, livelihood, well-being or sustainable development within, across or outside national boundaries (para. 5); the right to protection and preservation of the air, soil, water, sea-ice, flora and fauna, and the essential processes and areas necessary to maintain biological diversity and ecosystems (para. 6); the right to the highest attainable standard of health free from environmental harm (para. 7); the right to safe and healthy food and water adequate to their well-being (para. 8); the right to a safe and healthy working environment (para. 9); the right to adequate housing, land tenure and living conditions in a secure, healthy and ecologically sound environment (para. 10) etc ${ }^{49}$.

\footnotetext{
${ }^{46}$ Id., at p. 93.

${ }^{47}$ Id., at p. 94 .

${ }^{48}$ Id., at pp. $98-102$.

${ }^{49}$ Id., at p. 99.
} 
A new stage in enshrining in international law of conceptions of sustainable development and human environmental rights was marked by the Johannesburg Declaration on Sustainable Development, adopted at the World Summit on Sustainable Development in Johannesburg, 26 August 4 September 2002. In the context of the present paper, the Declaration is of particular interest in that it specifies basic human needs which, in the view of its drafters, ensure 'indivisibility of human dignity'. The literal formulation is given in para. 18: "We welcome the focus of the Johannesburg Summit on the indivisibility of human dignity and are resolved, through decisions on targets, timetables and partnerships, to speedily increase access to such basic requirements as clean water, sanitation, adequate shelter, energy, health care, food security and the protection of biodiversity."

To our mind, this provision of the Declaration, although not formulated as a self-executing norm, nevertheless gives a clue to understanding the content of 'a favorable environment' concept. In this case, it demonstrates a universal political consensus which allows disagreeing with the opinions existing in the doctrine on general lack of interpreting the notion of 'favorable' or any standards thereof in the modern international law ${ }^{50}$.

As it follows from para. 18 cited above, an environment is 'favorable' when living in it permits people to preserve their dignity, as their basic needs are satisfied, in particular: the needs for pure water, sanitation, adequate housing, energy, healthcare, food safety and protection of biological diversity.

The hopes of environmentalists, related to the UN Conference on Sustainable Development in Rio de Janeiro (Rio+20), held on 20-22 June 2012 (at the twentieth jubilee of adoption of the Rio de Janeiro Declaration on Environment and Development 1992), alas, have not been fulfilled. For the most part, two topics were discussed: a) creation of 'green economy' to achieve sustainable development and poverty eradication; and b) improvement of international coordination of sustainable development ${ }^{51}$. Neither a research of the Office of the UN High Commissioner for Human Rights on the relationship between

\footnotetext{
${ }^{50}$ A.M. Solntsev, supra at pp. 25-27 [in Russian].

${ }^{51}$ The Outcome Document of the United Nations Conference on Sustainable Development in Rio de Janeiro (20-22 June 2012): Draft Resolution submitted by President of the General Assembly, "The future we want" (A/66/L.56, Russian), 24 July 2012, at: https://documents-dds-ny.un.org/doc/UNDOC/LTD/N12/436/90/PDF/N1243690.pdf? OpenElement [in Russian].
} 
climate change and human rights, conducted before RIO $+20^{52}$, nor persistent open calls of the High Commissioner Navi Pillay herself to the Conference member states to use her for the development of international environmental human rights were taken into consideration ${ }^{53}$.

\subsection{Current activity of the UN Human Rights Council on development of the content of the human right to a favorable environment (2012 till present)}

Immediately after the Conference, the Office of the UN High Commissioner for Human Rights and the UN Human Rights Council boosted their work on development of the international environmental protection agenda. The Council sessions started hearing annual reports made, first by the Independent Expert, and later on - since enhancement of his status in 2016 - by the Special Rapporteur on the issue of human rights obligations relating to the enjoyment of a safe, clean, healthy and sustainable environment John H. Knox ${ }^{54}$. Based on them, from 2012 to

${ }^{52}$ Report of the Office of the United Nations High Commissioner for Human Rights on the Relationship between Climate Change and Human Rights of 15 January 2009 (A/HRC/10/61, Russian), at: https://documents-dds-ny.un.org/doc/UNDOC/GEN/G09/103/ 46/PDF/G0910346.pdf? OpenElement; Analytical study of Relationship between Human Rights and the environment. Report of the United Nations High Commissioner for Human Rights of 16 December 2011 (A/HRC/19/34, Russian), at: http://www.ohchr.org/ Documents/HRBodies/HRCouncil/RegularSession/Session19/A-HRC-19-34_ru.pdf [in Russian].

${ }^{53}$ Open Letter from the United Nations High Commissioner for Human Rights Navi Pillay to Member States of the UN Conference on Sustainable Development in Rio de Janeiro (Brazil, 20-22 June 2012) of 30 March 2012, at: http://www.ohchr.org/Documents/ Issues/Development/OpenLetterHC.pdf; Statement by the United Nations High Commissioner for Human Rights: Navi Pillay calls on the member states to include human rights into Rio+20, 18 April 2012, at: http://www.ohchr.org/RU/NewsEvents /Rio20/Pages/ Newsreleases.aspx; Goal: Human Rights in Rio, 2 May 2012, at: http://www.ohchr.org/ RU/NewsEvents/Stories /Pages/WantedHumanRightsinRio.aspx [in Russian].

${ }^{54}$ Report of the Independent Expert on the issue of human rights obligations relating to the enjoyment of safe, clean, healthy and sustainable environment John H. Knox. Preliminary report of 24 December 2012 (A/HRC/22/43, Russian) / Human Rights Council. Session 22, at: https://documents-dds-ny.un.org/doc/UNDOC/GEN/G12/189/74/PDF/ G1218974.pdf?OpenElement [in Russian]; Report of the Independent Expert on the issue of human rights obligations relating to the enjoyment of safe, clean, healthy and sustainable environment John H. Knox. Analytical report of 30 December 2013 (A/HRC/25/53, Russian) / Human Rights Council. Session 25, at: http://www.ohchr.org/EN/HRBodies/ HRC/RegularSessions/Session25/Documents/A-HRC-25-53_ru.doc [in Russian]; Report of the Independent Expert on the issue of human rights obligations relating to the enjoyment of safe, clean, healthy and sustainable environment, John H. Knox, Compilation of good 
2017 the Council adopted a number of resolutions ensuring the development of international environmental human rights obligations and their fulfillment. For that purpose, two main areas were designated: a) general international legal obligations relating to the enjoyment of a safe, clean, healthy and sustainable environment ${ }^{55}$, and b) obligations, relating to climate change ${ }^{56}$.

practices, 3 February 2015 (A/HRC/28/61) / Human Rights Council. Session 28, at: http://www.ohchr.org/EN/HRBodies/HRC/RegularSessions/Session28/Documents/A_HRC _28_61_EN.doc [in Russian]; Report of the Independent Expert on the issue of human rights obligations relating to the enjoyment of safe, clean, healthy and sustainable environment, John H. Knox, 1 February 2016 (A/HRC/31/52, Russian) / Human Rights Council. Session 31, at: http://www.ohchr.org/EN/HRBodies/HRC/RegularSessions/ Session31/Documents/A\%20HRC\%2031\%2052_R.docx [in Russian]; Report of the Independent Expert on the issue of human rights obligations relating to the enjoyment of safe, clean, healthy and sustainable environment, 28 December 2015 (A/HRC/31/53, Russian) / Human Rights Council. Session 31, at: https://documents-dds-ny.un.org/doc/ UNDOC/GEN/G15/292/98/PDF/G1529298.pdf?OpenElement [in Russian]; Report of the Independent Expert on the issue of human rights obligations relating to the enjoyment of safe, clean, healthy and sustainable environment,19 January 2017 (A/HRC/34/49, Russian) / Human Rights Council. Session 34, at: https://documents-dds-ny.un.org/doc/UNDOC/ GEN/G17/010/01/PDF/G1701001.pdf?OpenElement [in Russian].

${ }^{55}$ Resolution of Human Rights Council 19/10 "Human Rights and the Environment" of 22 March 2012. General Assembly. Official reports. Session 67. Annex No 53 (A/67/53, Russian). Report of Human Rights Council. UN, New York, 2012, pp. 42-45, at: https://documents-dds-ny.un.org/doc/UNDOC/GEN/G12/161/19/PDF/G1216119.pdf?Open

Element [in Russian]; Resolution of Human Rights Council 25/21 "Human Rights and the Environment" of 28 March 2014. General Assembly. Official reports. Session 69. Annex No 53 (A/69/53, Russian). Report of Human Rights Council. UN, New York, 2014, pp. 101-104, at: https://documents-dds-ny.un.org/doc/UNDOC/GEN/G14/142/70/PDF/G1414270.pdf? OpenElement [in Russian]; Resolution of Human Rights Council 28/11 "Human Rights and the Environment" of 26 March 2015. General Assembly. Official reports. Session 70. Annex No 53 (A/70/53, Russian). Report of Human Rights Council. UN, New York, 2015, pp. 75-78, at: https://documents-dds-ny.un.org/doc/UNDOC/GEN/G15/205/32/PDF/ G1520532.pdf?OpenElement [in Russian]; Resolution of Human Rights Council 31/8 "Human Rights and the Environment" of 23 March 2016. General Assembly. Official reports. Session 71. Annex No 53 (A/71/53, Russian). Report of Human Rights Council. UN, New York, 2016, pp. 58-61, at: https://documents-dds-ny.un.org/doc/UNDOC/GEN/ G16/196/01/PDF/G1619601.pdf?OpenElement [in Russian]; Resolution of Human Rights Council 34/20 "Human Rights and the Environment" of 24 March 2017. General Assembly. Official reports. Session 72. Annex No 53 (A/72/53, Russian). Report of Human Rights Council. UN, New York, 2017, pp. 108-112, at: https://documents-dds-ny.un.org/doc/ UNDOC/GEN/G17/246/53/PDF/G1724653.pdf?OpenElement [in Russian].

${ }^{56}$ Resolution of Human Rights Council 26/27 "Human Rights and the Environment" of 27 June 2014. General Assembly. Official reports. Session 69. Annex No 53 (A/69/53, Russi“Human Rights and the Environment” of an). Report of Human Rights Council. UN, 
The Council resolution 34/20 "Human Rights and the Environment" of 24 March 2017 addressed the matter of mainstreaming the third environmental human rights area - preservation and sustainable use of biodiversity for well-being. In particular, the resolution indicates that "degradation and loss of biodiversity often result from and reinforce the existing patterns of discrimination, and that environmental harm can have disastrous, and at times geographically dispersed, consequences for the quality of life of indigenous peoples, local communities, peasants and others who rely directly on the products of forests, rivers, lakes, wetlands and oceans for their food, fuel and medicine, resulting in further inequality and marginalization"

Thus, the Council brought to a close the discussion on the purposefulness of individualization of international environmental human rights, and separated the human right to enjoinment of a safe, clean, and sustainable environment as being the key one. It stands to mention the wording of the norm. For the time being, it may be deemed to be final. It can be affirmed that it expresses a compromise reached at such a high international level after years-long scientific discussions and political coordination regarding the general name of the individual international environmental human rights norm, embodying the essence of the emerging international environmental human rights.

In the doctrine, there have always been problems as to working out a unified generally recognized formulation of this right, which reflects a lack of common understanding of its meaning and, consequently, its interpretation. Thus, B. Lewis noted that the forming right to a healthy

New York, 2014, pp. 243-247, at: https://documents-dds-ny.un.org/doc/UNDOC/ GEN/G14/142/70/PDF/G1414270.pdf? OpenElement [in Russian]; Resolution of Human Rights Council 29/15 "Human Rights and the Environment" of 26 March 2015. General Assembly. Official reports. Session 70. Annex No 53 (A/70/53, Russian). Report of Human Rights Council. UN, New York, 2015, pp. 231-233, at: https://documents-ddsny.un.org/doc/UNDOC/GEN/G15/205/32/PDF/G1520532.pdf?OpenElement [in Russian]; Resolution of Human Rights Council 32/33 "Human Rights and the Environment" of 1 July 2016. General Assembly. Official reports. Session 71. Annex No 53 (A/71/53, Russian). Report of Human Rights Council. UN, New York, 2016, pp. 334-339, at: https://documentsdds-ny.un.org/doc/UNDOC/GEN/G16/196/01/PDF/G1619601.pdf?OpenElement

[in Russian].

${ }^{57}$ Resolution of Human Rights Council 34/20 "Human Rights and the Environment" of 24 March 2017. General Assembly. Official reports. Session 72. Annex No 53 (A/72/53, Russian). Report of Human Rights Council. UN, New York, 2017, pp. 109, at: https://documents-ddsny.un.org/doc/UNDOC/GEN/G17/246/53/PDF/G1724653.pdf?OpenElement [in Russian]. 
environment has quite a broad range of equivalents: the 'right to a good environment', 'right to a clean, pure environment', 'right to a decent environment' etc. She wrote that, however, each formulation is open to interpretation, retaining the scope and content of the right in question unclear $^{58}$.

The same was mentioned by F.K. Nkusi who analyzed a number of international documents making use of the notions 'a satisfactory environment', 'a healthy and flourishing environment', 'a secure, healthy and ecologically sound environment', 'an environment of a quality that permits a life of dignity and well-being', etc. The scientist stated that insignificant international consensus as regards correct terminology affects negatively the formation of new rules in the sphere ${ }^{59}$.

L. Horn stressed that the lack of a correct definition of the human right to a healthy environment is one of the major obstacles on the way to the right development ${ }^{60}$. Additionally, she observed that the very term of 'environment' needs clarification - it can refer to the entire planet Earth or to man's immediate vicinities ${ }^{61}$.

The remarkable thing is that Special Rapporteur J. H. Knox in his first report to the Council also pointed out to a bulk of different formulations of this right that occur both in the universal international political documents and in regional international agreements, mostly adopted within the frameworks of the leading international regional organizations (the African Union, the League of Arab States, the Association of Southeast Asian Nations (ASEAN), the Council of Europe). He himself combined them within the formulation of the right to a healthy environment as the most recurrent in the documents ${ }^{62}$. In his further reports, the scientist preferred to use the notion of 'the right to enjoyment of a safe, clean, and sustainable environment'.

Apparently, the proposed formulation not only combined the right characteristics, most commonly used in the doctrine and practice, but also arranged in a certain value-based order the basic requirements to the

\footnotetext{
${ }^{58}$ Lewis B., supra at p. 40.

${ }^{59}$ Nkusi F.K., supra at p. 221.

${ }^{60}$ Horn L., supra at p. 239.

${ }^{61}$ Id., at p. 239.

${ }^{62}$ Report of the Independent Expert on the issue of human rights obligations relating to the enjoyment of safe, clean, healthy and sustainable environment John H. Knox. Preliminary report of 24 December 2012 (A/HRC/22/43, Russian). Human Rights Council. Session 22, pp. 6-8, at: https://documents-dds-ny.un.org/doc/UNDOC/GEN/G12/189/74/ PDF/G1218974.pdf?OpenElement [in Russian].
} 
quality of the environment. Firstly, it should be safe for man i.e. not to pose a threat to human existence in principle. Secondly, the criterion of 'cleanliness' definitely supplements the previous one, although it does not reduce 'safety' to a minimum standard, but rather lays increasingly tougher environmental claims to any kind of industrial enterprises or organizations. Thirdly, the criterion of a 'healthy' environment, being most popular in the modern constitutions and international documents, establishes a direct link with the human right to life, the theory and practice of which made it possible to formulate individual the most important attributes typical only of a human being as a living, self-existing organism, a unity of physical and spiritual, natural and social, inherited and acquired throughout life ${ }^{63}$. Health, pursuant to the preamble to Constitution of the World Health Organization is "a state of complete physical, mental and social well-being and not merely the absence of disease or infirmity" ${ }^{\prime 64}$. Therefore, a healthy environment is the external conditions of human life which ensure the state of complete physical, mental and social well-being.

Fourthly, the criterion of a 'sustainable environment indicates largescale and long-term prospects for this right evolution. It will be formed within the sustainable development concept - the main concept of the modern UN activity agenda. This means a commitment to toughening of social justice requirements in the matters of social organization and exploitation of natural resources, aiming to provide the capacity of the biosphere to cope with the effects of human activity ${ }^{65}$. In practical terms, this means a substantial provision of public international interests in realization of the individual right to enjoyment of a safe, clean, healthy and sustainable environment when meeting the relevant interests and needs of a given individual. What we mean is seeking the necessary balance between public and private interests by a number of international interstate human rights bodies in their handling claims of individuals and legal entities. The most illustrative example is the relevant practice of the European Court of Human Rights ${ }^{66}$.

${ }^{63}$ Miroshnychenko O.A., Human Right to Life (theory and practice of international cooperation). Extended abstract of candidate's thesis, 2005, p. 12 [in Ukrainian].

${ }^{64}$ Constitution of the World Health Organization, at: http://apps.who.int/gb/bd/PDF/ bd48/basic-documents-48th-edition-ru.pdf?ua=1\#page=9 [in Russian].

${ }^{65}$ Report to the UN General Assembly of the World Commission on Environment and Development "Our Common Future" of 4 August 1987 (Doc. A/42/427, Russian), p. 24, at: http://www.un.org/ru/ga/pdf/brundtland.pdf [in Russian].

${ }^{66}$ Kravchenko S. \& Bonine J. E., supra at pp. 245-287. 


\section{Objectification of the norm of the human right to a favorable environment in general international law}

The most active efforts of the UN Human Rights Council on international political and doctrinal consensus-building concerning the content of the norm of the human right to a favorable environment facilitate resolving the issue of its practical application, specifically - its formalization. In the world doctrine of international law, there is a prevailing opinion on impossibility of establishing the said norm in a universal international treaty even in the distant future.

It is evident that the present sources - for the most part international political documents - neither match the universal social value of the norm nor provide a solid ground for productive legal work on it. It is the level of "soft law' ${ }^{67}$. It is imperative to enhance the legal significance - "hardness" of a source. The leading experts in the field assert, to our mind not without reason, that such a "hard" source can be international legal custom. Its meaning as an effective regulator of international environmental relations is rarely denied. Particularly, in the Ukrainian science this line is taken by one of the leading experts in international environmental law M.O. Medvedieva. She writes that international custom is getting less and less suitable for regulating of environmental protection activity which, considering deterioration of environmental living standards, requires a clearer, more detailed and unambiguous legal regulation that can be provided only by treaty-based rules or further decisions of treaty bodies, in the least - by recommendations or 'soft law, ${ }^{68}$.

This position can hardly be accepted. Setting aside the general issues of the efficiency of international law of custom, it should be noted that in regard to the studied norm, at least in the western doctrine, its customlegal form is quite preferable. The discussions revolve mostly around the question whether the human right to a favorable environment has taken the shape of an international custom or not, and, one must note, neither position is prevailing here.

Not a few scientists believe that maintaining the existence of this custom is too early, although its creation process is certainly underway. In

${ }^{67}$ Weiss E.B., supra at p. 24; D.K. Anton \& D.L. Shelton, Environmental Protection and Human Rights. USA, NY: Cambridge University Press, 2011, pp. 63, 64.

${ }^{68}$ Medvedieva M.O., Specific features of creating international legal custom and treatybased rules in environmental protection. Bulletin of the Kiev National University named after T.G. Shevchenko: International relations, 2013, № 1 (40), p. 67; M.O. Medvedieva, Theoretical and practical aspects of realization of international legal norms in environmental protection, 2012, pp. 72-80. 
this connection, B. Lewis argues that, for one thing, it is still impossible to adequately outline the scope of this right, and, for another thing, there is no sufficient evidence of its opinio juris, i.e. recognition of its legally binding nature - a subjective element of a custom. Establishing the norm in international political documents and in multiple national constitutions is not enough. It should be enshrined in law and made a wide use of in the national courts ${ }^{69}$. B.H. Weston and D. Bollier, among the reasons impeding the recognition of 'a global international law right to environment', indicate: a) occurrence of this practice mainly in developing countries rather than in the advanced ones, and b) a trend of the African and Latin-American regional systems to protect the environmental rights of their native population ${ }^{70}$.

Of those who are positive as to sufficiency of evidence of the customary norm maturity, L. Horn takes a notable stand. Referring to numerous regional and national documents that reproduce the right to a favorable environment in one form or another, she asserts that in the past twenty years it has matured as an international legal custom ${ }^{71}$.

On the whole, sharing the views of supporters of the existence of international legal customary norm of the human right to a favorable environment, however, with due regard to the above criticism, we deem it necessary to make some clarifications.

Let us start with the scope of the norm. As discussed previously, thanks to the UN Human Rights Council it got its clear and correct wording - the right to enjoyment of a safe, clean and sustainable environment. Each of the words has its own subject matter which is evident both in terms of its ordinary meaning (as required by para. 1 Art. 31 of the Vienna Convention on the Law of Treaties, dated 1969), and from the perspective of its extensive interpretation with regard to practical needs. All the previous versions of this right wording contribute in a natural way the accumulated international and domestic experience of interpreting its various aspects. The norm has not appeared out of the blue. It has a background that fully conforms to a general idea of forming international legal customs. Actually, some scientists claimed as far back as in the early 1980s that there are reasons to acknowledge a broad

\footnotetext{
${ }^{69}$ Lewis B., supra at pp. 39-43.

${ }^{70}$ Weston B.H. \& Bollier D., supra at p. 15, at: http://commonslawproject.org/sites/ default/files/Regenerating\%20Essay\%2C\%20Part\%20I.pdf.

${ }^{71}$ Horn L., supra at p. 236.
} 
international recognition of this right, and notably in its shortest wording 'the right to the environment, ${ }^{72}$.

Needless to say that we agree with B. Lewis's point about the need for a wider implementation of the norm in the national law of as many states as possible, and in their court practice. However, a huge political and social consensus on it, laid down in multiple constitutional acts, is, to our mind, a valid evidence of the norm existence as an international legal custom. Additionally, J.H. Knox, Special Rapporteur of the UN Human Rights Council on this topic, states that, according to his estimates, constitutions of more than ninety (!) states establish directly the right to a healthy environment. He writes that this right is also included into regional human rights documents in Africa, Americas and in other places. Moreover, regional human rights courts apply universally recognized human rights, including the rights to life, health, and property, to consideration of environmental protection issues $^{73}$.

As for the scale of the practice, necessary for forming an international legal custom, we are fully supportive of the opinion D.K. Anton and D. Shelton in that the process of forming international legal customs in international environmental law is no different from the processes of custom formation in other international law areas. The practice, as the researchers rightly note, should not necessarily be universal in the sense that all the states on the globe must participate in $i t^{74}$. It is even less appropriate in this case to differentiate between the practice of advanced and developing states.

\section{CONCLUSIONS}

It can be said that the right to a favorable environment has already established itself as a norm of general customary international law. In spite of the scientific debates still in progress about its legal nature as a social origin of its binding power, an obvious consensus has been reached at the highest political level as regards a social significance of this right,

\footnotetext{
${ }^{72}$ Marks S.P., Emerging Human Rights: A New Generation for the 1980s? Rutgers Law Review, 1981, Vol. 33, pp. 442-444.

73 Knox J.H., Human Rights, Environmental Protection, and the Sustainable Development Goals, Washington International Law Journal, June 2015, Vol. 24, No. 3, pp. 519-520.

${ }^{74}$ Anton D.K. \& Shelton D. L., Environmental Protection and Human Rights, 2011, p. 62 .
} 
its close connections with other generally recognized human rights and freedoms of different generations that have developed universal and regional organizational and legal protection mechanisms.

Thanks to a number of international conferences held under UN auspices and an active position of the UN Human Rights Council, occupied by it since 2012, the norm has acquired a more elaborate wording that covers all the previous definitions of the right, specifically 'the right to enjoyment of a safe, clean, healthy and sustainable environment'. To our mind, this wording offers better opportunities for international and national practical activities on the legal protection of persons who suffered from violation of the right which it embodies.

Besides, this norm may entail unification of the relevant provisions contained in constitutions and regulatory acts of many states. In particular, it can also affect the norm set out in Art. 50 of the Constitution of Ukraine, providing for the human right to an environment that is safe for human life and health. Even though the sphere of relations that it regulates to a large extent corresponds to the sphere of relations regulated by international legal norm, it can be completed by targeted large-scale long-term prospects of preservation of the environment in the context of its sustainable development.

\section{SUMMARY}

The article explores the history of the development of content and formalization in today's general international law of the norm on the human right to a favorable environment. In the study of internationally known UN documents on the protection of the environment (Stockholm Declaration 1972, World Nature Charter 1982, Rio Declaration on Environment and Development 1992, Johannesburg Declaration 2002, etc.) and the analytical reports on this subject (Brundtland Report 1987, the report of Ksentini 1994, the reports of JH Knox presented to the UN Human Rights Council from 2012 to 2017), the authors of the article focused on the development of the process of individualization this right. Particular attention is paid to the analysis of documents adopted by the UN Human Rights Council from 2012 to the present. According to the authors, they allow, first, to give a more precise formulation of this right as the right to use a safe, clean, healthy and sustainable environment, and, secondly, to assert the formalization of this right as a universal international legal custom. 


\section{REFERENCES}

1. Weston B.H. \& Bollier D., supra at p. 15, at: http://commonslawproject.org/sites/default/files/Regenerating\%20Essay\% 2C\%20Part\%20I.pdf.

2. Lewis B., Environment Rights or A Right to the Environment? Exploring the Nexus between Human Rights and Environment Protection, Macquarie Journal of International and Comparative Environment Law, 2012, Vol. 8 (1), pp. 44-45.

3. Weiss B., The Evolution of International Environmental Law, Japanese Yearbook of International Law, 2011, p. 6.

4. Boyle A., Human Rights and the Environment: Where Next? European Journal of International Law, 2012, Vol. 23, P. 627.

5. Case of Kyrtatos v. Greece (Application No. 41666/98), Judgment, 22 May 2003.

6. Constitution of the World Health Organization, at: http://apps.who.int/gb/bd/PDF/bd48/basic-documents-48th-editionru.pdf?ua=1\#page=9 [in Russian].

7. García D.I. San José, Environment Protection and the European Convention on Human Rights, Council of Europe Publishing, 2005, pp. 7-11.

8. Anton D.K. \& Shelton D.L., Environmental Protection and Human Rights, 2011, p. 62.

9. Shelton D., Human Rights, Environmental Rights and the Right to Environment, Stanford Journal of International Law, 1991, Vol. 28, p. 111.

10.Weiss E.B., supra at p. 24; Anton D.K. \& Shelton D.L., Environmental Protection and Human Rights. USA, NY: Cambridge University Press, 2011, pp. 63-64.

11.Nkusi F.K., A Right to Healthy Environment: The Nexus between Environmental Protection and Human Rights, East African Journal of Science and Technology, 2015, Vol. 5, Issue 1, p. 222.

12. Gabčíkovo-Nagymaros Project (Hungary/Slovakia), Judgment of 25 September 1997, Separate Opinion of Vice-President Weeramantry, I.C.J. Reports, 1997, pp. 91-92.

13. Weston H. \& Bollier D., Regenerating the Human Right to a Clean and Healthy Environment in the Commons Renaissance. Essay, Version 1.0., September 2011, P. 74, at: http://commonslawproject.org/ sites/default/files/Regenerating\%20Essay\%2C\%20Part\%20I.pdf.

14. Human Rights and the Environment. Final Report prepared by Special Rapporteur Mrs Fatma Zohra Ksentini (E/CN.4/Sub.2/1994/9, 
Russian) of 6 July 1994. UN Economic and Social Council. Commission on Human Rights. The Sub-Commission on the Prevention of Discrimination and Protection of Minorities. Session 46. Para. 4 of Preliminary agenda, $121 \mathrm{p}$. at: https://digitallibrary.un.org/record/226681/ files/E_CN.4_Sub.2_1994_9-RU.pdf?version=1 [in Russian].

15. Knox J.H., Human Rights, Environmental Protection, and the Sustainable Development Goals, Washington International Law Journal, June 2015, Vol. 24, No. 3, pp. 519-520.

16. Horn L., The Implications of the Concept of Common Concern of a Human Kind on a Human Right to a Healthy Environment, Macquarie Journal of International and Comparative Environment Law, 2004, Vol. 1, p. 239.

17. Schwartz M.L., International Legal Protection for Victims of Environmental Abuse. Yale Journal of International Law, 1993, Vol. 18, Issue 1, Art. 15, p. 374.

18. Mushak N.B., Conceptual approaches to classification of human rights under globalization processes, Chasopys Kyivskoho universytetu prava, 2011, No 2, p. 300) [in Ukrainian].

19. Malanczuk P., Akehurst's Modern Introduction to International Law, 1997, p. 207-208; M. N. Shaw, International Law, 2008, pp. 533, 534.

20. Report of the Independent Expert on the issue of human rights obligations relating to the enjoyment of safe, clean, healthy and sustainable environment John H. Knox. Preliminary report of 24 December 2012 (A/HRC/22/43, Russian) / Human Rights Council. Session 22, at: https://documents-dds-ny.un.org/doc/UNDOC/GEN/G12/ 189/74/PDF/G1218974.pdf?OpenElement [in Russian]

21. Report of the Independent Expert on the issue of human rights obligations relating to the enjoyment of safe, clean, healthy and sustainable environment John H. Knox. Analytical report of 30 December 2013 (A/HRC/25/53, Russian) / Human Rights Council. Session 25, at: http://www.ohchr.org/EN/HRBodies/HRC/RegularSessions/Session25/Do cuments/A-HRC-25-53_ru.doc [in Russian]

22. Report of the Independent Expert on the issue of human rights obligations relating to the enjoyment of safe, clean, healthy and sustainable environment, John H. Knox, Compilation of good practices, 3 February 2015 (A/HRC/28/61) / Human Rights Council. Session 28, at: http://www.ohchr.org/EN/HRBodies/HRC/RegularSessions/Session28/Do cuments /A_HRC_28_61_EN.doc [in Russian] 
23. Report of the Independent Expert on the issue of human rights obligations relating to the enjoyment of safe, clean, healthy and sustainable environment, John H. Knox, 1 February 2016 (A/HRC/31/52, Russian) / Human Rights Council. Session 31, at: http://www.ohchr.org/ EN/HRBodies/HRC/RegularSessions/Session31/Documents/A\%20HRC\% 2031\%2052_R.docx [in Russian]

24. Report of the Independent Expert on the issue of human rights obligations relating to the enjoyment of safe, clean, healthy and sustainable environment, 28 December 2015 (A/HRC/31/53, Russian) / Human Rights Council. Session 31, at: https://documents-dds-ny.un.org/doc/UNDOC/GEN/ G15/292/98 /PDF/G1529298.pdf?OpenElement [in Russian]

25. Report of the Independent Expert on the issue of human rights obligations relating to the enjoyment of safe, clean, healthy and sustainable environment, 19 January 2017 (A/HRC/34/49, Russian) / Human Rights Council. Session 34, at: https://documents-ddsny.un.org/doc/UNDOC/GEN/G17/010/01/PDF/G1701001.pdf?OpenElem ent [in Russian].

26. Report of the Independent Expert on the issue of human rights obligations relating to the enjoyment of safe, clean, healthy and sustainable environment John H. Knox. Preliminary report of 24 December 2012 (A/HRC/22/43, Russian). Human Rights Council. Session 22, pp. 6-8, at: https://documents-dds-ny.un.org/doc/ UNDOC/GEN/G12/189/74/PDF/G1218974.pdf?OpenElement [in Russian].

27. Report of the Office of the United Nations High Commissioner for Human Rights on the Relationship between Climate Change and Human Rights of 15 January 2009 (A/HRC/10/61, Russian), at: https:// documents-dds-ny.un.org/doc/UNDOC/GEN/G09/103/46/PDF/G0910346. pdf? OpenElement; Analytical study of Relationship between Human Rights and the environment. Report of the United Nations High Commissioner for Human Rights of 16 December 2011 (A/HRC/19/34, Russian), at: http://www.ohchr.org/Documents/HRBodies/HRCouncil/RegularSession/ Session19/A-HRC-19-34_ru.pdf [in Russian].

28. Report of the United Nations Conference on Environment and Development. Rio de Janeiro, 3-14 June 1992 V. I: Resolutions adopted at the Conference (A/CONF.151/26/Rev.1(Vol.1)), UN, New-York, 1993, p. 11 [in Russian].

29. Report to the UN General Assembly of the World Commission on Environment and Development "Our Common Future" of 4 August 1987 
(Doc. A/42/427, Russian), 411 p., at: http://www.un.org/ru/ga/pdf/ brundtland.pdf [in Russian].

30. Resolution of Human Rights Council 19/10 "Human Rights and the Environment" of 22 March 2012. General Assembly. Official reports. Session 67. Annex No 53 (A/67/53, Russian). Report of Human Rights Council. UN, New York, 2012, pp. 42-45, at: https:// documents-dds-ny.un.org/doc/UNDOC/GEN/G12/161/19/PDF/G1216119. pdf?OpenElement [in Russian]

31. Resolution of Human Rights Council 25/21 "Human Rights and the Environment" of 28 March 2014. General Assembly. Official reports. Session 69. Annex No 53 (A/69/53, Russian). Report of Human Rights Council. UN, New York, 2014, pp. 101-104, at: https:// documents-dds-ny.un.org/doc/UNDOC/GEN/G14/142/70/PDF/G1414270. pdf?OpenElement [in Russian]

32. Resolution of Human Rights Council 26/27 "Human Rights and the Environment" of 27 June 2014. General Assembly. Official reports. Session 69. Annex No 53 (A/69/53, Russi"Human Rights and the Environment" of an). Report of Human Rights Council. UN, New York, 2014, pp. 243-247, at: https://documents-dds-ny.un.org/doc/UNDOC/ GEN/G14/142/70/PDF/G1414270.pdf? OpenElement [in Russian]

33. Resolution of Human Rights Council 28/11 "Human Rights and the Environment" of 26 March 2015. General Assembly. Official reports. Session 70. Annex No 53 (A/70/53, Russian). Report of Human Rights Council. UN, New York, 2015, pp. 75-78, at: https:// documents-dds-ny.un.org/doc/UNDOC/GEN/G16/196/01/PDF/G1619601. pdf?OpenElement [in Russian]

34. Resolution of Human Rights Council 31/8 "Human Rights and the Environment" of 23 March 2016. General Assembly. Official reports. Session 71. Annex No 53 (A/71/53, Russian). Report of Human Rights Council. UN, New York, 2016, pp. 58-61, at: https:// documents-dds-ny.un.org/doc/UNDOC/GEN/G16/196/01/PDF/G1619601. pdf?OpenElement [in Russian]

35. Resolution of Human Rights Council 32/33 "Human Rights and the Environment" of 1 July 2016. General Assembly. Official reports. Session 71. Annex No 53 (A/71/53, Russian). Report of Human Rights Council. UN, New York, 2016, pp. 334-339, at: https:// documents-dds-ny.un.org/doc/UNDOC/GEN/G16/196/01/PDF/G1619601. pdf?OpenElement [in Russian] 
36. Resolution of Human Rights Council 34/20 "Human Rights and the Environment" of 24 March 2017. General Assembly. Official reports. Session 72. Annex No 53 (A/72/53, Russian). Report of Human Rights Council. UN, New York, 2017, pp. 108-112, at: https:// documents-dds-ny.un.org/doc/UNDOC/GEN/G16/196/01/PDF/G1619601. pdf?OpenElement [in Russian]

37.Glazebrook S., Human Rights and the Environment. Victoria University of Wellington Law Review, 2009, Vol. 40, p. 317.

38. Kravchenko S. \& Bonine J.E., Interpretation of Human Rights for the Environment in the European Court of Human Rights, Global Business \& Development Law Journal, 2012, Vol. 25, p. 245-287.

39. Kravchenko S. \& Bonine J.E., supra at pp. 245-287.

40. Marks S.P., Emerging Human Rights: A New Generation for the 1980s? Rutgers Law Review, 1981, Vol. 33, pp. 442-444.

41.The Outcome Document of the United Nations Conference on Sustainable Development in Rio de Janeiro (20-22 June 2012): Draft Resolution submitted by President of the General Assembly, "The future we want" (A/66/L.56, Russian), 24 July 2012, at: https://documents-ddsny.un.org/doc/UNDOC/LTD/N12/436/90/PDF/N1243690.pdf?OpenElem ent [in Russian].

42. Universal Declaration of the Rights of Mother Earth, 28 April 2010 (Cochabamba, Bolivia), at: http://www.rightsofmotherearth.com/ универсальная-декларация-прав-матери-земли [in Russian].

43. Getman A.P. \& Kostytskyi V.V., Human environmental rights in the national and international legal doctrine, Problems of Legality, 2013, Issue 124, p. 78 [in Ukrainian].

44. Solntsev A.M., Protection of Environmental Human Rights, 2015, p. 25 [in Russian]

45.Kopylov M.N., Kopylov S.M. \& Mishlanov V.A., International Environmental Law is 175, Moscow Journal of International Law, 2014, № 1 (93), p. 104 [in Russian].

46. Medvedieva M.O., Specific features of creating international legal custom and treaty-based rules in environmental protection. Bulletin of the Kiev National University named after T.G. Shevchenko: International relations, 2013, № 1 (40), p. 67.

47. Medvedieva M.O., Theoretical and practical aspects of realization of international legal norms in environmental protection, 2012, pp. 72-80. 
48. Miroshnychenko O.A., Human Right to Life (theory and practice of international cooperation). Extended abstract of candidate's thesis, 2005, p. 12 [in Ukrainian].

49. Korotkiy T.R., Ecologization of international law in the light of environmental human rights, p. 134, at: http://archive.nbuv.gov.ua/portal/ Soc_Gum /App/2012_44/Korotkiy.pdf) [in Russian].

Information about the authors: Getman A. P., Doctor of Legal Sciences, Professor,

Vice-Rector for Scientific Work, Yaroslav Mudryi National Law University ORCID: 0000-0002-1987-2760

Shchokin Y. V., Doctor of Legal Sciences, Associate Professor of International Law Department, Yaroslav Mudryi National Law University ORCID: 0000-0002-8082-2367

Hetman Y. A., Doctor of Legal Sciences, Senior Research Fellow, National Academy of Legal Sciences of Ukraine ORCID: 0000-0002-1801-7252 


\title{
IMPACT OF THE ENVIRONMENTAL LAW DOCTRINE ON THE DEVELOPMENT OF THE STATE ENVIRONMENTAL POLICY AND LAWS
}

\begin{abstract}
Anisimova H. V.
\end{abstract}

\section{INTRODUCTION}

The urgent objective of the modern legal science is to develop a coherent, logically consistent national legal doctrine (and its integral component of environmental law doctrine) as the theoretical basis of the regulation processes, and to form a single legal space and its component of the environmental law space. However, it should be borne in mind that in the EU it was a complex, long-lasting and gradual process, especially in view of the fact that in accordance with the international commitments the common values on the basis whereof the European Union was built, namely democracy, rule of law, respect for human rights and fundamental freedoms, compliance with the standards of the European security system should remain unchanged by virtue of the fact that it is the desire of the Ukrainian society.

The priority of the issue under consideration is confirmed by the theoretical and practical significance of the formulation of such legal categories as "environmental law doctrine", "environmental law", and "state environmental policy" due to which the scientific doctrine of the essence and content of environmental law is expanded, its interaction with other legal branches and sciences not only of legal orientation, the influence on the development of environmental laws in the conditions of sustainable development and European integration processes and the experience of the application thereof, the interpretation of the environmental law rules is improved, and the formation of the modern State Environmental Policy of Ukraine is accelerated. The aforesaid categories contribute to the formation of a legal model of understanding and interpretation of environmental relationship.

It is pertinent to cite V. I. Andreitsev's remarks regarding the fact that scientific doctrines, which are based on the requirements of the applicable environmental laws, tendencies of its improvement and conceptual ideas of some scientific schools, do not take into account the whole range of legislative regulation of environmental relations, which introduces the relevant balance and discipline, the purpose whereof is the formation of 
specialists in the legal profile of different environmental law worldviews and legal thinking ${ }^{1}$.

\section{Environmental law doctrine: scientific approaches to its interpretation}

In the environmental law science (as in all jurisprudence), the term "doctrine" is now widely used. Despite the level and the soundness of the research, there is still not only unanimous opinion on the essence of the concept of "doctrine" and its functions, but also on its place in the system of sources (forms) of law. This, in turn, causes difficulties in the study of the environmental law system, as well as its place in the legal system. We support the conclusions made by Yu. S. Shemshuchenko and A. P. Hetman that the implementation of doctrinal provisions by state construction and legal practice is important for the improvement of law enforcement and, in fact, the legal life of the society, the adaptation of law to modern social and economic and political conditions ${ }^{2}$. According to M. V. Karmalita, legal doctrine, embodying legal ideas, concepts and principles, improves the applicable laws ${ }^{3}$.

Formation of the modern environmental law doctrine (types of concepts) as sector on the defining provisions of legal doctrine (generic concept) is caused by the global environmental crisis related to the depletion of natural resources, pollution of the environment, failure to comply with the requirements of environmental safety in conducting economic activity with waste, etc. In view of all the foregoing, the international community at the end of the twentieth century has chosen a new paradigm for sustainable development, which still remains relevant, and the issue of forming a new international environmental law is not only an increase in the number of environmental agreements, regulations at the national level, but also an improvement in the quality of the national system of environmental laws, which is not perfect. Many of its acts do not meet the current environmental law doctrine, European trends in the development of Ukrainian statehood and the requirements of today.

${ }^{1}$ Правова доктрина України : монографія : у 5 т. Т. 4 : Доктринальні проблеми екологічного, аграрного та господарського права / Ю.С. Шемшученко, А.П. Гетьман, В.І. Андрейцев та ін. ; за заг. ред. Ю.С. Шемшученка. Харків : Право, 2013. С. 97.

${ }^{2}$ Правова доктрина України : монографія : у 5 т. Т. 4 : Доктринальні проблеми екологічного, аграрного та господарського права / Ю.С. Шемшученко, А.П. Гетьман, В.І. Андрейцев та ін. ; за заг. ред. Ю.С. Шемшученка. Харків : Право, 2013. С. 7.

${ }^{3}$ Кармаліта М.В. Правова доктрина - джерело (форма) права : автореф. дис. ... канд. юрид. наук. Київ, 2011. С. 1. 
The scientific and theoretical basis for the study of the legal category "doctrine" is the work of scientists of pre-revolutionary, Soviet and modern periods in various fields of scientific knowledge, concerning theoretical models and concepts, devoted to methodological grounds of legal doctrine, comparative law, theory and philosophy culture, sources of law, including: S. S. Aleksieiev, J. G. Berman, M. I. Baitin, A. I. Bobyliov, S. V. Boshno, A. O. Vasyliev, S. P. Golovatyi, R. David, Yu. A. Zadorozhnyi, O. O. Zozulia, O. S. Ioffe, M. V. Karmalita, D. A. Kerymov, A. A. Kozlovskyi, M. I. Koziubra, M. M. Korkunov, S. I. Maksymov, M. M. Marchenko, M. I. Matuzov, M. E. Mochulska, V. S. Nersesiants, N. M. Onishchenko, N. M. Parkhomenko, I. F. Pokrovskyi, P. M. Rabinovych, I. V. Semenikhin, etc.

The environmental and legal aspects of the development of legal doctrine were the object of study V. I. Andreitsev, H. I. Baliuk, A. H. Bobkova, A. P. Hetman, P. A. Hvozdyk, T. H. Kovalchuk, M. E. Kovalska, V. V. Kostytskyi, S. M. Kravchenko, M. V. Krasnova, P. F. Kulynych, N. R. Malysheva, V. L. Muntian, V. V. Nosik, V. K. Popov, B. H. Rozovskyi, Yu. S. Shemshuchenko, A. S. Shesteriuk, M. V. Shulga, etc.

A significant contribution to the disclosure of the philosophical and legal, methodological and scientific principles of jurisprudence, doctrinal dimensions of the rule of law, human rights, legal system, doctrinal concepts of modern Ukrainian statehood and historical and legal doctrines was made by the collective of authors of the monograph "General Theoretical and Historical Jurisprudence" of the five-volume "Legal Doctrine of Ukraine" . In the "Great Ukrainian Legal Encyclopedia" legal doctrine is regarded as "stipulated by the nature of the legal culture of society a holistic and logically consistent set of ideas and scientific views on the right, which serves as the basis of professional justice and the conceptual basis of rulemaking, law enforcement, and interpretation operations". The legal doctrine is a product of scientific activity, a kind of summary of knowledge of state reality in a specific historical period ${ }^{5}$.

${ }^{4}$ Правова доктрина України : монографія : у 5 т. Т. 1 : Загальнотеоретична та історична юриспруденція / В.Я. Тацій, О.Д. Святоцький, С.І. Максимов та ін. ; за заг. ред. О.В. Петришина. Харків : Право, 2013.976 с.

${ }^{5}$ Велика українська юридична енциклопедія : у 20 т. Т. 3 : Загальна теорія права / редкол.: О.О. Петришин (голова) [та ін.] ; Нац. акад. прав. наук України, Ін-т держави і права ім. В.М. Корецького НАН України ; Нац. юрид. ун-т ім. Ярослава Мудрого. Харків : Право, 2017. С. 471. 
The opinion of H. I. Baliuk that environmental law science is no exception should be supported ${ }^{6}$. At the same time, as noted, the development of science is not only a process of quantitative accumulation of knowledge about any phenomenon, but also an evolutionary transition to the realization of its new quality. As of today, the authors of the section of the monograph "Doctrinal Problems of Environmental, Agrarian and Business Law" of the aforementioned five volumes have applied the most systematic approach to study the doctrine of the modern environmental law of Ukraine in the 20th - 21st centuries. The modern doctrine of environmental law and laws, already presented by scientists ${ }^{8}$, is based on the principles of market economy, European integration processes, achievement of sustainable development for our country, in order to ensure in the environmental law field the priority of human and citizen's rights and freedoms, rule of law, transparency and openness activities of both state and local government authorities and civil society organizations, establishing constructive interaction between them, increasing their responsibility, implementation of the state and regional environmental policies and resolving local issues, etc.

As V. I. Andreitsev notes, scientific legal doctrines were formed and legalized under the existing mechanism of legal regulation with all its progressive and regressive ideas, regulations, and attitudes towards carrying out various activities that would be compatible with the principles of the relevant environmental policy. That is why doctrinal approaches should be adequate to the content of the latter, with certain elements of scientific predictability for the future, since environmental law science is characterized by a predictive function ${ }^{9}$. On the basis

${ }^{6}$ Балюк Г.І. Роль доктрини екологічного права в започаткуванні і розвитку ядерно-правових досліджень в Україні. Правова доктрина України : монографія : у 5 т. Т. 4 : Доктринальні проблеми екологічного, аграрного та господарського права / Ю.С. Шемшученко, А.П. Гетьман, В.І. Андрейцев та ін. ; за заг. ред. Ю.С. Шемшученка. Харків : Право, 2013. Підрозд. 1.7. С. 252.

7 Правова доктрина України : монографія : у 5 т. Т. 4 : Доктринальні проблеми екологічного, аграрного та господарського права / Ю.С. Шемшученко, А.П. Гетьман, В.І. Андрейцев та ін. ; за заг. ред. Ю.С. Шемшученка. Харків : Право, 2013. 848 с.

8 Гетьман А.П. Доктрина екологічного права та законодавства України : монографія. Харків : ТОВ “Оберіг”, 2019. 336 с. (Харківська наукова школа екологічного права).

9 Андрейцев В.I. Інкорпорація як важлива форма систематизації екологічного законодавства. Правова доктрина України : монографія : у 5 т. Т. 4 : Доктринальні проблеми екологічного, аграрного та господарського права / Ю.С. Шемшученко, А.П. Гетьман, В.І. Андрейцев та ін. ; за заг. ред. Ю.С. Шемшученка. Харків : Право, 2013. Підрозд. 1.4. С. 98. 
thereof, V. I. Andreitsev proposed the author's definition of the scientific doctrine of environmental law - a system of logical and consistent scientific provisions, principles of justification and prediction of the scientist (scientists), formulated on the basis of analysis, synthesis, other methods of scientific research, generalizations and conclusions about genesis, the status and development of environmental law and legislation, their constituents and elements (industries, sub-sectors, institutes, super-institutes), which, based on progressive methodological principles, proves (proposes and approves) new scientific approaches to the legal understanding and legal realization of environmental legal relationships or their sectors with respect to the maintenance and guarantee of the legal personality of participants in these legal relationship ${ }^{10}$.

In view of the definition of V. I. Andreitsev, the sector environmental law doctrine is the result of environmental-legal scientific researches based on interdisciplinary approaches to the science of environmental law. As new knowledge, the doctrine acquires the status of scientific under the conditions of compliance with two requirements: scientific validity (authenticity) and formal-logical conformity to the general initial principles and laws of legal science ${ }^{11}$.

Pursuant to Article 8 of the Law of Ukraine "On Environmental Protection" dated June 25, 1991 No. 1264-XII ${ }^{12}$ the systematic complex scientific researches of the environment and natural resources are made in the state for the purpose of developing the scientific bases for the protection thereof and rational use and ensure environmental safety. The results thereof are coordinated and exposed to synthesis by the NAS of Ukraine and the central executive authority, which implements state policy in the field of environmental protection. Furthermore, the grounds for the further development of the modern environmental science are the laws of Ukraine "On Scientific and Technical Operations" dated

${ }^{10}$ Андрейцев B.I. Наукова доктрина - методологія пізнання та удосконалення екологічного права та практики його застосування. Сучасні науково-практичні проблеми екологічного, земельного та аграрного права : матеріали круглого столу (м. Харків, 6 груд. 2013 р.) / за заг. ред. А.П. Гетьмана. Харків : Право, 2013. С. 12.

11 Мочульська М.Є. Правова доктрина в континентальній правовій системі : автореф. дис. ... канд. юрид. наук. Львів, 2011. С. 8.

12 Про охорону навколишнього природного середовища : Закон України від 25.06.1991 № 1264-XII. URL: http://zakon5.rada.gov.ua/laws/show/1264-12 (date of access: 28.01.2020). 
November 26, 2015 No. 848-VIII ${ }^{13}$, “ On Higher Education” dated July 1, 2014 No. 1556-VII ${ }^{14}$, "On Basic Principles (Strategy) of the State Environmental Policy of Ukraine for the period up to 2030 dated February 28, 2019 No. 2697-VIII" ${ }^{15}$, and the Presidential Decree "On the Strategy for Sustainable Development" Ukraine 2020" dated January 12, 2015 , No. $5 / 2015^{16}$ etc. All of the aforesaid acts are aimed at improving and increasing the science level, including the social sciences and humanities, whereas the environmental science is an integral part thereof. The objective of the latter is to develop and systematize the environmental laws by taking into account the influence of social, economic, political and international factors. However, despite the adoption of the Law of Ukraine "On Scientific and Scientific and Technical Operations' dated November 26, 2015 No. 848-VIII ${ }^{17}$, the purpose whereof is to modernize the legislative support of the field of scientific and scientific-technical operations, to provide conditions for increasing the efficiency of scientific research and use the results thereof to ensure the development of all spheres of public life, the implementation of its regulations is extremely slow. Certainly, the Law: a) provides access to research funding not only for specific institutions, but also for teams of scientists and even individual scientists; b) change the whole system of financing such research; c) increase a part of the grant funding, which will be distributed through the National Research Fund of Ukraine ${ }^{18}$; d) grants priorities to the development of research at universities; e) involves the participation of young scientists in the formation of scientific and scientific-technical policy; f) introduces a rule that state scientific institutions and state

13 Про наукову і науково-технічну діяльність : Закон України від 26.11.2015 № 848-VIII. URL: http://zakon5.rada.gov.ua/laws/show/848-19 (date of access: 27.01.2020).

14 Про вищу освіту : Закон України від 01.07.2014 № 1556-VII. URL: https://zakon.rada.gov.ua/laws/show/1556-18 (date of access: 27.01.2020).

15 Про Основні засади (стратегію) державної екологічної політики України на період до 2030 року : Закон України від 28.02.2019 № 2697-VIII. URL: https://zakon.rada.gov.ua/laws/show/2697-19 (date of access: 27.01.2020).

16 Про Стратегію сталого розвитку “Україна-2020” : затв. Указом Президента України від 12.01.2015 № 5/2015. URL: http://zakon2.rada.gov.ua/ laws/show/5/2015 (date of access: 28.01.2020).

17 Про наукову і науково-технічну діяльність : Закон України від 26.11.2015 № 848-VIII. URL: http://zakon5.rada.gov.ua/laws/show/848-19 (date of access: 27.01.2020).

18 Про Національний фонд досліджень України : Постанова Каб. Міністрів України від 04.07.2018 № 528. URL: http://zakon.rada.gov.ua/laws/show/ru/528-2018-\% D0\%BF (date of access: 27.01.2020). 
universities, academies, institutes are entitled to co-founders of companies for the purpose of using the objects of intellectual property rights. However, it is difficult to achieve this quickly, and therefore much remains to be done for the effective operation of this Law.

Since 01.01.2021 the Law of Ukraine "On Fundamental Principles (Strategy) of the State Environmental Policy of Ukraine for the Period up to 2030" came into force, which defines the vectors for reforming modern environmental laws. Undoubtedly, the ambiguous (and in some cases almost negative) attitude to the principles of modern state environmental policy has become well known. It should be noted that in accordance with the resolution of the Verkhovna Rada of Ukraine (dated September 18, 2019), on November 27, 2019, the parliamentary hearings were held on "Priorities of environmental policy of the Verkhovna Rada of Ukraine for the next five years" with the participation of representatives of central and local executive authorities, authorities local self-government, nongovernmental organizations, scientific institutions. Wherein proposals of the Cabinet of Ministers of Ukraine and the Ministry of Energy and Environmental Protection of Ukraine were published (Letters dated 28.10.2019 No. 23973/0/2-19 and No. 5/4-10/11699-19). First of all, it is a matter of submitting to the Verkhovna Rada of Ukraine a number of draft laws of Ukraine. In which, taking into account the processes of globalization and social transformation, urgent measures are proposed. It is proposed to adopt laws: "On the Principles of Monitoring, Reporting and Verification of Greenhouse Gas Emissions"; "On Ozone-Depleting Substances and Fluorinated Greenhouse Gases"; "On Ratification of the Kigali Amendment to the Montreal Protocol"; "On Waste Management"; "On Chemical Safety"; "Ratification of the Nagoya Protocol on Access to Genetic Resources and the Equitable and Equitable Sharing of Benefits from their Use to the Convention on Biological Diversity"; "On the State Biosafety System for the Creation, Testing, Transportation and Use of Genetically Modified Organisms" (revised); "On the Ratification of the Nagoya-Kuala Lumpur Additional Protocol on Liability and Compensation to the Cartagena Protocol on Biosafety"; a new wording of the Subsoil Code; "On Amendments to Some Legislative Acts of Ukraine on Improvement of Environmental Laws", etc.

We should add that now it is required to take into account the fact that the limits of international cooperation, established by the Agreement between Ukraine and the European Community on scientific and technological cooperation, will allow to reach the goal faster - gradual approximation of Ukraine to the EU policy and law in this sphere and 
involvement of our country to the European Research Area, which is also provided for in the Association Agreement between Ukraine, on the one hand, and the European Union, the European Atomic Energy Community and their Member States, on the other hand (hereinafter referred to as - the Association Agreement). In view of all the aforesaid facts, O. O. Orendarets regards the objective of the science of environmental law today in the substantiation of the modern concept and doctrine of the development of environmental law in the conditions of economic and social present, priority directions of legislative activity in this sphere of public relations for the near and distant perspective, systematics in development and adoption of environmental laws in the light of economic, social, international and political challenges ${ }^{19}$. V. I. Andreitsev hereby states in view of the foregoing that environmental-legal science should still precede the creation of scientific doctrines and concepts of the development of environmental laws, the formation of state environmental policy. Certainly, this fact will greatly accelerate the development of the latter, will ensure the adoption of the principles of environmental law in the practice of law, which, so to speak, "owes" it is environmental law, in particular, to determine the scientific approaches and the theoretical and practical provisions of certain scientific law schools ${ }^{20}$.

For the sake of completeness and comprehensive study of the issue, it is important that the formation of doctrines is linked to the creation of scientific schools. In the modern period, according to V. I. Andreitsev, the process of forming the latter is becoming more and more cross-sector, which is explained by the emergence of powerful scientific and coordination centers through the legalization of all-Ukrainian and international scientific structures, the leaders whereof have the opportunity to arrange for the structured mobile scientific teams around the ideas and doctrines that bring together scholars of relevant legal knowledge ${ }^{21}$. Moreover, as he continues and develops this view, S. I. Maksymov emphasizes that universal teachings acquire doctrinal nature only when they are used to solve a particular legal issue, although the aforesaid doctrines (for example, positivism and the theory of natural law, the

19 Орендарець О.О. Розвиток науки екологічного права : автореф. дис. ... канд. юрид. наук. Київ, 2015. С. 3.

${ }_{20}$ Андрейцев В.І. Екологічне право і законодавство суверенної України: проблеми реалізації державної екологічної політики : монографія. Дніпро : Нац. гірн. ун-т, 2011. $373 \mathrm{c}$.

21 Андрейцев B.I. Наукові та науково-практичні школи: стан та перспективи правового регулювання : монографія. Київ : Знання, 2009. С. 21. 
concept of the rule of law - legal states) and formulate their provisions in the abstract, in the most general form ${ }^{22}$.

At the same time, it is worth noting again that legal sources, in particular in scientific works on environmental law, have differences in the understanding of the jurisprudential nature of the doctrine, the interpretation of its essence and features. Under the current conditions in jurisprudence, the legal category "doctrine" operates in a variety of phrases: positivist, natural law doctrine of absolute sovereignty, doctrine of control over crime, doctrine of national security, doctrine of law, state and legal doctrine, legal doctrine, the doctrine (or doctrine of international law), the doctrine of globalization of human and citizen rights, the doctrine of employment, etc., which again confirms the multidimensionality of this term.

It should be noted that any doctrine is based on the idea of the nature of law, of the fact what it is. The basis of such ideas, as noted by S. I. Maksymov, are two opposing intuitions: a) law is a social fact; it is created by power-holders (such as legislators and judges) or by human habits; b) judges and law researchers gain knowledge of it through valuation operations, that is, interpretations of laws, precedents, and other sources of law. Such an interpretation is inevitably linked to justice; therefore, an unfair interpretation is wrong ${ }^{23}$.

Let's recall that the science of environmental law in its evolution has passed several stages. In addition, the achievements made during each of them allow differentiation, separation of legal institutions, sub-sectors and branches of environmental law in the process of their formation. Based on the above, we can say that the evolution of environmental law is a continuous process that reflects the dialectic of environmental relations, although it is uneven, which is due to the development of various fields of knowledge - technical and social. Equally important, however, is that the integration of different spheres of knowledge into environmental law contributes to the creation of scientifically sound environmental law doctrine, lays the foundation for the legal regulation of social relations that ensure environmental rights, environmental law, the harmonious interaction of nature and society and satisfying the interest of the parties subject to the law.

\footnotetext{
22 Андрейцев B.I. Наукові та науково-практичні школи: стан та перспективи правового регулювання : монографія. Київ : Знання, 2009. С. 63.

23 Максимов С.І. Правова доктрина: філософсько-правовий підхід. Правова доктрина України : монографія : у 5 т. / за ред. В.Я. Тація, О.Д. Святоцького, C.I. Максимова [та ін.]. Т. 1 : Загальнотеоретична та історична юриспруденція / за заг. ред. О.В. Петришина. Харків : Право, 2013. Підрозд. 1.3. С. 58-93.
} 
First of all, it is emphasized that various definitions of sources get various definitions of the category "legal doctrine", such as: a) doctrine (theory) as a set of theoretical provisions on legal phenomena; b) state program (concept) of regulation of public relations, setting goals, objectives, determining the means for the implementation thereof; c) a set of general principles, starting principles of law, supported or sanctioned by the state; d) guiding theoretical principles, basic legal definitions; e) scientific works of authoritative researchers; f) the views of legal scholars on particular issues of law-making and enforcement; g) element of the legal system, etc. As we can see, "doctrine" is a complex, comprehensive and multifaceted concept ${ }^{24}$.

The semantic analysis of the term "doctrine" enabled A. O. Vasyliev for concluding that there are two meanings as follows: a) doctrine as a teaching, text, and b) doctrine as a set of ideas supported by scholars. In the context of jurisprudence, legal doctrine means a doctrine of law and ideas endorsed and defended by the corporation. Therefore, there is an understanding of doctrine as a system of principles, perceptions, and views of nature, society and a person.

In philosophical and legal science, the term "doctrine" is usually used in the context of such concepts as "doctrine", "social science", "philosophical theory (natural law, positivist)", "ideology (liberal, socialist, conservative)", "dogma", "concept" and others. However, in all cases, as noted by S. I. Maksymov, in its application refers to the doctrine (knowledge), which is to some extent reduced to the internal consistent nucleus, which is why it is aimed at direct use in practice. General understanding of the concept of "doctrine" in the scope of legal importance acquires its specific manifestation as a legal doctrine ${ }^{25}$.

Let's consider the basic approaches to legal understanding of the category "legal doctrine". First of all, let us start from the point of view of V. V. Kopieychykov, who emphasized that legal doctrine should be considered as a set (system) of scientific knowledge about a certain legal

24 Анісімова Г. В. Вплив природно-правової концепції на розвиток екологоправової доктрини, науки та законодавства. Рівень ефективності та необхідності впливу юридичної науки на нормотворчу діяльність та юридичну практику : матеріали міжнар. наук.-практ. конф. (м. Харків, 5-6 лют. 2016 р.). Харків, 2016. C. 52 .

Максимов С.І. Правова доктрина: філософсько-правовий підхід. Правова доктрина України : монографія : у 5 т. / за ред. В.Я. Тація, О.Д. Святоцького, C.I. Максимова [та ін.]. Т. 1 : Загальнотеоретична та історична юриспруденція / за заг. ред. О.В. Петришина. Харків : Право, 2013. Підрозд. 1.3. С. 60-61. 
phenomenon. It may be developed under the appropriate conditions into a more or less generalized theory of law. The relationship between legal doctrine and legal theory is somewhat relative. If the legal doctrine covers a wide range of fundamentally important methodological issues, it may initiate the development of relevant theories of law. Mostly it is included in the theory of law as its element ${ }^{26}$.

According to N. M. Parkhomenko ${ }^{27}$, T. Ya. Khabrieva ${ }^{28}$, K. V. Romanov $^{29}$ and other jurists, the legal doctrine in its meaning is closest to legal science, and in most cases the terms "science" and "doctrine" are identical, identical terms. Doctrinal provisions are predominantly scientific in nature, but not any science is a doctrine. In legal science there are many concepts, approaches, theories, which offer different approaches (often diametrically opposite in content) to solving certain problems of legal regulation. Scientific pluralism lies in the very principle of scientific rigor. No scientific concept can claim "truth" in the last instance, and therefore presupposes that there are other points of view on the problem under study ${ }^{30}$.

\section{Environmental law doctrine as a source (form) of law}

Scholars are asked more often whether legal doctrine is the source (form) of law. It is well known that the legal systems of the world differ in the originality of sources of law, the degree of their development, the priority of some sources over others. However, in these systems, the sources of law are regulatory acts, regulatory legal agreements, legal customs, judicial precedents (or case law), general principles of law, legal doctrine. Therefore, within the Romano-German legal system, the general principles of law play an important role as an independent source of law ${ }^{31}$.

${ }^{26}$ Міжнародна поліцейська енциклопедія : у 10 т. / відп. ред. Ю.І. Римаренко, Я.Ю. Кондратьєв, В.Я. Тацій, Ю.С. Шемшученко. Т. 1 : Теоретико-методологічні та концептуальні засади поліцейського права та поліцейської деонтології. Київ : Ін Юре, 2003. C. 186.

${ }^{27}$ Пархоменко Н.М. Джерела права: проблеми теорії та методології : монографія. Київ : Юрид. думка, 2008. С. 141.

28 Хабриева Т.Я. Доктринальное значение российской Конституции. Журнал российского права. 2009. № 2. С. 34.

29 Романова Е.В. Судебная доктрина в системе источников налогового права США : автореф. дис. ... канд. юрид. наук. Москва, 2012. С. 4.

30 Семеніхін І.В. Правова доктрина: загальнотеоретичний аналіз / за ред. О.В. Петришина. Харків : Юрайт, 2012. Вип. 2. С. 26.

31 Теорія держави і права : підручник / О.В. Петришин, С.П. Погребняк, В.С. Смородинський [та ін.] ; за ред. О. В. Петришина. Харків : Право, 2014. С. 108. 
According to the jurists (and this is not in dispute), the Ukrainian legal system is referred to this type of legal system as a kind of European form $^{32}$. At the same time, the issues of the number of legal families, their groups, classes and types and their classification have been, and remain, debated. However, in the domestic scientific environment there is a crisis of the methodology of legal positivism, and this has an impact on studies that violate the problem of typology and classification of the legal system of Ukraine.

Law scholars distinguish between two basic, diametrically opposed, contradictory approaches, but this does not preclude their internal differentiation in recognizing or denying the regulatory function of legal doctrine, its ability to be a source of law. The vast majority of experts view the doctrine as a source (form) of law or as a factor that significantly influences law-making and law-enforcement practices ( A. O. Vasyliev, M. M. Voplenko, V. V. Diervoied, O. O. Zozulia, S. A. Karapetian, M. V. Karmalita, T. M. Priakhin, N. M. Parkhomenko, R V. Puzykov, I. V. Semenikhin, V. V. Sorokin, etc.). For example, O. O. Zozulia considers legal doctrine to be a general legal category that integrates a set of legal and scientific interpretations and judgments about positive law, within the scope thereof the legal forms of knowledge of law and legal phenomena, principles, concepts, terms, constructions, methods and techniques are developed and substantiated, means of understanding and interpreting positive law, its sources, systems, structures, actions and applications, violations and restoration ${ }^{33}$.

At the same time, M. V. Karmalita views legal doctrine as a source (form) of law, which contains a system of fundamental views of jurists on state-legal phenomena, scientifically substantiates socially important problems in order to more effectively solve them and outlines the strategic prospects of legal development of the state. The researcher focuses on the shortcomings of a purely positive approach to understanding the concept of "source of law" (for example, its identification with the system of sources of law), which simplified this problem and negated its importance for legal practice ${ }^{34}$. We express our solidarity with her assertion that the

32 See: Скакун О.Ф. Теория государства и права : учебник. Харьков : Консум, 2000. С. 238; Оніщенко Н.М. Правова система: проблеми теорії : монографія. Київ : Ін-т держави і права ім. В.М. Корецького НАН України, 2002. С. 110.

33 Зозуля А.А. Доктрина в современном праве : автореф. дис. ... канд. юрид. наук. Санкт-Петербург : Петербург. гуманитар. ун-т профсоюзов, 2006. С. 10.

34 Кармаліта М.В. Правова доктрина - джерело (форма) права : автореф. дис. ... канд. юрид. наук. Київ, 2011. 21 с. 
use of legal doctrine as a source of law in legal systems and the feasibility of transforming environmental law doctrine into sources of environmental law in the following cases: a) its interpretation; b) development of bills and their adoption; c) implementation of the provisions of the legal doctrine in the resolutions of the constitutional courts, their justification on the basis of the legal doctrine of judicial or administrative resolution according to the formula "in accordance with the thought ruling in the scientific literature" 35 .

Considering the features and perspectives of the development of the system of sources of law, N. M. Parkhomenko emphasizes the need for enhancing the role of legal doctrine in it, ensuring the constant feedback of legal science and practice. In her view, legal doctrine is part of the system of sources of law (its subsystem), but it does not have its own systemic structure $^{36}$. In our opinion, it is advisable to support the position of scholars who consider such a contradiction. Legal doctrine is a complex multi-structural phenomenon, the elements of which are interrelated sector legal doctrines. In the legal scientific literature in this regard, the opinion is expressed about the existence of certain subspecies (levels) of legal doctrine, which should mean sector legal doctrines ${ }^{37}$.

As S. V. Boshno rightly points out, scientific work can become doctrinal if it contains practical recommendations, comments on laws and other forms of law; predicts the processes of lawmaking and legal implementation; eliminates gaps in laws ${ }^{38}$. Other researchers are of the same opinion $^{39}$. Only a part of the scientific provisions acquires signs of

${ }^{35}$ Кармаліта М.В. Правова доктрина - джерело (форма) права : автореф. дис. ... канд. юрид. наук. Київ, 2011. С. 16-17.

${ }^{36}$ Пархоменко Н.М. Система джерел права: ознаки, властивості та зміст. Часопис Київського університету права. 2007. № 3. С. 11-12.

37 Любитенко Д.Ю. Системные свойства правовых доктрин. Вестник Владимирского юридического института. 2011. № 1. С. 140-145; Пузиков Р.В. Юридическая доктрина в сфере правового регулирования (проблемы теории и практики) : дис. ... канд. юрид. наук. Тамбов, 2003. 213 с.; Сорокин В.В. Судебная практика или правовая доктрина. Арбитражный и гражданский процесс. 2002. № 8. С. 8-11; Трофименко В.А. У пошуках ідеального джерела права: правові доктрини світу. Юридичний радник. 2007. № 4 (18). С. 82-88 тощо.

${ }_{38}$ Бошно С.В. Доктрина как форма и источник права. Журнал российского права. 2003. № 12. С. 79.

${ }^{39}$ Мочульська М.С. Правова доктрина та правова наука: співвідношення понять. Проблеми державотворення і захисту прав людини в Україні : матеріали XVIII регіон. наук.-практ. конф. (м. Львів, 26-27 січ. 2012 р.). Львів : Нац. ун-т ім. I. Франка, 2012. C. 39 . 
doctrine pattern, which receives the general recognition of the legal community, which is the basis for legitimizing the doctrine in the public consciousness, the possible official recognition of it by the state (for example, by incorporating a particular doctrinal provision into the text of the law) and the perception of its legal practice.

In connection therewith, it is advisable to give the view of M. M. Korkunov, who believed that when among lawyers on a particular issue formed a fixed view, it necessarily influences the legal practice, which takes into account it in view of scientific authority. Jurisprudence until the relevant view of the communis opinio doctorum is refuted ${ }^{40}$. In this regard, M. E. Mochulska emphasizes that only those scientific statements that are of particular scientific value and are universally recognized in the scientific community become doctrinal ${ }^{41}$. Other important scholars also pay attention to this important feature of legal doctrine.

In addition to the above, M. E. Mochulska proves that, apart from objectification in scientific works (dissertations, monographs, scientific articles, etc.), legal doctrine is embodied in various forms, the characteristics whereof are the required prerequisite for establishing its place and role in the continental legal system. As a result of the analysis of the laws, law-making and law-enforcement practices of the states within this legal system, the researcher finds out the basic forms of expression of legal doctrine, among which the legislative definitions and conclusions of scientific legal expertise deserve special attention. She hereby states that the expression of legal doctrine in the form of legislative definitions is characteristic of most states of the continental legal system (in particular, Germany, Switzerland, France, and Poland) and concludes that the general tendency is the growing role of scientific legal expertise, and therefore the implementation of legal doctrine in the form of expert opinions. Due to the pluralistic approach to the understanding of law in the continental legal system, a general and specific concept of legal doctrine is distinguished.

${ }^{40}$ Коркунов Н.М. Лекции по общей теории права. Изд. 4-е. СанктПетербург : Изд. юрид. кн. магазина Н.К. Мартынова, 1897. 354 c. URL: http://library.nlu.edu.ua/cgibin/irbis64r_01/cgiirbis_64.exe?Z21ID=\&I21DBN=IBIS\&P21DBN=IBIS\&S21STN=1\&S21

$\mathrm{REF}=3 \& \mathrm{~S} 21 \mathrm{FMT}=$ fullwebr $\& \quad \mathrm{C} 21 \mathrm{COM}=\mathrm{S} \& \mathrm{~S} 21 \mathrm{CNR}=20 \& \mathrm{~S} 21 \mathrm{P} 01=0 \& \mathrm{~S} 21 \mathrm{P} 02=0 \& \mathrm{~S} 21 \mathrm{P} 03=$ $\mathrm{M}=\& \mathrm{~S} 21 \mathrm{~S}$ TR $=($ date of access: 28.01.2020).

${ }^{41}$ Мочульська M.Є. Правова доктрина та правова наука: співвідношення понять. Проблеми державотворення і захисту прав людини в Україні : матеріали XVIII регіон. наук.-практ. конф. (м. Львів, 26-27 січ. 2012 р.). Львів : Нац. ун-т ім. І. Франка, 2012. C. 39. 
The first is a legal phenomenon objectified in the form of scientific legal theory developed by scientists to improve positive law; the second (specific) is a traditional and factual source of law, a system of scientific theories, views, concepts, recognized as binding on the scientific legal community and legal practice by sanctioning them by the judiciary and affecting law-making, law-interpreting and law-enforcement processes ${ }^{42}$. The provision that, in a narrow sense, legal doctrine should mean a separate subtype, a particular legal phenomenon that exists in a transitional society is equally important ${ }^{43}$.

There is a reasonable opinion given by I. V. Semenikhin that the doctrinal provisions become generally binding regulations of law, and that the legal doctrine acquires features of a formal source of law only in the case of sanction thereof ${ }^{44}$. With regards thereto, S. S. Aleksieiev hereby emphasizes that the addition of the provisions of the law by the courts results in the fact that in the sphere of law, together with the law, a special regulatory reality appears ${ }^{45}$. The source of this reality, from the point of view of O. O. Zozulia, is the legal doctrine, the most important, basic provisions and conclusions of which do not allow a judge to formulate rules that contradict the essence of law. Under certain circumstances (incomprehensibility, inaccuracy, framework law), the doctrine becomes a real source of law with judicial legitimation ${ }^{46}$.

According to M. M. Voplenko ${ }^{47}$ and V. P. Reutov ${ }^{48}$, the essence of such sanction is in the fact that the state, in the person of its supervisory and regulatory authorities does not deny, but admits with tacit consent or in the most general form recognizes and takes under its own protection of certain rules and regulations.

42 Мочульська М.Є. Правова доктрина в континентальній правовій системі : автореф. дис. ... канд. юрид. наук. Львів, 2011. С. 3-4, 9.

43 Мочульська М.Є. Правова доктрина в континентальній правовій системі : автореф. дис. ... канд. юрид. наук. Львів, 2011. С. 4.

44 Семеніхін І.В. Правова доктрина: загальнотеоретичний аналіз / за ред. О.В. Петришина. Харків : Юрайт, 2012. Вип. 2. С. 55.

45 Алексеев С. С. Право на пороге нового тысячелетия. Некоторые тенденции мирового правового развития - надежда и драма современной эпохи : монография. Москва : Статут, 2000. С. 120.

46 Зозуля А.А. Доктрина в современном праве : дис. ... канд. юрид. наук. СанктПетербург, 2006. С. 171.

${ }^{47}$ Вопленко Н.Н. Источники и формы права : учеб. пособие. Волгоград : Изд-во ВолГУ, 2004. 102 с.

48 Реутов В.П. Типы правопонимания и проблема источников и форм права. Вестник Пермского университета. 2010. № 2 (8). С. 60. 
S. S. Aleksieiev, P. P. Baranov, S. V. Baturin otherwise perceives the legal doctrine, namely as a category of much higher order. In their understanding, it is a complex, integrating category, acting as a kind of model of political and legal reality, legal regulation, reflects the needs of the society, its spiritual and moral foundations, culture, traditions of law and state formation. I. V. Semenikhin also states that the doctrine traditionally related to the position of leading authoritative lawyers, in this sense, serves as a system-forming element, theoretical and methodological foundation of the legal system, state policy in the field of legal regulation, reflects and defines the general model of the latter ${ }^{49}$.

It should be noted that, according to the provisions provided for by the modern procedural laws, "parties to the case are entitled to sue the expert in the field of law regarding the content of the rules of foreign law in accordance with their official or generally accepted interpretation, practice of application, doctrine in the respective foreign state" (para. 2 of Part 1 of Article 112 of the Cassation Arbitration Court of Ukraine) ${ }^{50}$. Identical provisions are contained in the provisions of para. 2 of Part 1 of Article 114 of the Civil Procedure Code of Ukraine ${ }^{51}$, as well as in para. 2 Para 1 of Article 108 of the Commercial Court of Ukraine ${ }^{52}$.

The possibility of the court applying the legal doctrine provided for by the laws of Switzerland, in Article 1 of the Civil Code which the legislator has established the duty of the court to observe the legal doctrine in the administration of justice. Courts of other continental states, including Ukraine, actively use the findings of scientific legal expertise, doctrinal methods of judicial expertise, and comment on regulatory legal acts.

The doctrine is a complex multifaceted legal phenomenon and has a broad functional purpose ${ }^{53}$. Therefore I. S. Zelenkevich attributes it to the

49 Семеніхін І.В. Правова доктрина: загальнотеоретичний аналіз / за ред. О.В. Петришина. Харків : Юрайт, 2012. Вип. 2. С. 18.

${ }^{50}$ Кодекс адміністративного судочинства України : Закон України від 06.07.2005 № 2747-IV. URL: http://zakon2.rada.gov.ua/laws/card/2747-15 (date of access: 27.01.2020).

51 Цивільний процесуальний кодекс України : Закон України від 18.03.2004 № 1618-IV. URL: https://zakon.rada.gov.ua/laws/show/1618-15 (date of access: 27.01.2020).

52 Господарський процесуальний кодекс України : Закон України від 06.11.1991 № 1798-XII. URL: https://zakon.rada.gov.ua/laws/show/1798-12 (date of access: 27.01.2020).

53 Люлькович С.Н. Определение и свойства доктрины (науки) как источника права. Правовая система Республики Беларусь: состояние, проблемы и перспективы развития : материалы IX межвуз. науч. конф. студентов, магистров и аспирантов 
most ancient and mysterious sources of law ${ }^{54}$ From the point of view of S. V. Boshno, it is referred to those legal phenomena which not only repeatedly changed and continue to change the status thereof, but also seek, so to speak, to dissolve in science, jurisprudence, religion, general principles and other forms and sources of law, different phenomena of state-legal reality ${ }^{55}$. Yu. S. Gambarov, who uses the term "law of lawyers" by referring the relevant legal phenomenon paid attention to the aforesaid characteristic feature of legal doctrine, which in his understanding is a symbiosis of legal theory (science) and jurisprudence ${ }^{56}$. In view of this, L. O. Korchevna's approach, which reduces the complex phenomenon of legal doctrine to regulations and principles, should be considered unreasonably narrowed ${ }^{57}$.

Continuing our consideration of the issue, we will point out that the formation of environmental law doctrine in the context of the present requires a prudent approach and a rethinking of the highest social values that are vital, such as: a) human rights (including natural, fundamental, environmental priorities); b) the safety of society as a whole and its component - environmental safety; c) sovereignty of the state (not only as the rule, independence, completeness and indivisibility of power within the territory of the state, independence and equality in external relations, but also as protection of human rights, freedoms and its interests); d) the rule of law, etc.

In addition to the above, it should be remembered that the environmental law doctrine originates from the doctrine of the Soviet era and is related to the doctrine of natural resource, environmental law. By the way, the formation of the Soviet doctrine is related to the names of well-known environmental lawyers, such as: Yu. O. Vovk, O. S. Kolbasov, V. L. Muntian, V. V. Petrov, B. G. Rozovskyi, N. I. Titova et al. In

(г. Гродно, 9 апр. 2009 г.). Гродно : ГрГУ, 2009. С. 196; Романова Е.В. Судебная доктрина в системе источников налогового права США : автореф. дис. ... канд. юрид. наук. Москва, 2012. С. 13; Мадаев Е.О. Доктрина в правовой системе Российской Федерации : дис. ... канд. юрид. наук. Иркутск, 2012. С. 24.

54 Зеленкевич И. С. Правовая доктрина и правовая наука: некоторые аспекты соотношения и использования в качестве источников права. СевероВосточный научный журнал. 2010. № 2 (6). С. 42.

55 Бошно С.В. Доктрина как форма и источник права. Журнал российского права. 2003. № 12. С. 70.

${ }^{56}$ Гамбаров Ю.С. Гражданское право. Общая часть : лекции, прочитан. в Моск. ун-те. Москва : Литогр. Общ. распр. п. кн., 1898. 439-440.

57 Корчевна Л.О. Проблема різноджерельного права: досвід порівняльного правознавства : дис. ... д-ра юрид. наук. Київ, 2005. 412. С. 75-83. 
particular, V. I. Andreitsev believes that the scientific doctrines of environmental law in historical and chronological order can be divided into two varieties: a) scientific doctrines of environmental law of the Soviet era; b) scientific doctrines of the era of independent Ukraine ${ }^{58}$.

It is also worth paying attention to the classification of available doctrinal environmental legal achievements of legal scholars proposed by O. O. Orendarets. Therefore, according to the scientist, we can distinguish the following historical and legal stages of development of science of environmental law: the first is the beginning of the 60's of the twentieth century, distinguished by the emergence of studies of general theoretical problems of land and collective farm law, on the basis of which in the future began to develop the science of environmental law; the second 60 years - the end of the 70's of the twentieth century. It is marked by further scientific researches of the legal protection of the environment and the development of laws on nature protection; the third -80 years - the beginning of the 90's of the 20th century - is a turning point, when new doctrinal approaches to the evolution of environmental law in Ukraine emerge, formation and active development of the doctrine as a holistic complex system of scientific knowledge, and characterized by the expansion of the subject and objects of science of environmental law, the deepening of general theoretical developments and origins substantiation of many environmental concepts; fourth - the end of the 90's of the $20^{\text {th }}$ century and up to this day - it is considered a stage of intensive development of new directions of this science on a qualitatively new basis in the conditions of an independent Ukrainian state, it is marked by a significant expansion of the system of science of environmental law, its subject and objects, which contributes to the emergence of new legal institutions, conceptual scientific developments, etc ${ }^{59}$. As O. O. Orendarets points out, the classification that she proposed is conditional by virtue of the fact it is impossible to determine with the utmost accuracy the moment of the beginning of environmental legal research, and it cannot be clearly stated either when the science of environmental law emerged. The aforementioned classification is based on several criteria: legal, historical, political and subjective. However, the author does not specify which

58 Андрейцев B.I. Наукова доктрина - методологія пізнання та удосконалення екологічного права та практики його застосування. Сучасні науково-практичні проблеми екологічного, земельного та аграрного права : матеріали круглого столу (м. Харків, 6 груд. 2013 р.) / за заг. ред. А.П. Гетьмана. Харків : Право, 2013. С. 12.

59 Орендарець О.О. Розвиток науки екологічного права : автореф. дис. ... канд. юрид. наук. Київ, 2015. С. 10-11. 
scientific studies fall into the doctrinal category. In our opinion, differentiating the latter by four criteria is not quite the right step. At the same time, you can agree with the outlined point of view to some extent.

If we talk about the birth of environmental law doctrine, it would be desirable to distinguish the signs of doctrinal science, their impact on the formation of environmental laws, strategies for the development of state environmental policy, scientific reasonableness (validity) and formal and logical compliance with recognized legal principles. and the regularities of legal science with the possibility of its further legitimation in environmental consciousness, as well as the official recognition by the state as a trend of modern state environmental policy, enshrined in the Law of Ukraine "On the Fundamental Principles (Strategy) of the State Environmental Policy of Ukraine for the Period until 2030" dated February 28, 2019 No. 2697 VIII, the initial position of the Institute of ownership of natural resources related to natural law doctrine, as well as the perception of recent legal practice.

In summary, we can state that the environmental law doctrine should be regarded as a sector legal, that is, as a type of concept in relation to legal doctrine. Given that the purpose of this study was not to classify legal doctrines, but to shed light on some points, it is required to ascertain the relationship between environmental law doctrine. We differentiate the latter into: a) the general doctrine of law; b) the legal doctrine of a particular branch of law, namely environmental law, civil law, etc.; c) the legal doctrine of a separate law institute (sector, inter-branch), including ownership of natural resources.

It should be noted again that the formation of environmental law doctrine is significantly influenced by the European integration processes. According to V. Ya. Tatsiy, there is an urgent need for scientific development of a system of general doctrinal views as a legal ideological basis for the activity of the legislative and executive branches of government in the implementation of the Strategy of integration of Ukraine with the European Union $^{60}$. In turn, A. P. Hetman believes that the goal of legal integration is to unify national legal systems into a single geo-legal space. This process is complex, consisting of several stages, covering: a) deepened interaction and harmonization of principles of formation of the international legal system; b) approximation of national

60 Тацій В.Я. Правова наука та іï завдання щодо забезпечення розвитку громадянського суспільства в Україні. Вибрані статті, виступи, інтерв'ю / упоряд.: О.В. Петришин, Ю.Г. Барабаш, В.І. Борисов. Харків : Право, 2010. С. 539. 
legal systems to international ones, provided that national laws is previously adapted to the legal standards of that system; c) entry of national legal systems into international law and their final adaptation within the single legal space ${ }^{61}$. At the same time, O. D. Tykhomyrov points out that legal space as a concept of legal science has not yet become generally accepted, its interpretation depends on different approaches to legal thinking, philosophical and legal concepts, national legal doctrine, scientific positions of scientists and other factors. Legal space is interpreted as: 1) a way of daily perception of the legal world; 2 ) the concept of legal science, reflecting the diversity of legal phenomena, their relative location and connection or lack thereof; 3 ) together with legal time is an attributive form of existence of legal matter. In modern legal science, legal space is regarded as both an independent legal phenomenon and as a property, a form of existence of other legal phenomena, in particular in the context of the understanding of legal matter, freedom of subjects of law, legal reality, subject of legal regulation, territory of the state or non-state territories and their boundaries, legal acts, legal communication, etc. The scientist believes that due to the "revival" of the spatial approach, such concepts as "social space", "economic space", "environmental space", "and information space" and others have emerged.

Therefore, legal space is of methodological importance in one aspect or another, in one form or another, for any legal research, and not just scientific, of course, recognizing that space is one of the main forms of being of matter ${ }^{62}$. It should be agreed that in the current environment

${ }^{61}$ Гетьман А.П. Сучасний стан та перспективи розвитку еколого-правової науки в Україні. Екологічне право в системі міждисциплінарних зв'язків: методологічні засади : матеріали круглого столу (м. Харків, 4 груд. 2015 р.). Харків : Право, 2015. C. 16.

${ }^{62}$ See: Гнатовський М.M. Європейський правовий простір: Концепція та сучасні проблеми. Київ : Вид. дім “Промені”, 2005. 222 с.; Гнатовський М.М. Становлення та тенденції розвитку європейського правового простору : автореф. дис. ... канд. юрид. наук. Київ, 2002. 22 с.; Гнатовський М.М. Становлення та тенденції розвитку європейського правового простору : дис. ... канд. юрид. наук. Київ, 2002. 193 с.; Кравчук В.М. Філософська площина осягнення правового простору. Актуальні проблеми держави і права. 2011. Вип. 58. С. 63-69; Перчеклій І.М. Право власності українського народу на природні ресурси: еколого-правові засади : автореф. дис. ... канд. юрид. наук. Київ, 2015. 16 с.; Петражицкий Л.И. Введение в изучение права и нравственности. Основы эмоциональной психологии. Санкт-Петербург : Тип. Ю.Н. Эрлих, 1908. 271 с.; Петражицкий Л. И. Теория права и государства в связи с теорией нравственности : в 2 т. Санкт-Петербург : Слово, 1907. Т. 1. 656 с.; 
environmental law space are subject to legal regulation, legal acts and can now become the object of study of environmental law doctrine.

\section{The impact of environmental law doctrine on the state environmental policy formation and the environmental legislation systematization}

In addition to the above, it should be noted that the state environmental policy is a category: a) "dynamic" related to innovative development; b) aimed at satisfying public and private interests; c) functionally linked to other priority areas of public policy; d) implies a plurality of species of subject-object composition; e) it is based on the competitive basis of the use of natural resource potential; f) requires effective economic and legal measures to take advantage of natural resource potential; g) has a longterm character; $h$ ) promotes the modernization of the system of measures for the protection and reproduction of natural resources; i) ensure the improvement of the legal system for environmental policy; j) should aim at achieving international environmental quality standards, etc.

In today's context, state environmental policy should be developed on the basis that the main landmarks of the right to use natural resources should be the conservation of biological and landscape diversity, restoration of environmentally polluted territories, protection and reproduction of natural resources, compliance with environmental security requirements of the population and territories. In view of the above, we give the definition of "state environmental policy" (as a component of state policy) - a system of legal, organizational, economic, social, ideological and other measures of the state, which are taken to preserve nature safe for nature, protection of life and health population, the achievement of harmonious interaction between society and nature, protection, rational use and reproduction of natural resources. However, this is only one side of the problem, because in the formulation of national environmental policy, one should not forget that nowadays national laws, among other things, should be brought into line with EU requirements, and the conclusions set out in the analytical note "Analysis of the Experience of European Cooperation as for the Formation and Implementation of Environmental Policy

\footnotetext{
Тихомиров Д.О. Простір правовий. Велика українська юридична енциклопедія : у 20 т. Т. 2 : Філософія права / редкол.: С.І. Максимов (голова) ; Нац. акад. прав. наук України ; Ін-т держави і права ім. В.М. Корецького НАН України ; Нац. юрид. ун-т ім. Ярослава Мудрого. Харків : Право, 2017. С. 703-707.
} 
Institutions and Instruments" should become the guiding provisions. Therefore, according to this document, the principles of EU environmental policy recognized: 1 ) the principle of subsidiarity (joint action in those areas in which an individual country cannot cope alone, or more coordinated solution of the problem in more than one state); 2) the principle of preventive (preventive) actions; 3 ) the precautionary principle; 4) the principle of compensation for damage to the environment by eliminating the damage at the initial stage of its occurrence; 5) the principle of environmental orientation, when any activity is carried out taking into account the needs of the environment; 6) the polluter pays principle, the effectiveness of which was substantially strengthened in 2004 by Directive 2004/35/EC on civil liability for environmental pollution; 7) the principle of integrating environmental policy into the design and implementation of all other policies $^{63}$.

Furthermore, as it is also stated in the note, due to the trends of the last decades and due to the need to improve and update the environmental policy, the list of environmental protection measures has been expanded. In addition to the adoption of framework laws to ensure a high level of environmental protection, the EU has introduced a number of new instruments (some used in Ukraine): a) LIFE is a financial instrument for environmental protection, its introduction contributes to the development, implementation and updating of environmental policy and laws of the EU; b) environmental agreements, which include obligations to comply with the environmental aspects of the operations of enterprises and the use of methods to encourage the voluntary implementation of environmental measures; c) environmental duties and taxes, that is, the application by Member States of fiscal instruments to improve the effectiveness of environmental policies and ensure their compliance with EU law; d) support programs for NGOs active in the field of environmental protection; e) integrated product policy: The Commission presents a strategy to strengthen and change the focus of production-related environmental policies to promote the market for environmentally friendly products and, ultimately, to stimulate public debate on specific issues; f) the European Environment Agency (through which political resolutionmakers and the public are able to obtain reliable and reliable

63 Аналіз досвіду Європейського співробітництва щодо формування і втілення інституцій та інструментів екологічної політики : аналіт. зап. URL: http://www.niss.gov.ua/articles/840/ (date of access: 28.01.2020). 
environmental information); g) eco-labeling of products (aims at promoting products with reduced environmental impact, compared to other products in the same group); h) the EMAS Environmental Management and Environmental Audit System (EMAS), which is used to improve and improve the environmental performance of European organizations, as well as to provide relevant information to the public and stakeholders; i) environmental impact assessment (EIA) of certain public and private projects; $\mathrm{j}$ ) assessing the environmental impact of the implementation of plans and programs to promote the integration of environmental aspects at the stages of their development and adoption; k) environmental audits by minimum criteria, thereby achieving greater compliance as well as uniformity in the application and implementation of EU environmental laws by providing minimum criteria for the organization, post-control and publication of the results of environmental audits in all Member States; 1) The European Pollutant Release and Transfer Registry (PRTR), which maintains public access to environmental information, which, in turn, prevents or reduces pollution in the long term ${ }^{64}$.

However, the establishment of the essence, content and purpose of environmental law doctrine depends on an understanding of its nature. The idea of filling the concept of "environmental law doctrine" comes by exploring certain approaches to its interpretation. The first is related to the category of "influence", that is, consideration of the relevant systemic influence of natural law doctrine and other ideological factors on environmental consciousness, culture, and way of social life for the formation of stable and deep knowledge, modern legal development of environmental relations.

From the point of view of the second approach, the definition of the concept under study ("environmental law doctrine") is connected and can be considered through the category "function" as a consistent, systematic, directed activity of the state and its organs, public associations, organizations, scientists, aimed at formation of a certain system of environmental knowledge, consciousness, legal understanding of the doctrines, environmental-legal science and state environmental policy. According to O. O. Zozulia, the current state of the legal system requires a fuller use of the law-making potential of the legal doctrine and the

${ }^{64}$ Аналіз досвіду Європейського співробітництва щодо формування і втілення інституцій та інструментів екологічної політики : аналіт. зап. URL: http://www.niss.gov.ua/articles/840/ (date of access: 28.01.2020). 
realization of its basic functions - stabilizing, guiding, heuristic, regulatory, evaluative and predictive ${ }^{65}$.

The proponents of the third approach believe that the environmental law doctrine is formed under the influence of natural law doctrine as a methodological platform and is regarded as a process of positing the provisions of natural law in environmental laws. Like any process, it is characterized by certain content, due to historical, economic, social, ideological, political and environmental factors, has certain components: information, evaluation (formation of values), regulatory, legitimation (necessity of regulations), and organizational ones. In the fourth, the conceptual provisions provided for by the environmental law doctrine is implemented by incorporating the doctrinal provisions into the text of regulatory legal acts or direct reference thereto by taking into account during their adoption by law enforcement authorities, as well as the actual effect of legal doctrine as a form of law.

Based on the concepts of the fifth approach, the adoption of regulatory acts is related to the need to consolidate the principles of environmental law doctrinal provisions of state environmental policy. Therefore, the environmental law doctrine is recognized, i.e. it is due to the reflection of its provisions in the programming documents political, economic and other orientation, regulatory and legal acts, contractual and customary regulations, to resolutions adopted by the public authorities.

\section{CONCLUSIONS}

In view of this, it can be stated that the national environmental law doctrine is a kind of sector legal doctrine, its system-forming element, theoretical and methodological foundation of the legal system, source (form) of environmental law; its basis is the provision of universal scholars of environmentalists who have scientific value and are recognized by the legal community, which serves as the basis for legitimizing the doctrine in the public consciousness, possible official recognition by the state. In addition to the above, based on it, strategic directions of state environmental policy are set, prospects for further development of environmental laws, conceptual approaches to solving environmental problems are introduced and scientifically substantiated, and most importantly, it can be a regulator of public environmental relations. Considering all this, we should add that the main function of the

65 Зозуля А.А. Доктрина в современном праве : дис. ... канд. юрид. наук. СанктПетербург, 2006. С. 11. 
environmental law doctrine should be to promote the creation of a basis for law-making and enforcement. In other words, reflecting the dominant views in the society of representatives of environmental law schools on environmental law, its value and role in the life of the society, environmental law doctrine is a kind of basis for the development of environmental legal regulations, justifies the need and expediency of fixing the law, is an important factor in accelerating the process of becoming law. It has such features as science, consistency, efficiency and stability, etc.

The environmental law doctrine should promote: a) its use in the law-making process, in the development of legal acts and their adaptation to European standards; b) formulation of legislative definitions that will gradually be transformed into an important part of environmental regulations; c) development of the Concept of development of environmental law and laws; d) further codification of environmental laws; e) development of state environmental policy, etc. In the current context of the process of reforming environmental laws, it is advisable to talk about the establishment in the courts of a mechanism for authorizing environmental law doctrine by adopting judgments under the provisions thereof. Natural law doctrine is a significant factor in the ordering of environmental law doctrine, environmental relations, as it is a dynamic category, able to take into account environmental public interests and balance them with the private, and the needs of the society - with the personal environmental needs and rights of citizens.

In view of the foregoing, as well as civilization challenges, Ukraine first needs to activate law-making, modernize environmental law doctrine, relying on concepts which will be revised, relevant provisions of science, state policy, legal understanding and, consequently, law enforcement. It is required to institutionalize the components of environmental law doctrine in the system of environmental laws, which becomes a decisive condition for the further development of statehood and optimization of the rule-making process. The latest philosophical and legal ideas that can positively influence the improvement of the environmental laws (legislative environmental process) should be the basis for that. The environmental law doctrine should become an effective means of harmonizing the system of environmental law and laws, contribute to the definition of the main directions of state environmental policy, and take into account the requirements of the world community and human values. 


\section{SUMMARY}

The influence of environmental law doctrine on the development of state environmental policy and legislation is analyzed in this article. Drawing on methodological approaches, the environmental law doctrine is considered as the branch legal basis of environmental law, state environmental policy, which is institutionalized in environmental legislation and is an integrating set of legal and scientific interpretations and views on law, within which legal forms of cognition of the law and legal phenomena, principles, concepts, terms and constructs are developed, methods, means, techniques of perception, understanding and interpretation of its sources, systems, structures, etc. are substantiated.

The purpose of this article is to consider and to streamline the theoretical and methodological background of the environmental law doctrine formation, to outline perspective directions of establishment and to determine the features of its application in national policy improving, in particular for the environmental legal relations reforming, and further systematization of environmental legislation in the context of European integration and sustainable development, as well as to represent our own vision of this issue.

It is proved that further systematization of environmental legislation should take place on the basis of elaboration of a single scientific doctrine, which will contribute to the correct interpretation of legal norms, overcoming contradictions, collisions and gaps in the current environmental legislation of Ukraine. At the same time, it is concluded that the key task of our country in the context of European integration is to create a coherent, logically agreed national environmental law doctrine as a theoretical basis of the rulemaking processes and to form a single legal space.

\section{REFERENCES}

1. Alekseev S. S. Law on the threshold of a new millennium. Some trends in global legal development - the hope and the drama of the modern era: a monograph. Moscow: Statute, 2000. 256 p.

2. An analysis of the experience of European cooperation in the formulation and implementation of environmental policy institutions and instruments: an analytical note. URL: http://www.niss.gov.ua/articles/840/ (date of access: 01/27/2020).

3. Andreytsev V. I. Environmental law and legislation of sovereign Ukraine: problems of implementation of state environmental policy: Monograph. Dnipro: National mining University, 2011. 373 p. 
4. Andreytsev V. I. Incorporation as an important form of systematization of environmental legislation. Legal Doctrine of Ukraine: Monograph: in 5 vols. Vol. 4: Doctrinal Problems of Environmental, Agrarian and Business Law / Yu. S. Shemshuchenko, A. P. Getman, V. I. Andreytsev, et al. ; for the total. ed. Yu. S. Shemshuchenko. Kharkiv: Pravo, 2013. Subsection 1.4. P. 169-192.

5. Andreytsev V. I. Scientific and scientific-practical schools: status and prospects of legal regulation: monograph. Kiev: Znannya, 2009. $414 \mathrm{p}$.

6. Andreytsev V. I. Scientific doctrine - a methodology of cognition and improvement of environmental law and practice of its application. Modern scientific and practical problems of environmental, land and agrarian law: materials of the round table (Kharkiv, Dec 6, 2013) / for the total. ed. A. P. Getman. Kharkiv: Pravo, 2013. P. 11-14.

7. Anisimova H. V. The influence of the natural-law concept on the development of environmental law doctrine, science and legislation. The level of efficiency and necessity of influence of legal science on rulemaking activity and legal practice: materials of international of scientific-practical conference (Kharkiv, February 5-6, 2016). Kharkiv, 2016. P. 52-55.

8. Baliuk G. I. The role of the environmental law doctrine in the initiation and development of nuclear legal research in Ukraine. Legal Doctrine of Ukraine: Monograph: in 5 vols. Vol. 4: Doctrinal Problems of Environmental, Agrarian and Business Law / Yu. S. Shemshuchenko, A. P. Getman, V. I. Andreytsev, et al. ; for the total. ed. Yu. S. Shemshuchenko. Kharkiv: Pravo, 2013. Subsection 1.7. P. 252-268.

9. Boshno S. V. The Doctrine as a Form and Source of Law. Journal of Russian Law. 2003. № 12. P. 70-79.

10. Gambarov Yu. S. Civil law. General part: lectures, read in Moscow. university. Moscow: Book Distribution Lithographic Society, 1898.766 p.

11. Getman A. P. Current state and prospects of development of environmental-legal science in Ukraine. Environmental law in the system of interdisciplinary communication: methodological foundations: round table materials (Kharkiv, December 4, 2015). Kharkiv: Pravo, 2015. P. 15-27.

12. Getman A. P. Doctrine of Environmental Law and Legislation of Ukraine: Monograph. Kharkiv: "Oberig” LLC, 2019. 336 p. (Kharkiv Scientific School of Environmental Law).

13. Hnatovsky M. M. European legal space: Concept and contemporary problems. Kyiv: Publishing House "Promeni", 2005. 222 p. 
14. Hnatovsky M. M. Formation and tendencies of development of the European legal space: diss. abstract ... cand. of legal sciences. Kyiv, 2002. 22 p.

15. Hnatovsky M. M. Formation and tendencies of development of the European legal space: diss. ... cand. of legal sciences. Kyiv, 2002. 193 p.

16. International Police Encyclopedia: 10 Vol. ed. Yu. I. Rimarenko, Ya. Yu. Kondratiev, V. Ya. Tatsiy, Yu. S. Shemshuchenko. Volume 1: Theoretical and methodological and conceptual principles of police law and police deontology. Kyiv: In Yure, 2003. 1232 p.

17. Karmalita M. V. Legal doctrine - source (form) of law: diss. abstract ... cand. of legal sciences. Kyiv, 2011.21 p.

18. Khabrieva T. Ya. Doctrinal significance of the Russian Constitution. Journal of Russian Law. 2009. No. 2. P. 34-38.

19. Korchevna L. O. The Problem of Multisource Law: The Experience of Comparative Law: Dis. ... Dr. of legal sciences. Kyiv, 2005. 412 p.

20. Korkunov N. M. Lectures on the general theory of law. Ed. 4. St. Petersburg: Ed. legal books shop of N. K. Martynov, 1897. 354 p. URL: http://library.nlu.edu.ua/cgi-bin/irbis64r_01/cgiirbis_64.exe?Z21ID= $\& I 21 \mathrm{DBN}=\mathrm{IBIS} \& \mathrm{P} 21 \mathrm{DBN}=\mathrm{IBIS} \& \mathrm{~S} 21 \mathrm{STN}=1 \& \mathrm{~S} 21 \mathrm{REF}=3 \& \mathrm{~S} 21 \mathrm{FMT}=\mathrm{fu}$ llwebr $\& C 21 \mathrm{COM}=\mathrm{S} \& S 21 \mathrm{CNR}=20 \& S 21 \mathrm{CNR}=20 \& \mathrm{~S} 21 \mathrm{STR}=\quad$ (date of access: 01/27/2020).

21. Kravchuk V. M. Philosophical plane of comprehension of legal space. Actual problems of the state and law. 2011. Iss. 58. P. 63-69.

22.Legal Doctrine of Ukraine: Monograph: 5 volumes. V. 1: General Theoretical and Historical Jurisprudence / V. Ya. Tatsiy, O. D. Svyatotsky, S. I. Maximov, et al.; for the total. ed. O. V. Petryshyn. Kharkiv: Pravo, 2013. 976 p.

23.Legal Doctrine of Ukraine: monograph: in 5 volumes. Vol. 4: Doctrinal problems of environmental, agrarian and commercial law / Yu. S. Shemshuchenko, A. P. Getman, V. I. Andreytsev et al.; for the total. ed. Yu. S. Shemshuchenko. Kharkiv: Pravo, 2013. 848 p.

24. Lyubitenko D. Yu. System features of legal doctrines. Bulletin of the Vladimirskiy Law Institute. 2011. № 1. P. 140-145.

25. Lyulkovich S. N. Definition and features of doctrine (science) as a source of law. The legal system of the Republic of Belarus: state, problems and development prospects: materials of the IX inter-university. scientific conf. of students, masters and graduate students (Grodno, April 9, 2009). Grodno: GrSU, 2009. P. 195-197.

26. Madaev E. O. Doctrine in the legal system of the Russian Federation: dis. ... cand. of legal sciences. Irkutsk, 2012. 254 p. 
27. Maximov S. I. Legal doctrine: philosophical and legal approach. Legal Doctrine of Ukraine: monograph: 5 volumes / ed. V. Ya. Tatsiy, O. D. Svyatotsky, S. I. Maximov [and others]. Volume 1: General Theoretical and Historical Jurisprudence / by general ed. O. V. Petryshyn. Kharkiv: Pravo, 2013. Subsection 1.3. P. 58-93.

28. Mochulska M. E. Legal doctrine and legal science: the relation of concepts. Problems of state formation and protection of human rights in Ukraine: materials XVIII. of scientific-practical conf. (Lviv, January 26-27, 2012). Lviv: I. Franko National university, 2012. P. 39-41.

29. Mochulska M. E. Legal doctrine in the continental legal system: diss. abstract ... cand. of legal sciences. Lviv, 2011. 19 p.

30. On Basic Principles (Strategy) of the State Environmental Policy of Ukraine for the period up to 2030 : Law of Ukraine dated 28.02.2019 № 2697-VIII. URL: https://zakon.rada.gov.ua/laws/show/2697-19 (date of access: 27.01.2020).

31.On Environmental Protection : Law of Ukraine dated 25.06.1991 № 1264-XII. URL: http://zakon5.rada.gov.ua/laws/show/1264-12 (date of access: 27.01.2020).

32. On Higher Education : Law of Ukraine dated 01.07.2014 № 1556-VII. URL: https:// zakon.rada.gov.ua/laws/show/1556-18 (date of access: 27.01.2020).

33. Onishchenko N. M. The legal system: problems of theory: a monograph. Kyiv: V. M. Koretsky Institute of state and law of National Academy of Sciences of Ukraine, 2002. 352 p.

34.On Scientific and Technical Operations : Law of Ukraine dated 26.11.2015 № 848 VIII. URL: http://zakon5.rada.gov.ua/laws/show/848-19 (date of access: 27.01.2020).

35. On the National Research Fund of Ukraine : the Resolution of the Cabinet of Ministers of Ukraine dated 04.07.2018 № 528. URL: http://zakon.rada.gov.ua/laws/show/ru/528-2018-\%D0\%BF (date of access: 27.01.2020).

36. On the Strategy for Sustainable Development "Ukraine-2020" : approved by the Decree of the President of Ukraine dated 12.01.2015 № 5/2015. URL: http://zakon2.rada.gov.ua/ laws/show/5/2015 (date of access: 27.01.2020).

37. Orendarets O. O. Development of the science of environmental law: diss. abstract ... cand. of legal sciences. Kyiv, 2015. 16 p.

38. Parkhomenko N. M. Sources of law: problems of theory and methodology: monograph. Kyiv: Yurid. dumka, 2008. 336 p. 
39. Parkhomenko N. M. System of sources of law: features, properties and content. Journal of the Kyiv University of Law. 2007. № 3. P. 8-12.

40. Perchekliy I. M. The right of property of the Ukrainian people to natural resources: environmental and legal bases: diss. abstract ... cand. of legal sciences. Kyiv, 2015. 16 p.

41. Petrazhitskiy L. I. Introduction to the study of law and morality. Fundamentals of emotional psychology. St. Petersburg: Typ. Yu. N. Erlich, 1908. $271 \mathrm{p}$.

42. Petrazhitskiy L. I. The theory of law and the state in connection with the theory of morality: in 2 volumes. St. Petersburg: Slovo, 1907. T. $1.656 \mathrm{p}$.

43. Puzikov R. V. Legal doctrine in the field of legal regulation (problems of theory and practice): dis. ... cand. of legal sciences. Tambov, 2003.221 p.

44. Reutov V. P. Types of legal understanding and the problem of sources and forms of law. Bulletin of Perm University. 2010. No2 (8). P. 54-70.

45. Romanova E. V. Judicial doctrine in the system of sources of tax law in the USA: diss. abstract ... cand. of legal sciences. Moscow, 2012. $23 \mathrm{p}$.

46. Semenikhin I. V. Legal Doctrine: General Theoretical Analysis / ed. O. V. Petryshyn. Kharkiv: Yurayt, 2012. Vol. 2. 88 p.

47. Skakun O. F. Theory of state and law: a textbook. Kharkiv: Konsum, 2000.704 p.

48. Sorokin V. V. Judicial practice or legal doctrine. Arbitration and civil proceedings. 2002. No. 8. P. 8-11.

49. Tatsiy V. Ya. Legal science and its tasks for ensuring the development of civil society in Ukraine. Selected articles, speeches, interviews / ed. : O. V. Petryshyn, Yu. G. Barabash, V. I. Borisov. Kharkiv: Pravo, 2010. 936 p.

50. The Civil Procedural Code of Ukraine : Law of Ukraine dated 18.03.2004 № 1618-IV. URL: https://zakon.rada.gov.ua/laws/show/161815 (date of access: 27.01.2020).

51. The Code of Administrative Proceedings of Ukraine : Law of Ukraine dated 06.07.2005 № 2747-IV. URL: http://zakon2.rada.gov.ua/ laws/card/2747-15 (date of access: 27.01.2020).

52. The Commercial and Procedural Code of Ukraine : Law of Ukraine dated 06.11.1991 № 1798-XII. URL: https://zakon.rada.gov.ua/laws/ show/1798-12 (date of access: 27.01.2020). 
53. The Great Ukrainian Legal Encyclopedia: in 20 vols. Vol. 3: General Theory of Law / ed.: O. O. Petryshyn (Chairman) [and others]; National Academy of Legal Sciences of Ukraine; V. M. Koretsky Institute of state and law of National Academy of Sciences of Ukraine; Yaroslav Mudryi National Law University. Kharkiv: Pravo, 2017. 952.

54. Theory of state and law: a textbook / O. V. Petryshyn, S. P. Pogrebnyak, V. S. Smorodinsky [and others]; ed. O. V. Petryshyn. Kharkiv: Pravo, 2014. 368 p.

55. Tikhomirov D. O. Legal space. The Great Ukrainian Legal Encyclopedia: in 20 vols. Vol. 2: Philosophy of Law / ed : S. I. Maximov (Chairman); National Academy of Legal Sciences of Ukraine; V. M. Koretsky Institute of state and law of National Academy of Sciences of Ukraine; Yaroslav Mudryi National Law University. Kharkiv: Pravo, 2017. P. 703-707.

56. Trofimenko V. A. In search of an ideal source of law: legal doctrines of the world. Legal advisor. 2007. № 4 (18). P. 82-88.

57. Voplenko N. N. Sources and forms of law: tutorial. Volgograd: VolGU Publishing House, 2004. 102 p.

58.Zelenkevich I. S. Legal doctrine and legal science: some aspects of correlation and usage as sources of law. Northeast Science Journal. 2010. № 2 (6). P. 42-47.

59.Zozulya A. A. The Doctrine in Modern Law: diss. abstract ... cand. of legal sciences. St. Petersburg: St. Petersburg Humanitarian University of Trade Unions, 2006. $31 \mathrm{p}$.

60.Zozulya A. A. The Doctrine in Modern Law: diss. ... cand. of legal sciences. St. Petersburg, 2006. 232 p.

\section{Information about the author: Anisimova H. V., $\mathrm{PhD}$ of Legal Sciences,} Associate Professor at the Environmental Law Department, Yaroslav Mudryi National Law University 


\section{AN OVERVIEW OF THE METHODOLOGICAL APPROACHES TO RESEARCH OF ENVIRONMENTAL LAW AND LEGISLATION}

\section{Sydor V. D., Kostytska I. O.}

\section{INTRODUCTION}

The dynamics of the development of the environmental relations of the society confronts the science of environmental law with many problems. The destruction of the economic and socio-political system of the Soviet society led to a certain disruption in the research of the methodology of social processes. Rapid reforms of the economic and political system of Ukraine, significant dynamic formation of the new forms of social life require appropriate legal provision that would be based on the modern scientific theory and methodology.

The analysis of the scientific literature reveals the different, often contradictory approaches to the interpretation of both the concept and the essence of the methodology and it characteristics, features and developmental trends in the science of environmental law. It can be explained by the diversity of methodological investigations that differ by their theoretical level, the degree of differentiation of their own methodological problems from the object of its study, and by the author's understanding of the basic methodological research methods and techniques of environmental-legal phenomena.

There is a general opinion in legal literature that the methodology of science should be considered as the study of general principles, ways, patterns of scientific knowledge, principles and practices that are carried out at different levels (philosophical, scientific, specific sciences, methods and techniques). They aim at development of the provisions that give the opportunity to choose tools and to build procedures which will effectively resolve problems and challenges that arise in the process of research. The methodology defines the means of gaining scientific knowledge, which reflects the dynamic processes and phenomena, provides comprehensiveness of information, creates a system of legal information that is based on objective facts. 


\section{Classical Methods and Approaches of Ecological Legal Research}

Environmental methodology contains knowledge about:

1) approaches, principles, methods and techniques which are to be used in studying the sources of law;

2) approaches, principles, methods and techniques of knowledge which should be used in any experimental procedure;

3 ) the content of specific approaches, principles, methods and techniques used for the law sources and the consequences of their development;

4) the way the methods are interrelated in the process of learning and obtaining new knowledge.

The methodology of the legal science is a system of approaches, methods and techniques of the scientific research, the theoretical basis of their usage in the study of the state-legal phenomena.

The basis of the methodology of legal science is presented by such approaches:

1) philosophical and ideological approaches (materialistic or idealistic, metaphysical or dialectical, recognition or denial of the objective social, including state-legal, patterns and possibilities of their studying and gaining true knowledge about them);

2) general scientific methods, that are used in all or most sciences (structural, functional methods, method of transition from the abstract to the concrete);

3) formal logical procedures - analysis and synthesis;

4) group methods that are used only in a particular group of sciences, for example, only in the social sciences (e.g., method of concrete sociological research);

5) special methods that are appropriate for the study of any science subject (interpretation of the legal norms, special techniques summarizing legal practice $)^{1}$.

Methodology is objectively determined by the subject knowledge derived from general conceptual approaches, the level of the scientific knowledge. The methodology is a system of methods, a set of techniquess and activities of research and knowledge about them. Objectively, this system is stipulated by the nature of the phenomena and processes which

${ }^{1}$ Юридична енциклопедія : В 6 т. / Редкол. : Ю.С. Шемшученко (голова редкол.) та ін. / 3-й том “К-М”. К. : Укр. енцикл., 2001. С. 618. 
are studied and which arise from the general methodological state of thescientific knowledge and scientific interests.

A comprehensive and detailed study of the methodological problems of environmental legislation development should be one of the main tasks of the science of environmental law. Methodology of environmental laws is an application of a set of specific theoretical principles, logical and special methods of investigation of the environmental legislation development ${ }^{2}$. The method of study is a mind process that is implemented in a scientific manner and focused on the subject (object) of the research to acquire new legal knowledge in general theoretical and in applied aspects of the study.

There are main methods of scientific research in environmental law:

1) formal logical method that provides scientific reliability of the obtained information and enables to detect inconsistency of certain environmental laws with the realities of social life, as well as contradictions between some norm-legislative acts;

2) formal legal method that guarantees the study of environmental law development problems exclusively in the context of positivism;

3) method of factor analysis, which allows to take into account quantitative and qualitative changes in environmental laws depending on certain circumstances, and also to build factor models needed in the process of legal forecasting;

4) functional legal method which requires the study of environmental law from the standpoint of its tasks and functions;

5) activity method that helps to examine the role, place and meaning of a single norm-legislative act in the environmental legislation;

6) comparative legal method which facilitates the identification of general and special, typical and unique characteristics in the legal regulation of the environmental relations in different countries. It allows establishing a positive experience of legal regulation of environmental relations abroad;

7) sociological method which enables to study and consider the general laws of social development, economic analysis, political, social, psychological, demographic and other phenomena in the society in the process of developing regulations of the environmental laws;

8) historical and legal method that provides succession of environmental laws development, allows to reveal the positive and

2 Гетьман А. Методологічні засади становлення правових основ охорони довкілля. Право України. 2011. № 2. С. 14. 
negative features of historical sources of environmental laws and helps to establish the consequences of their impact on the environmental relations;

9) systematic and structural method that allows to regard the environmental legislation as an orderly, coherent, logically structured set of normlegislative acts aimed at regulating land relations;

10) logical-semantic method based on tracing the formation of specific conceptual-categorical system of the environmental laws;

11) prognostic method that makes it possible to make science-based forecasts of the environmental laws development. Formal-logical method is one of the most traditional ones in the legal science ${ }^{3}$.

It requires from the researcher a certain order of study, consistency, credibility and accuracy. It is essential to follow formal-logical requirements to ensure the reliability of the received information. This method allows identifying the discrepancy between legislative norms and the realities of the social life, the contradiction between the acts, etc. It is necessary to consider the peculiarities of the application of the formal legal method while studdying the environmental law because of its usage has both advantages and disadvantages.

Studies of the environmental law developmental problems exclusively within the context of positivism can lead to a simplified view of the legal phenomenon because only the features of legal phenomena secured by the legislator could be deeply scientifically analysed using this method. Therefore formal legal method should be used only in combination with other special legal methods. Functional method requires the study of the law sources through their functions, several functions or functional system. The functional nature of the system of the law sources stipulates the methodological grounds of their study, namely, the need to study the activities of each component of the system, the interaction between them and other systems.

The system of law sources is dynamic; it is constantly evolving because of its inherent internal and external conflicts, operating in an external environment that defines and develops it, determines the direction of its operation. The method of functional legal analysis is important both for the general theoretical plane, and for the determination of the effectiveness of environmental law. This is the method of systematic study of the effectiveness of the environmental-legislative norms in the process

${ }^{3}$ Пархоменко Н. М. Джерела права: проблеми теорії та методології : монографія. К.: ТОВ “Вид-во “Юрид. думка”, 2008. С. 38. 
of its implementation, which considers the quality and the degree of the implementation of the functions specified in the legislative acts (legal norms) which regulate the environmental relationships.

The application of the functional legal method will help to orient in the legislative acts, practical materials of its implementation, will create favorable conditions for the development of scientifically based recommendations for the improvement of the environmental legislation and the mechanism of its application.

Activity method involves the study of law sources through their action. These techniques are linked, but not independent. Application of the activity method helps to identify the role, place and the importance of law sources in the legal system.

Comparative legal method helps to take into account existing international experience, models of organization and functioning of the environmental sources, individual norm-legislative acts, analysis of the legal comprehension concept. Comparative legal method is used to determine common and different features of the law sources within one or more legal systems, by comparison, discrimination on any ground or characteristics. The decision of Ukraine to enter the European space requires adapting of the EU legislation, which in its turn makes it mandatory to use the comparative method of the research ${ }^{4}$.

Comparative legal studies are rather useful for the implementation of legal reform in the states that are at the transformation stage of their development (such as Ukraine), as it enables to go beyond dogmatic debate within the national law and to offer new methodological approaches, taking into account national experiences. Special methods of comparative legal research are represented by compare (based on similar material properties of objects) and contrast (standard selection among objects, which can be the most effective model of regulation in specific circumstances).

Critical method makes it possible to assess the specific provisions regarding the prospects and trends of the environmental legislation development that allows to reconsider earlier developed theoretical construction in a new way, to get rid of the outdated approaches and to detect errors in the doctrinal arguments of some scholars.

\footnotetext{
${ }^{4}$ Малишева Н. Р. Гармонізація екологічного законодавства в Свропі : дис. у формі наук. доповіді на здобуття наук. ступеня д-ра юрид. наук; Ін-т держави і права ім. В. М. Корецького НАН України. К., 1996. С. 18.
} 
System-structural method integrates systemic analysis and structural functionalism. It represents two aspects of a systematic approach to the analysis of the operation and development of the law sources. Systemattic analysis is essential for the study of law sources and is stipulated by the imposed problem itself. The system of law sources in some way requires an orderly, coherent, logically constructed set of the law sources.

The usage of this method allows to find and fully analyze the mutual influence of the law sources, to draw a conclusion about the effectiveness or ineffectiveness of the functioning of the law sources system in general and in Ukraine in particular. Predictive method is a set of techniques that allow to make scientifically-based predictions about the future development of law sources. A separate aspect of the research methodology of the law sources is the relationship between the phases, stages, which has a hierarchical character, namely: each next consequent stage uses materials, knowledge gained at the previous stages, despite the fact that the basis of the analysis is only objectively-true knowledge, this relationship between stages leads to the hierarchical relationship between the methods used at these stages.

Science which is based on a certain set of concepts of various sciences is a methodologically properly structured science. It serves the basis for the true methodological law structure and allows to carry out a profound methodological analysis, to design a new methodological strategy based on co-evolutionary relationship between human and nature, anthropology, synergy and other modern sciences.

During the last century the classical methodology, built on rational and objective approach, through nonclassical (with its freedom of choice and subjectivity), came to the post-classical (postmodern) methodology, which is characterized by the recognition of irrational and pluralist approaches. The deidealization has replaced ideological standards that had prevailed in the national methodology for almost the entire twentieth century. That's why the greater ideological importance is focused on human values and respect for the principles of humanity, human dignity, freedom, justice, mutual responsibility of the state and the individual. Till now the dominant ideological monism has limited research by the dogma of law.

Future law science seems primarily responsible for studying two basic fundamental key problems: the methodology of law and cooperation with other natural, technical and social sciences. It's time to finally understand that the content of the development of methodological law problems doesn't only involve self-understanding of the science, the improvement 
of the legal culture of thinking, but it also gives the future research powerful cognitive tools that allow to deeply penetrate into the unknown, not yet investigated layers of the legal reality. An important methodological feature of the study of the environmental law is the usage of an interdisciplinary approach. The Environmental law as a science is a structured knowledge of the environmental norms, forms and methods of forming the environmental law awareness and ways to improve it. It also includes: legislators' ideas about the subject and method of the given branch of legal knowledge, sources and determinants of their formation, the place of environmental law in the jurisprudence.

The essential point that determines the nature and characteristics of the formation and development of the environmental legal knowledge is the awareness of the connection of environmental rights, not only with other branches of legal science, but also with other social sciences - sociology and philosophy that define the methodological research. In particular, the philosophical part is not only an external means of theoretical justification, but it also determines the methodological orientations and inner meaning of most theoretical concepts and the knowledge. National and foreign philosophical, economical, environmental, agricultural, biological and other doctrines, as well as the legal doctrine of the environmental usage are the basis for the economic, social, public legal, demographic, spiritual and cultural development of the people and conservation of the environment. In the relationship people - nature an exclusive role belongs to the environmental as an object of legal regulation of social relations are caused by its objective physical characteristics and functions in nature, economy, society, and the subjective legal qualities that define it as an object of environmental land law.

Environmental relations develop on the basis of the economic consequences, and the environmental laws influence their formation and development. While regulating with the help of the developed norms of the environmental legislation, the reverse process of transferring regulatory requirements into an actual behavior and into real social environmental relations.

Updating of the problems of using sociological approach in environmental law science is stipulated by the role of this area of law in theory and practice of state functioning. One of the real ways to overcome the crisis in modern jurisprudence is the development of the sociology of the law, the study of law as a phenomenon of our civilization through the prism of "life", abstract legal norms due to its application, fulfillment and 
realization by the subjects of the social relations. Environmental legislation as a specific regulation tool significantly affects the selection of means and methods used in the process of regulating environmental relations.

In a legal state the legislative activity involves correspondence between legality and law expediency taken on behalf of the state organized society. They necessarily take into account the interests of each individual, which are implemented by all legal entities and primarily by the state itself. Since the law as a whole is intended to assist the legislator in the development of scientific bases of society and sciencebased recommendations for the improvement of this administration, it can be argued that the task of legal science is to assist the legislator in the formulation and adoption of legal norms.

\section{Modern Approaches to Environmental Law Medology}

Nowadays environmental law is developing rapidly and the science of the environmental law should aim at facilitating this process by solving current and future problems of improving the environmental legislation. The social function of the legal science require scientists to develop effective mechanisms that can influence the situation in law enforcement. In order to adequately respond to the current need for integrated research of analytical and applied nature, it is necessary to turn theoretical understanding into the generalization of the social and judicial practices, considering the legislative dynamics and changing economic and political conditions.

This approach does not reduce the importance of the fundamental works. It primarily deals with the fundamental nature of the legal science, the attempt to close the gap between theory and practice. The Environmental law today is experiencing a period of the accumulation of the theoretical knowledge, but its isolation from the needs of the legal and social life may have negative consequences for the entire industry. Legislative activity is based on the needs of objective, independent from the people's will economic laws. Implementing the unification of the old and developing the new environmental legislation is necessary to take into account the objective nature of the economic laws, correlation between economic and legal laws question which leads to the subjective idealism.

The current level of the environmental law science and legislative activity poses before the science of the environmental law the problem of improving the methods of the empirical research in the field of 
environmental law norms application with the goal to identify their efficiency and find ways to improve environmental legislation, bringing it in compliance with the changing socio-economic conditions of our society. In this regard, considerable importance is attached to the sociological trend in land environmental science, which involves the study of actual social relations in environmental law, analysis of the relationship between legal norms, legal relationship and actual environmental relations. In particular, the methods of empirical research in environmental law represent surveys and questionnaires of environmental law specialists, observation method, etc.

The socialization of the law and legal knowledge has become one of the most important directions of adapting domestic law to the current challenges. The man as a carrier of inalienable rights and freedoms, which have to determine the content and direction of the state functioning, can now be seen outside the legal science ${ }^{5}$. Only with awareness of the social foundations of rights, the legislation may be considered in the context of ensuring and protecting the rights and freedoms of a man and a citizen, functioning of a legal state and a legal culture. On this basis the sociological approach to a law as a theoretical concept that has social nature, different from the usual application of the jurisprudence methods of empirical sociological research to confirm certain theoretical conclusions, is formed. It is necessary to conduct in-depth analysis of the existing environmental relations which require or may require the legislative regulation. Since actual social relations are rather interchangeable, unstable, it is important not only to identify their current system, but also to find out the trends of their development. This analysis makes it possible to build a model of legal regulation of relations in the future, or, in other words, to predict the development of the environmental law, to prepare the creation of appropriate norms and institutions.

The main peculiarity of a legal prediction is the recognition of the fact that the law is always evolving to reflect changes in social life, in actual people's relations. It is possible to predict the development of law only on the basis of known or projected society development. However, the prognostic nature of the reflection in the law has its limits which can be divided into social, epistemological and the legislative rights themselves.

5 Петришин О. Проблеми соціалізації права та соціологізації правової науки. Право Украӥни. 2011. № 8. С. 138. 
Social boundaries are expressed in the fact that the legislation should not only accurately reflect the future development of social relations, but also take into consideration a real social, specific historical opportunity to achieve it. Socio-legal prediction can be fruitful only when it is based on the study of the general laws of the social development. It is necessary to analyze the economic, political, social, psychological, demographic and other phenomena in society, which together determine the possibility of a public life regulation to reveal the objective laws of these phenomena ${ }^{6}$.

The fundamental methodological problem of environmental law and legislation is the subjective factor and the complexity of legislators' understanding of the legal environmental processes and phenomena. A man creates legislation that would adjust environmental relations, and it seems that the existence of this law depends on the will of a person who has made it. However, the trajectory of environmental legislation often goes beyond the goals and objectives of its creators. The environmental law science is beginning to use synergy methodology, a new science that studies self-organizing, random processes. These methodological ideas allow a better understanding of the genesis of the environmental legislation, some of its legal institutions.

Environmental relations are to be investigated according to the laws of self-organization and self-development. They have a historic status, stages of growth and development, periods of stability and change. Historical status of the environmental relations helps determine the specificity of different stages of formation and functioning because their development depends on the stages of the social development. The spread of synergy as an interdisciplinary research method marked the transition to Postclassical development of the science.

Synergetics explores various open systems capable of selfdevelopment. This system is estimated as a nonlinear, characterized by a special mechanism of bifurcations, irreversibility and uncertainty. Random fluctuations imbalance the system and as a result, it loses its stability. Due to the positive feedback, the fluctuations are increasingly amplified and can lead to bifurcation - the destruction of the previous system and its transition to a new state. Switching to a higher stage means selforganization. Instability is no longer considered as something destructive

\footnotetext{
${ }^{6}$ Костицький В.В. Соціологія права: науково-теоретична спадщина Свгена Ерліха і проблеми розвитку сучасної наукки: Монографія. Ін-т законодав. передбачень і прав. експертизи. Вид. 2-ге. Київ : Коло, 2016. С. 87.
} 
and negative; it is regarded as a condition of stable and dynamic development. The emergence and development of the idea of the imbalance, non-linearity and instability proved multivariate ways of development ${ }^{7}$.

As a result, modern system of thinking is more likely to take into account the dynamics in the study of stability problems. Synergetic understanding of the development and structure represents a new stage of methodology.

Productivity of synergy ideas is the synthesis of the subjective and objective approaches. The role of synergy provokes internal growth, selforganization of the environmental and legal knowledge, its inner reorganization. New information about the constructive role of a chance in a social development allows to clarify the subjective factor of reforms, and to take into account both logical cause-effect relations and random relations. Possibilities of synergy are extremely broad in the study of legal processes.

Synergistic methodology is relevant due to the increase of the number of the regulations, widening of the range of their action and consolidation of them with the disparate, sometimes contradictory public interests. Synergistic methodology develops the concept of selforganization rights, emphasizing the growing danger of the disruption. It points out the cause of unpredictable reactions of subjects in their legal relationship. Synergetic approach allows us to take a fresh look at the issues of overcoming and eliminating inconsistencies in the regulations and other legal acts. The research is driven largely by the structural and systemic approach. The specificity of synergetic approach lies in its completion by a large unit that examines patterns of inconsistency of the law. In addition, scientific approach using synergy ideas enables us to master qualitatively a new group of methods and principles of the research.

Synergistic research approach to legal theory leads to the conclusion that the synergistic ideas can help "uncover" significant resources for improving the efficiency of the regulation without any special costs and, what it is important, to minimize the costs of limited legal means and methods. On the way of the promotion of new ideas in law, the legal science should reject the domination of the monistic law comprehension. Its roots are so deep that many researchers ignore the fact, and some

7 Князева Е.Н. Синергетика: начала нелинейного мышления. Общественные науки и современность. 1993. № 2. С. 13. 
directly deny any other spheres of law life except legal norms based on the traditions of "pure" law. This leads to a conclusion about the excellency of the standards established by the legislator, where judgments are made within the space, limited by the regulatory forms ${ }^{8}$.

The necessity of transcending law dogma and consideration of its other faces and forms of existence is dictated by the objective needs of the environmental law as a branch of law, and as a science. This dogmatic approach is not rejected, but it must be used in the combination with other approaches, such as natural, social and others. Only then environmental legislation will be available for public understanding as a regulator of environmental relations.

The value of the current environmental law and its highest purpose is to create conditions for the realization of the natural and inalienable environmental rights. Environmental issues should be investigated according to the laws of selforganization and self-development. They have historic status, stages of growth and development, periods of stability and change. Historical status of environmental relations helps determine the specificity of different stages of formation and functioning, because their development depends on the stages of social development.

Ukraine has rich nature, which can be a strong base for the solution of socio-economic problems in the country. That's why today the most acute problems are concentrated in the sphere of the environmental and land relations. Instead of the long absence of the variety of forms of the possession the process of the development and implementation came with the equality of the land ownership. During the transition period the main emphasis in the theory and practice lies on the recognition of the necessity of the private ownership of land and the formation of a new stratum of landowners. However, the transformation of land relations, along with the positive effect of the development of different forms of land ownership, have found some dangerous trends in the national economy, which ignore the role of the state. Acute problems of the irrational land usage, the question of the land taxation, regulation of land relations in a market economy pose new methodological, conceptual and theoretical research tasks in the field of the land policy. Under the new conditions, modern Ukraine needs complete and effective land relations, formation and regulation of which are the purpose of land legislation.

${ }^{8}$ Сидор В.Д. Методологічні основи земельного законодавства України. Наукові записки Львівського університету бізнесу та права. Львів : ЛУБП, 2010. Вип. 5. C. 168 . 
The concept of the objective and tasks of the environmental legislation and law are sometimes are clumped together. It is necessary to compare these concepts and to determine the place of each of them in the environmental legislation and law, as well as implications of their development. Furthermore, in the absence of a clear, systematic understanding of the objective and tasks of the current environmental legislation and law it is important to analyze the existing definition of the objective and tasks, to give their classification and suggest precise formulation for further development of the environmental laws. This study is becoming outmost important against the general background of the legislators' decreasing interest to clarify the objective and to set tasks. It is known that the objective shows the value and meaning of the existence of the legal means and focuses on the values that underlie the legal policy of a particular state.

Outlining the scope of freedom of behavior of the environmental relations, the mechanism of environmental legislation and law gives a possibility to differentiate and integrate a variety of interests in environmental purchase and the usage of their useful properties which are formed in a society; to resolve in a civilized way environmental disputes, to find compromise in the process of solving conflicts. This is the general social essence of the environmental law - on one hand, while establishing the basic law of the environmental rights and freedoms, the government gives a possibility to act, and on the other - restricts the freedom of the individual, setting the rules of proper (or, conversely, improper) behavior.

The rights of citizens determine the meaning, content and application of the laws, the activities of the legislative and executive authorities, local authorities and provide justice. The constitutional duty of the legislative, executive and judicial authorities to respect and ensure respect for human civil rights is one of the most important legal principles to protect them. Environmental and legal rules are aimed to create intolerance for violators of the environmental law, increase respect for nature and its resources. Environmental legislation establishs behavior standards and attributs or prohibits certain actions, contributes to public justice. The correlation of the objective and tasks of environmental laws and rights lies in the secondary character of tasks as to the purpose because tasks are defined by and subject to objective laws of the nature. The task of the environmental legislation and laws is one of the varieties of social problems of society. Such tasks are aimed to achieve the goal of the legal regulation of the environmental relations. 
Prerequisite for the development of the environmental legislation is the study of the effectiveness of its regulations. The problem of improving the environmental legislation at present is of particular importance, due to the great difficulty towards democracy and development of the law. Hence the urgency is the research directions of the environmental legislation of Ukraine, establishing its constitutional provisions and other conditions of formation of the law, the development of the legal principles and structures to ensure the stability of the environmental policy and legal protection of human and civil rights. The legal regulation of the public environmental law plays an important role in this. Creating laws and regulations regarding the use and protection of nature, the state establishes universal rules of conduct and ensure their implementation, brings order and organization in the society, replacing outdated environmental public relations, improving existing and developing new ones. As a result of the legislative activities of the state normative and organizational and legal guarantees of rights are created, on which the establishment of law and order in the land sector largely depends on.

The concept of efficiency of the environmental legislation can be seen as a set of features that characterize the formal legal perfection of the environmental regulations, as well as properties that contribute to the most optimal regulation of the environmental relations according to the purpose and functions. The effectiveness of the legislation is interpreted in the legal literature as the ratio between actual results achieved and the purposes for the achievement of which the relevant legal rules were adapted. The purpose of the legal norm is defined by the measurement of the efficiency that can be applied in the environmental law while studying its effectiveness. Exploring the effectiveness of the legislation can be studied as an internal quality of the legal decisions and their impact on the social relations.

The standard evaluation of the legal norms is the purpose of the norm, since objective standards accumulate social interests, compliance with norms of the social needs, their relationship to other rules of law. The problem now is the inefficiency, imperfection of the mechanism to ensure citizens' rights to nature objects. The ability of the legislation during its operation and development to create the conditions for maximum satisfaction of the basic needs and human interests has been reflected in the notion of the social essence of the legislation. According to the social purpose legal norms are designed to ensure recognized by the society and law, which are expressed in the Constitution of the state and other sources 
of freedom, equality and justice of a person, team and the people in the guaranteed by the Constitution of Ukraine rights and responsibilities regarding the use of the natural objects to meet private and public needs and interests.

This environmental legislation of Ukraine does not exclude the possibility of natural rights to the natural objects, if such rights for various reasons have not been legislated, but their implementation is recognized by the society and are not contrary to the laws of the state and the rule of the supremacy of the law. Therefore, the quality and efficiency of the environmental legislation of Ukraine is largely dependent on how fully and timely state ensures the natural rights of certain subjects on the natural objects, provides equal and fair conditions for the implementation and protection of such rights by establishing them in the legislative norms.

An important problem is the efficiency of the regulations of the environmental legislation. It requires a higher level of the quality of their implementation and the existence of the consistent mechanisms to ensure existing regulations. The task of the quality drafting of the new regulations of the environmental legislation becomes of the great importance. After all, how effectively adopted legal act affects the regulation and development of the public relations, primarily depends on the quality of the content of its specific provisions formulation of which mainly occurs during the development of a legal act.

In the environmental law the determination of the effectiveness of the environmental law is particularly important because of the complexity of the regulated relations. Given that the regulation of the environmental relations is the establishment of a certain behavior of their object - the earth, one of the effectiveness indicators of the environmental law may also be a qualitative state of the object, and in some cases it depends on the requirements stipulated by the environmental legal norms. Therefore, the state of the object itself may indicate an achievement or failure of reaching the goal of the legal norms.

Efficiency of the environmental legislation of Ukraine depends on a set of conditions, required not only by the quantitative, but primarily by the qualitative approach to reform the environmental laws of Ukraine to improve its efficiency. The effectiveness of the legal regulation of the environmental relations is of great social importance. The main criterion of the efficiency of the environmental legislation is the extent of current environmental and legal norms guarantying the rational usage and complex protection of natural objects. 
Efficiency of the environmental legislation of Ukraine is largely dependent on the continued improvement of the environmental law. Various legislative performance criterias are developed in the legal literature. The basic criterion of effectiveness is reaching the goal of the legal regulation, it can be called the result of the regulation. This result is dependent on the object of regulation. There are economic and legal resulst of these actions.

Economic result of the regulation may be called objective because it reflects the economic viability of the law. Only those legal rules that meet the objective economic laws, can give the desired economic result in the process of the regulation. Economic result of land legislative regulation depends primarily on the quality of the environmental laws and their proper application.

It should be noted that the use of economic criteria in evaluating the effectiveness of the environmental laws should be applied depending on whether the natural object is used as a means of production or as a spaceterritorial basis. An important criterion of the effectiveness of environmental legislative regulation is the legal result. It describes the impact of the regulation on the consciousness and behavior of the environmental relations participants in terms of precise and strict application of the law; shows how the resulting regulation strengthens the legitimacy of the area of environmental law or how the environmental law promotes justice for the participants of the environmental relations. The legal outcome of the legal regulation is related to the economic performance, because the favorable economic result is a proof of a positive effect of legal rules on the minds of the business relationships.

The criterion of the efficiency of the environmental legislation of Ukraine is the following qualitative state of the settled norm legislative regulations of environmental relations, that indicate that the goal of environmental legislation has been achieved. The evaluation of the effectiveness of the environmental legislation requires a comprehensive analysis of its formal and substantive legal issues. One of the criterias of an effective legal act as the main element of the legislation is its legal correctness that avoids inconsistencies of the environmental legislation and ensure its unity.

The high quality level of the environmental law is ensured by a number of factors that can be divided into material and specially legal. Tangible factors include sustainability of socio-economic and public policy linkages, timely legislative response to the critical processes taking into 
account the perspectives of the nature of their development, the objectivity and validity of the changes in the environmental relations, forecasting the need for their legal mediation in the future. Specially legal factors include correspondence of the environmental laws of the Constitution of Ukraine, publishing of the subordinate norm legislative acts based on the law, the perfection of the legislative technique, legally competent usage of the adopted legal act. In determining the efficiency is important to consider not even the goal of the laws, but the interests (whose interests the specific regulation is targeting). These issues must be fundamentally solved in the development of the regulation and have the necessary economic and legal justification.

The identification of the interest depends on the need to meet the needs of particular social groups, classes or individual segments of the population and the possibility to meet these needs through activities of these entities, which is a model, the main components of which can be regarded as the most important elements of performance:

- social needs, which are attempted to meet by a particular regulation;

- legal means, their quantity and quality;

- their ability to meet social and legal means necessary confirmed in the normative act;

- the future directions of the improvement of the legislation in order to meet social needs through legal means.

The main criteria of the project quality regulations are:

- compliance with the provisions of the draft of the Constitution of Ukraine and the regulations of a higher power, compliance with the requirements of the draft of the international legal acts ratified by Ukraine;

- inadmissibility of a restriction or violation of the provisions of the draft of the legal rights of man and citizen, conformity of the draft objectives and the goal to achieve;

- the absence of contradictions between the project fundamentals and the related norm legislative acts of the same legislative power;

- the correspondence of the legal form, which is expected to enforce the implamentation of the project, to the value of the public relations in the settlement;

- forecasting of the real legislative mechanism to ensure effective legal creation of the emerging acts.

Systematic analysis of the environmental legislation of Ukraine, based on the study of legal acts regulating the environmental relations, assessing 
the existing scientific approaches and concepts, enabling to assess the significance of various factors of the determined system of environmental laws, their interrelationships, determining the priorities of the industry legislation makes it possible to prepare a set of recommendations for improving the efficiency of the environmental legislation of Ukraine. Efficiency of environmental laws means matching the result of their influence and goal to the objectives of the environmental legislation.

The criterion of the efficiency of the environmental legislation is a qualitative state governed by the regulations of the environmental relations, that indicate that the goal of the environmental legislation is achieved. To improve the efficiency of the environmental laws necessary informed scientific advice based on relevant empirical studies are needed. It is important to improve the system of natural object usage and the legislation to ensure its implementation. Of particular importance is the question of the improvement of state control over the environmental usage and protection. Interests to improve the environmental laws require improvement of the courts and prosecutors' activities implementing of the environmental law, civil law, administrative law and criminal sanctions in case of violations of the environmental legislation.

Promising trend to improve the environmental law efficiency is to improve the law enforcement practices that should be done by the introduction of environmental law procedural norms, which ensure the proper application of the law in practice; to introduce the economic incentive measures for the proper performance of the subjects of the environmental relations duties.

Research of the legal factors of the effectiveness of the legislation is related to the necessity to analyze such theoretical issues as the legal consolidation of the dominant society's needs:

- certainty of substantive lawmaking authority;

- certainty of limits of the legal regulation;

- dependence of the lawmaking activity on the objective conditions of the society development;

- change of the scope and type of the regulation;

- peculiarities of the lawmaking as a result of the creative process;

- the systematic nature of the legislation;

- the quality of the legislation; perfection of the legal technique;

- clear definitions of the types of legal liability following the violation of the regulatory requirements, the mechanism of their implementation. 
The subjective certainty of the regulation directly affects its legal effectiveness. The effectiveness of the hierarchical structure of the legislation depends on the subjective characteristics of the society relations, consistency of the acts that compose it, and identification of the trends and tendencies of its development. One of the most important tasks of lawmaking in the usage and protection of natural objects is passing the laws of the high legal quality. Today, however, the quantitative parameters of the environmental legislation precede over the quality. The basis of updated environmental laws should be qualitative laws, so you need scientific support in the process of the lawmaking of the environmental legislation. The problem of ensuring of the the legal quality of laws is directly related to the task of providing reliable legal protection of persons in the area of the environment.

Various defects of the environmental laws reduce their effectiveness and provoke law enforcement errors that are often expressed in the violation of the environmental rights. The quality of the environmental laws is a stable set of qualities of the instrumentally legal, technical and legal characteristics of certain laws, all of which create the prerequisites for the effective environmental legislation in accordance with its goals and objectives. The quality level of the environmental laws can be determined as a result of the analysis of the degree of compliance with the claims of legal technique to create acts of environmental; giving the participants of environmental relations means of the legal protection of the environmental rights; the establishment of the mechanism of the implementation of the prescriptions of the environmental legislation; the quality of the legislative regulation of the jurisdictional legal means.

The effectiveness of the provisions of the environmental legislation under legislative activities can be defined by: the compliance with the rules of the legal technique in the process of the law-making and consistency of the environmental norms in the acts of the environmental legislation and other branches of the law, compliance with the present standards and the development of the social relations, which lay the legal prescriptions of the mechanisms that could actually function in a market economy. The effectiveness of the legislation depends not only on subjective but also on objective factors. For their acceptance the study of existing relations must precede the implementation of any acts, the possibility of their regulation by the laws, and the right choice of the most perfect forms of it. 
To comply with the legislation the following objective factors are needed:

- to explore various social factors that contribute to the legal regulation of the correspondent relations;

- to identify and take into account interests of social formations while developing the acts;

- the usage of the appropriate scientific achievements;

- a performance of the comparative analysis of the act with similar regulations of other states.

It must be noted that the law-making bodies in their activities do not always focus on the existing system of the environmental legislation of Ukraine. As a result, they have passed new environmental laws, which are inconsistent sometimes with current and may contain conflicting legal requirements.

Imperfection of some separate legal structures and, as a result, law enforcement practices, generate flaws that distort the overall substantial load regulations that establish mechanisms for the usage and protection of nature in Ukraine. Implementing of a strategically motivated, balanced legislative activity is impossible without a country-wide comprehensive analysis of the environmental relations, efficiency of the environmental laws and their application on practice. Modern attitudes to the current environmental laws at all levels of government and society can be described as the perception of an extremely complex, contradictory, incomplete and unsystematic array of laws that do not meet social needs, legislator's designs, and most importantly, the expectations of the citizens.

In connection with this objective it is necessary to create in Ukraine a complex mechanism of the current environmental legislation assessment and its compliance with the interests and objectives of the society and the state. To reduce the extent of the imbalance of the mechanisms of adopting and implementing of the environmental legislative decisions the monitoring system of environmental laws and law enforcement practices is created. It is necessary as a tool for evaluating the effectiveness of the reforms as a mechanism that facilitates timely response to the inadequate regulation of the environmental relations and problems of the law enforcement.

The monitoring of the environmental legislation has become a necessary element of the law-making authorities in order to analyze, control and improve the environmental legislation to bring it into conformity with the provisions of the Constitution of Ukraine. In this 
regard, monitoring of the environmental legislation is seen as a systematic, integrated activity of public authorities, the scientific community, civil society and community organizations for assessment, analysis, synthesis and prediction of the environmental laws and practice. The purpose of the monitoring is to improve the quality of the legislation in the field of regulations of the environmental relations, the improvement based on legislative and enforcement activities of the adoption and implementation of the environmental legislative decisions, respect for and protection of the environmental rights of the citizens. Application of the monitoringof the environmental laws will favor a timely elimination of the outdated rules and regulations, adaption of the amendments to existing regulations and so on. To increase the efficiency of the monitoring of the environmental laws will allow the development of a common methodological basis for the monitoring of the development of scientifically based indicators of the monitoring of the environmental legislation, active usage of the monitoring capabilities of scientific organizations, active usage of the international experience and so on.

In our opinion, the practice of the monitoring of the environmental legislation should expand the range of research methods - the study of documents, comparative analysis, statistical analysis, polls, method of legal expertise, experiment more. But currently studying of the documents and comparative analysis are seen as preferred methods. The monitoring system of the environmental laws should contain the necessary information about the development of the environmental legislation of EU and other foreign countries in terms of the usage of their positive experience. The monitoring system should include: thesaurus of the basic concepts and definitions used in the acts of the environmental laws; framework of the correspondent laws and acts applicable to the regulations; draft laws and subordinate acts that are under development and adoption; the database of the state enforcement activities with regard to judicial and administrative practice of the environmental legislation.

\section{CONCLUSIONS}

At present time there is an objective need for a comprehensive, systematic approach to the legal institution of the monitoring of the environmental legislation. Monitoring in the field of the environmental legislation is an innovative institution of governance and the development of the civil society. Based on the synthesis and analysis of its results the decisions in the sphere of environmental relations can be developed 
promptly, efficiently and effectively implemented. The establishment of a system for monitoring of the environmental laws is a necessary tool to ensure a proper quality of the government decisions on the basis of the development and consolidation of the experience that is already in the monitoring legislation. The creation and development of its new branch forms should be aimed to ensure the development and adoption of the common decisions by the legislative and executive powers in the process of the legislative activity.

Activation of lawmaking, as observed in recent years, along with its positive moments, adversely affected the structural organization of the modern environmental legislation of Ukraine. It does not ensured strict adherence to the principles of the system of the environmental laws, which leads to disruption of its internal logic. There have been numerous violations of the constitutional procedure of the adoption of laws and regulations, legal technology. The preparation of the norm legislative acts is mainly based on the intuition and personal experience of developers, rather than strictly established uniform rules or clear, science-based rules. This approach leads to deficiencies in the rule-making activity, which sometimes can not be fully corrected while adapting norm legislative acts.

\section{SUMMARY}

The paper is devoted to comprehensive and detailed study of the methodological problems of environmental law and legislation. The author substantiates that environmental legislation as a specific regulation tool significantly affects the selection of means and methods used in the process of regulating environmental relations. The system of approaches and methods in environmental law and legislation is analized. The paper emphasizes on such an important methodological feature of the study of the environmental law as the usage of an interdisciplinary approach. To author's opinion the socialization of the environmental law has become one of the most important directions of adapting environmental legislation to modern challenges. It is proposed to design a new methodological strategy based on co-evolutionary relationship between human and nature, anthropology, synergy and other modern sciences. Main legal factors of the environmental legislation effectiveness are investigated. The author proves that various defects of the environmental laws reduce their effectiveness and provoke law enforcement errors that are often expressed in the violation of the environmental rights. 


\section{REFERENCES}

1. Юридична енциклопедія : В 6 т. / Редкол. : Ю. С. Шемшученко (голова редкол.) та ін. / 3-й том “К-М”. К. : Укр. енцикл., 2001. С. 618.

2. Гетьман А. Методологічні засади становлення правових основ охорони довкілля. Право України. 2011. № 2. С. 14.

3. Пархоменко Н. М. Джерела права: проблеми теорії та методології : монографія. К.: ТОВ “Вид-во "Юрид. думка", 2008. C. 38 .

4. Малишева Н. Р. Гармонізація екологічного законодавства в Європі : дис. у формі наук. доповіді на здобуття наук. ступеня д-ра юрид. наук; Ін-т держави і права ім. В. М. Корецького НАН України. К., 1996. С. 18.

5. Петришин О. Проблеми соціалізації права та соціологізації правової науки. Право України. 2011. № 8. С. 138.

6. Костицький В. В. Соціологія права: науково-теоретична спадщина Євгена Ерліха i проблеми розвитку сучасної науки: Монографія. Ін-т законодав. передбачень і прав. експертизи. Вид. 2-ге. Київ: Коло, 2016. С. 87.

7. Князева Е. Н. Синергетика: начала нелинейного мышления. Общественнье науки и современность. 1993. № 2. С. 13.

8. Сидор В. Д. Методологічні основи земельного законодавства України. Наукові записки Львівського університету бізнесу та права. Львів: ЛУБП, 2010. Вип. 5. С. 168.

\section{Information about the authors:} Sydor V. D., Doctor of Law, Professor at the Department of Constitutional, Administrative and International Law, Kyiv Institute of Intellectual Property and Law, National University “Odesa Law Academy”

Kostytska I. O.,

Candidate of Law Sciences, Senior Researcher, Deputy Head of the Department of the Institute of Legislation of the Verkhovna Rada of Ukraine ORCID: 0000-0003-2336-1426 
Publishing house "Liha-Pres"

9 Kastelivka str., Lviv, 79012, Ukraine 44 Lubicka str., Torun, 87-100, Poland

Printed by the publishing house "Liha-Pres"

Passed for printing: January 17, 2020.

A run of 150 copies. 